\begin{tabular}{|c|c|c|c|c|c|c|c|c|}
\hline \multicolumn{3}{|c|}{$\begin{array}{l}\text { 2. To: (Receiving Organization) } \\
\text { Plant Support Operations }\end{array}$} & \multicolumn{2}{|c|}{ 3. From: (Originating Organization) } & \multicolumn{4}{|c|}{$\begin{array}{l}\text { 4. Related EDT No.: } \\
\text { N/A }\end{array}$} \\
\hline \multicolumn{2}{|c|}{ 5. Proj./Prog./Dept./Div.: } & Sv. & \multicolumn{2}{|c|}{$\begin{array}{l}\text { 6. Design Authority/Design Agent/Cog. Engr.: } \\
\text { A. R. Tedeschi. }\end{array}$} & \multicolumn{4}{|c|}{$\begin{array}{l}\text { 7. Purchase Order No.: } \\
\text { N/A } \\
\end{array}$} \\
\hline \multirow{3}{*}{\multicolumn{5}{|c|}{$\begin{array}{l}\text { 8. Originator Remarks: } \\
\text { Issued for Approval and Release }\end{array}$}} & \multicolumn{4}{|c|}{$\begin{array}{l}\text { 9. Equip./Component No.: } \\
\text { N/A }\end{array}$} \\
\hline & & & & & \multicolumn{4}{|c|}{$\begin{array}{l}\text { 10. System/Bldg./Facility: } \\
\text { Tank Earm/Piping }\end{array}$} \\
\hline & & & & & \multirow{2}{*}{\multicolumn{4}{|c|}{$\begin{array}{l}\text { 12. Major Assm. Dwg. No.: } \\
\text { N/A }\end{array}$}} \\
\hline \multirow{3}{*}{\multicolumn{2}{|c|}{$\begin{array}{l}\text { 11. Receiver Remarks: } \\
\text { N/A }\end{array}$}} & \multirow{3}{*}{\multicolumn{3}{|c|}{ 11A. Design Baseline Document? $\square$ Yes $\square$ No }} & & & & \\
\hline & & & & & \multicolumn{4}{|c|}{$\begin{array}{l}\text { 13. Permit/Permit Application No.: } \\
\text { N/A }\end{array}$} \\
\hline & & & & & \multicolumn{4}{|c|}{$\begin{array}{l}\text { 14. Required Response Date: } \\
\text { N/A }\end{array}$} \\
\hline \multicolumn{2}{|l|}{15.} & \multicolumn{3}{|c|}{ DATA TRANSMITTED } & $(F)$ & (G) & $(H)$ & (I) \\
\hline $\begin{array}{l}\text { (A) } \\
\text { Item } \\
\text { No. }\end{array}$ & (B) Document/Drawing No. & $\begin{array}{l}\text { (C) Sheet } \\
\text { No. }\end{array}$ & (D) Rev. & (E) Title or Description of Data Transmitted & $\begin{array}{l}\text { Approval } \\
\text { Desig- } \\
\text { nator }\end{array}$ & $\begin{array}{l}\text { Reason } \\
\text { for Trans- } \\
\text { mittal }\end{array}$ & $\begin{array}{l}\text { Origi- } \\
\text { nator } \\
\text { Dispo- } \\
\text { stion }\end{array}$ & $\begin{array}{l}\text { Receiv- } \\
\text { er } \\
\text { Dispo- } \\
\text { sition }\end{array}$ \\
\hline \multirow[t]{3}{*}{1} & $R P P-6759$ & $N / A$ & 0 & Determination of Secondary & $N / A$ & 1 & 1 & - \\
\hline & & & & Encasement Pipe Design & & & & \\
\hline & & & & Pressure & & & & \\
\hline & & & & & & & & \\
\hline & & & & & & & & \\
\hline & & & & & & & & \\
\hline & & & & & & & & \\
\hline
\end{tabular}

\section{6.

\begin{tabular}{|c|l|}
\hline Approval Designator (F) & \\
\hline E, S, Q, D OR N/A & 1. Approval \\
(See'WHC-CM-3-5, & 2. Release \\
Sec. 12.7) & 3. Information
\end{tabular}

17.

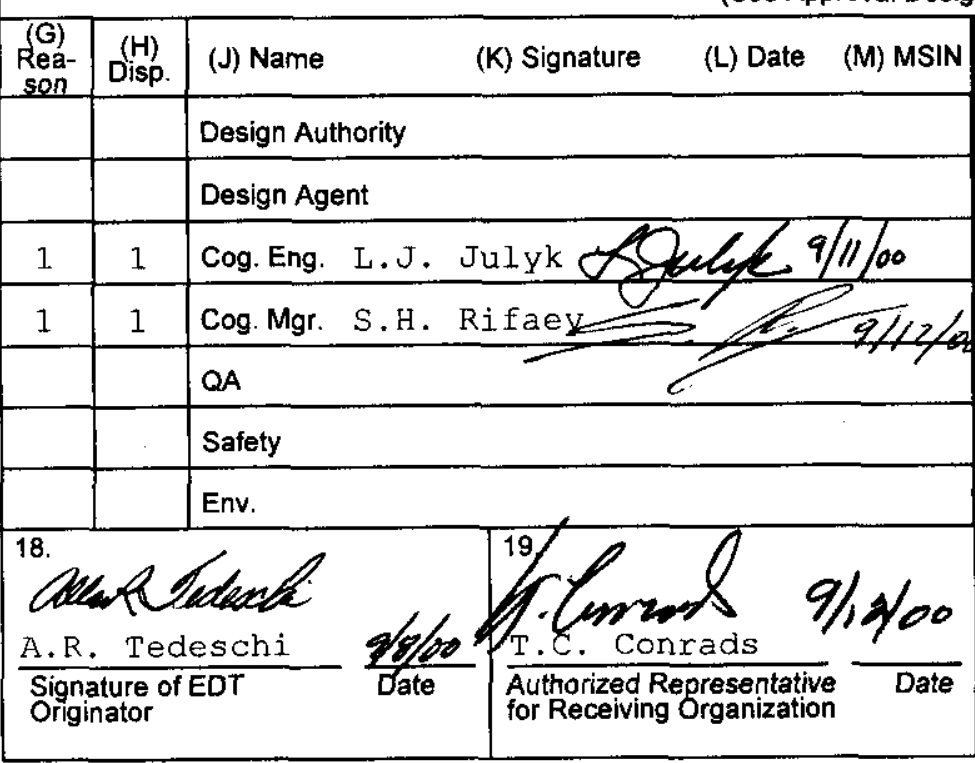

Reason for Transmittal (G)

4. Review
5. Post-Review
6. Dist. (Receipt Acknow. Required)

KEY

\section{Related EDT No. \\ $\mathrm{N} / \mathrm{A}$ \\ $\mathrm{N} / \mathrm{A}$ \\ $N / A$ \\ 10. System/BIdg./Facility: \\ Tank Earm/Piping}

$\mathrm{N} / \mathrm{A}$

$\mathrm{N} / \mathrm{A}$

4. Required Response Date

Disposition (H) \& (I)
1. Approved

Appomment

3. Disapproved w/comment
4. Reviewed no/comment 5. Reviewed w/comment 6. Receipt acknowledged SIGNATURE/DISTRIBUTION

(See Approval Designator for required signatures)
(1)

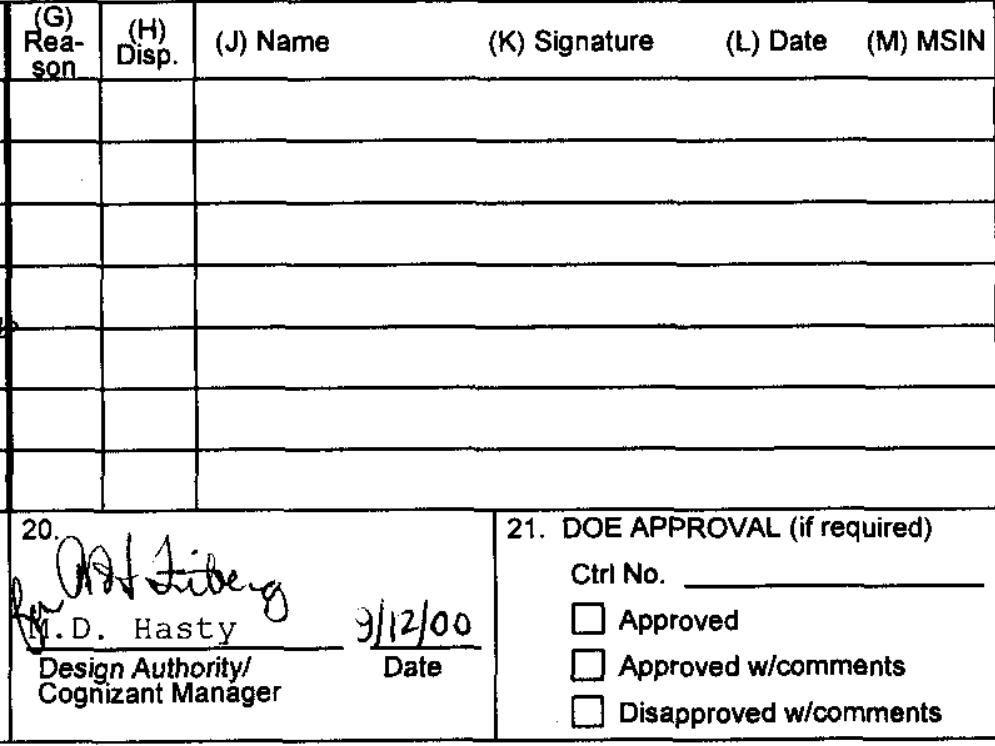




\section{DISTRIBUTION SHEET}

To

Distribution

Project Title/Work Order

River Protection Project/ RPP-6759

"Determination of Secondary Encasement Pipe Design Pressure"

Name

J. J. Badden

T. J. Conrads (2)

A. H. Friberg

E. R. Hamm

M. D. Hasty

L. J. Julyk

T. C. Oten

R. S. Popielarczyk

S. H. Rifaey

R. L. Schlosser

A. R. Tedeschi

\section{From}

A. R. Tedeschi

I

MSIN

T 4-08

R3-73

R3-83

$\mathrm{R} 1-31$

S7 -83

R3-83

S5-05

R3-73

T4-07

R3-47

R2-31
Page 1 of 1

Date September 11, 2000

EDT No. 629688

ECN No. N/A

Text

With All

Attach.

Text Only

Attach./

Appendix Only

EDT/ECN

Only

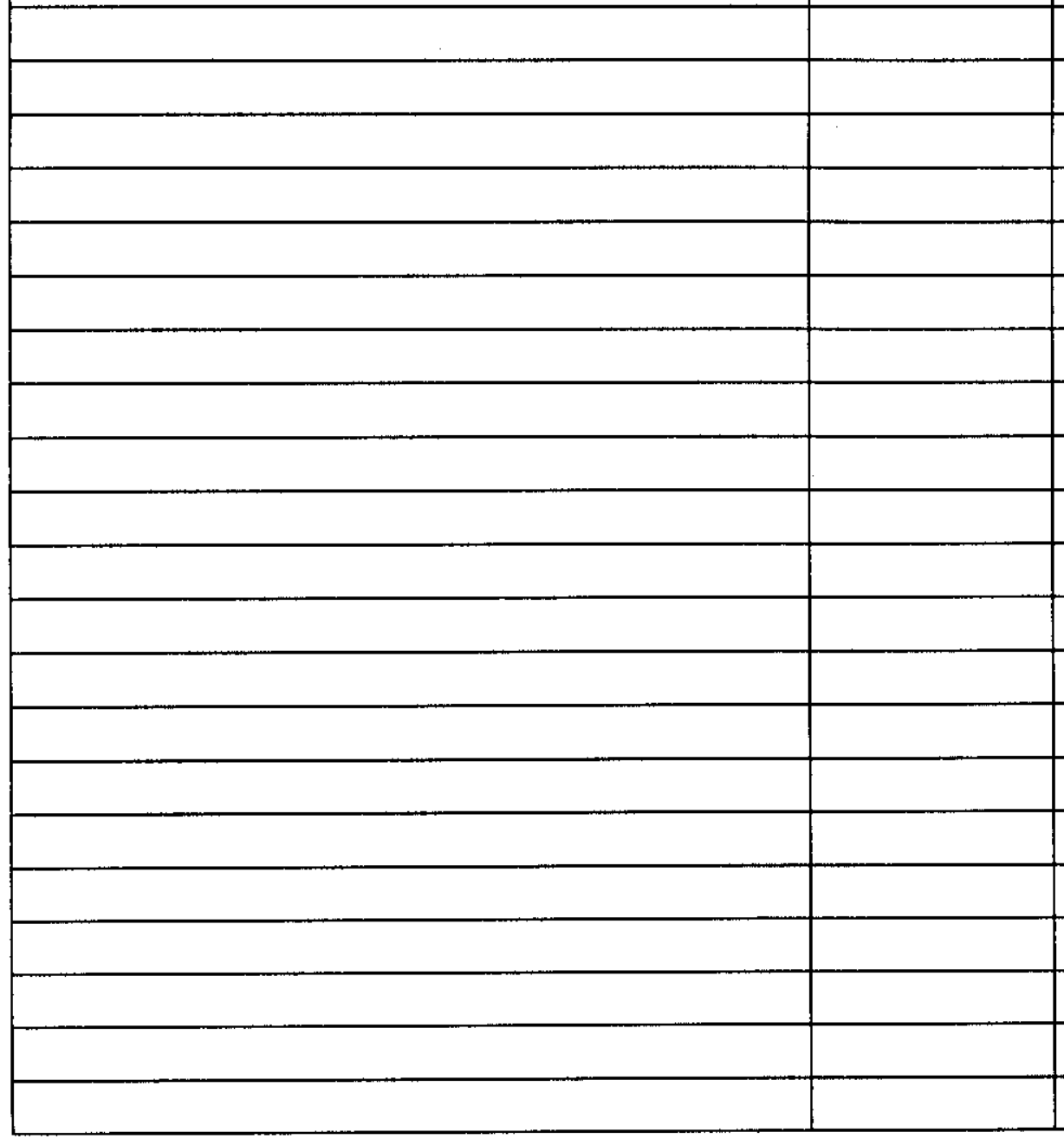

\begin{tabular}{|l|l|}
\hline & $x$ \\
\hline & \\
\hline & \\
\hline & \\
\hline & \\
\hline & \\
\hline & \\
\hline & \\
\hline
\end{tabular}




\title{
Determination of Secondary Encasement Pipe Design Pressure
}

\author{
A. R. Tedeschi \\ CH2M HILL Hanford Group, Inc. \\ Richland, WA 99352 \\ U.S. Department of Energy Contract DE-AC06-99RL14047
EDT/ECN: EDT $629688 \quad$ UC: 2030
Cost Center: 7M100 Charge Code:
B\&R Code: EW310010 Total Pages: $\mathbf{5 4}$

Key Words: double encased, encasement pipe pressure, tank farm

\begin{abstract}
This document published results of iterative calculations for maximum tank farm transfer secondary pipe (encasement) pressure upon failure of the primary pipe. The maximum pressure was calculated from a primary pipe guillotine break. Results show encasement pipeline design or testing pressures can be significantly lower than primary pipe pressure criteria.
\end{abstract}

TRADEMARK DISCLAIMER. Reference herein to any specific commercial product, process, or service by trade name, trademark, manufacturer, or otherwise, does not necessarily constitute or imply its endorsement, recommendation, or favoring by the United States Government or any agency thereof or its contractors or subcontractors.

Printed in the United States of America. To obtain copies of this document, contact: Document Control Services, P.O. Box 950, Mailstop H6-08, Richland WA 99352, Phone (509) 372-2420; Fax (509) 376-4989.
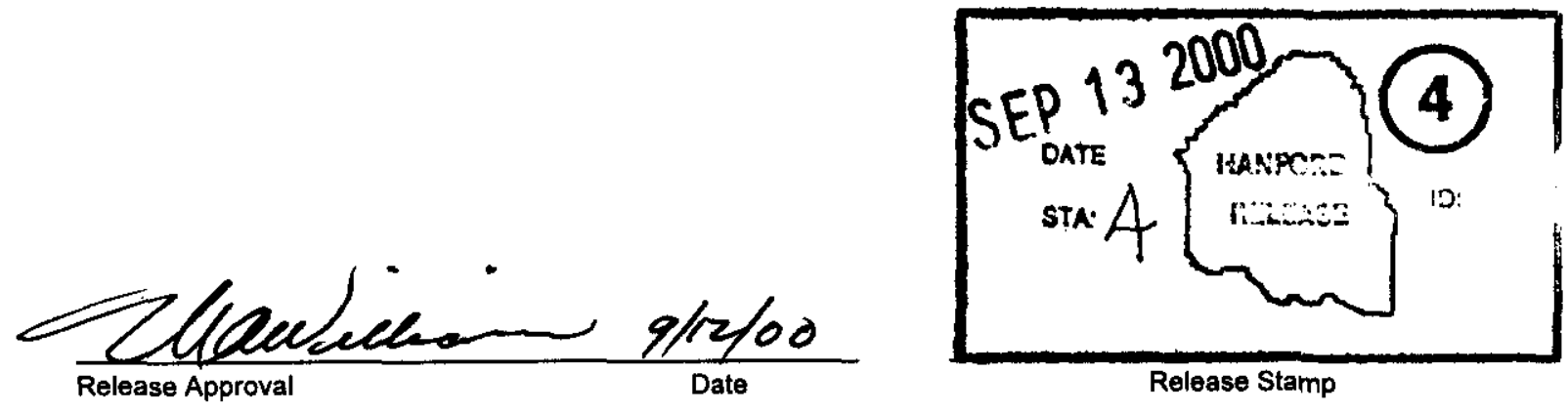

\section{Approved For Public Release}




\section{RECORD OF REVISION}

(2) Title

Determination of Secondary Encasement Pipe Design Pressure

\section{Change Control Record}

(3) Revision

0 RS
(4) Description of Change - Replace, Add, and Delete Pages

(7)

Initial Release
Authorized for Release

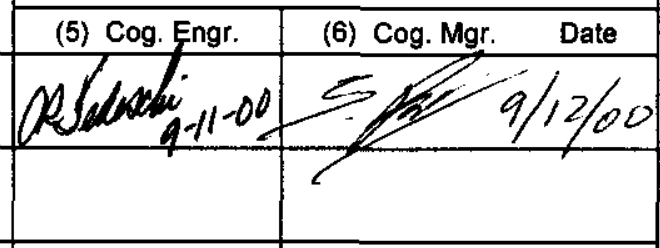


RPP-6759

Revision 0

\section{Determination of Secondary Encasement Pipe Design Pressure}

Prepared for the U.S. Department of Energy

Assistant Secretary for Environmental Management

\section{CH2MHILL Hanford Group, Inc.}

Richland, Washington

Contractor for the U.S. Department of Energy

Office of River Protection under Contract DE-AC06-99RL14047

Approved for Public Release; Further Dissemination Unlimited 
LEGAL DISCLAIMER

This report was prepared as an account of work sponsored by an agency of the United States Government. Neither the United States Government nor any agency thereof, nor any of their employees, nor any of their contractors, subcontractors or their employees, makes any warranty, express or implied, or assumes any legal liability or responsibility for the accuracy, completeness, or any third party's use or the results of such use of any information, apparatus, product, or process disclosed, or represents that its use would not infringe privately owned rights. Reference herein to any specific commercial product, process, or service by trade name, trademark, manufacturer, or otherwise, does not necessarily constitute or imply its endorsement, recommendation, or favoring by the United States Government or any agency thereof or its contractors or subcontractors. The views and opinions of authors expressed herein do not necessarily state or reflect those of the United States Government or any agency thereof.

This report has been reproduced from the best available copy. Available in paper copy and microfiche.

Available electronically at http://www.doe.gov/bridge. Available for a processing fee to the U.S. Department of Energy and its contractors, in paper, from:

U.S. Department of Energy

Office of Scientific and Technical Information

P.O. Box 62

Oak Ridge, TN 37831-0062

phone: $865-576-8401$

fax: 865-576-5728

email: reports@adonis.osti.gov(423) 576-8401

Available for sale to the public, in paper, from:

U.S. Department of Commerce

National Technical Information Service

5285 Port Royal Road

Springfield, VA 22161

Phone: 800-553-6847

fax: 703-605-6900

email: orders@ ntis.fedworld.gov

online ordering:

http://www.ntis.gov/ordering.htm 
RPP-6759

Revision 0

\section{Determination of Secondary Encasement Pipe Design Pressure}

Prepared by:

L. J. Julyk, T. C. Oten, S. H. Rifaey, A. R. Tedeschi

CH2M HILL Hanford Group, Incorporated

Date Published

September 2000

Prepared for the U.S. Department of Energy

Assistant Secretary for Environmental Management

\section{CH2MHILL \\ Hanford Group, Inc.}

P. O. Box 1500

Richland, Washington

Contractor for the U.S. Department of Energy
Office of River Protection under Contract DE-AC06-99RL14047

Approved for Public Release; Further Dissemination Unlimited 


\section{RPP-6759 REV 0}

This page intentionally left blank. 


\section{RPP-6759 REV 0}

Document Title: Determination of Secondary Encasement Pipe Design Pressure

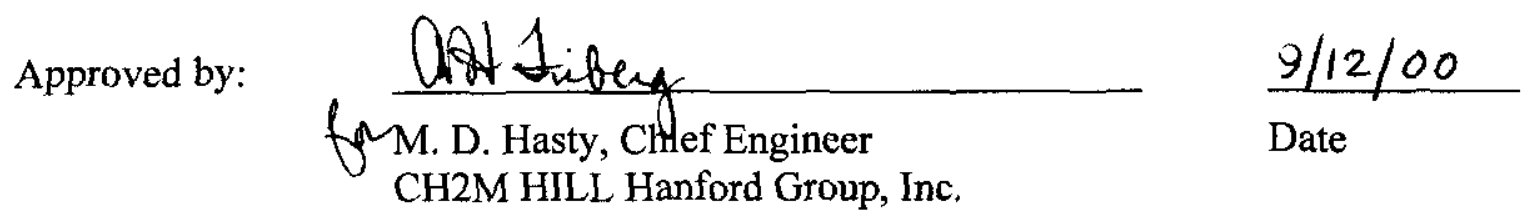


RPP-6759 REV 0

This page intentionally left blank. 
RPP-6759 REV 0

\section{EXECUTIVE SUMMARY}

This document, the Determination of Secondary Encasement Pipe Design Pressure, formally issues a calculation of the same subject. The calculation evaluated the maximum internal pressure experienced by the secondary encasement piping during a postulated worst-case primary pipe failure, for standard Tank Farm Contractor transfer piping. The largest encasement pressure calculated was 240 psig for a system with a low point 1 -inch diameter drain, and 170 psig for a system with a low point 2 -inch diameter drain. These values were calculated for the largest estimated Tank Farm Contractor piping section of 4000 equivalent feet, assuming a primary pipe operating pressure from a 650 psig dead-head pump with run-out flowrate of 285 gpm.

A significant reduction in the encasement pressure can be obtained if both a high and low point drain is provided. Under this condition the maximum encasement pressure was 140 psig with 1inch diameter drains and 40 psig with 2-inch diameter drains.

The resulting estimated encasement pressure is significantly below standard encasement design pressures, not using mechanical pressure relief. This evaluation may allow the lessening of design or testing pressure limits for future transfer piping. However, the estimated resistance loss factors for the pipe guides, supports, and anchors within the annulus flow region need to be verified. The short text in the body of this report summarizes the calculations, and the detailed calculations are included in the report Appendix. 
RPP-6759 REV 0

This page intentionally left blank. 


\section{RPP-6759 REV 0}

\section{CONTENTS}

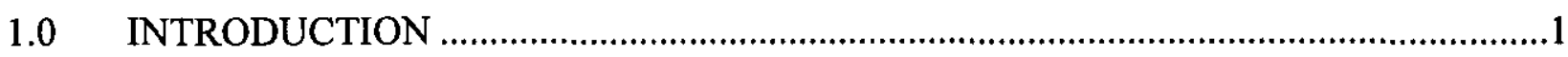

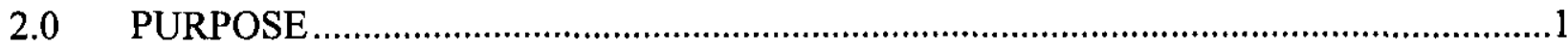

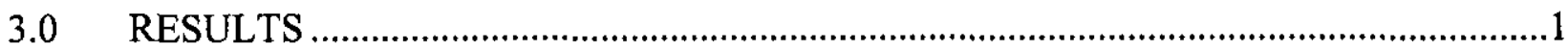

$4.0 \quad$ SYSTEM BACKGROUND......................................................................................

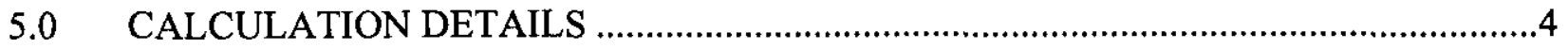

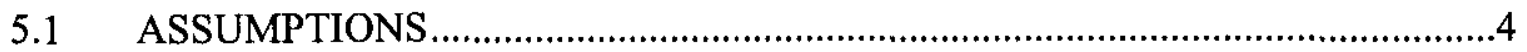

5.2 MODELING OF THE PIPE BREAK ………..................................................

5.2.1 Pipeline Failure ........................................................................................

5.2.2 Immediate Encasement Fill-up .................................................................5

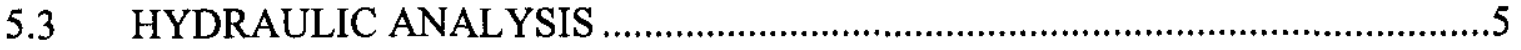

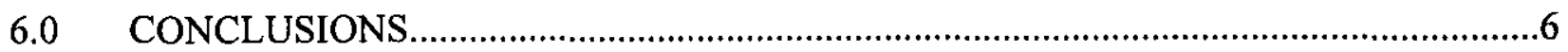

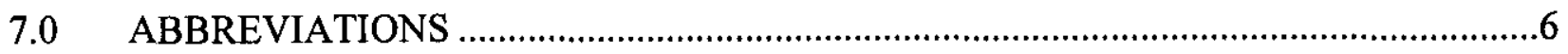

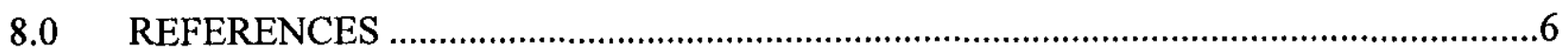

\section{APPENDICES}

A Detailed Calculation of Secondary Piping Encasement Pressure From Primary Pipe Failure

\section{FIGURES}

Figure 1. Double Encased Piping and Leak Detection ............................................................. 3

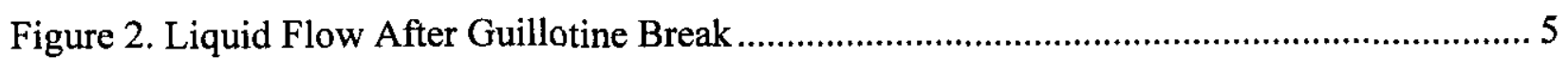

\section{TABLES}

Table 1. Maximum Encasement Pressure (psig) From Primary Pipe Break. 
RPP-6759 REV 0

This page intentionally left blank. 


\subsection{INTRODUCTION}

Mathematical evaluation of internal secondary encasement piping pressures was performed. Pressures were calculated for several primary piping break scenarios. This evaluation used standard flow and pressure formulas with conservative piping configuration and flow liquid assumptions. This document describes the evaluation results, calculation assumptions and details, and conclusions produced from the data.

\subsection{PURPOSE}

This evaluation will be used to assist development and modification of future functional design and testing criteria of secondary encasement piping. Currently, secondary encasement piping is designed, fabricated and tested to the pressure requirements of the primary piping. Secondary piping pressure requirements may be lowered by the optional usage of pressure relief or rupture disk relief systems. Project W-314 detailed these options in its transfer piping specifications (McGrew 1999a and 1999b). Primary and secondary piping for this project were to be both designed to $400 \mathrm{psig}$ while tie-in piping to the existing cross-site transfer line utilizes pressure relief. This design strategy is conservative but results in added costs that may not be warranted by worst-case flow and pressure scenarios. In addition to added costs, use of mechanical pressure relief of radioactive streams pose added risk to the environment and operator safety. In addition, encasement pressure testing during construction poses risk to testing personnel from the high air pressures involved, and their close contact needed for visual inspection. Results from this study may allow Design Authorities to reduce pressure requirements for encasement piping.

The results of this study are not applicable to the cross-site transfer line system because of differences in leak detection, transfer pump capacity, and the length of the line.

\subsection{RESULTS}

Three separate piping configurations were analyzed with different configurations of piping drains relative to the break point: 1.) Pipe sloping up from the pump with an encasement drain on either side of the break, 2.) Pipe sloping up from the pump with a single drain upstream of the break, and 3.) Pipe sloping down from the pump with a single drain downstream of the break. Summary results include the following:

- Maximum encasement pressure from a primary pipe break is $253 \mathrm{psig}$ with a piping section of 7000 feet equivalent length, and 240 psig for a piping section of 4000 feet equivalent length

- Pressure range for the encasement from primary pipe break is $24 \mathrm{psig}-253 \mathrm{psig}$ 


\section{RPP-6759 REV 0}

- Temperature effects are negligible

- Pressure increases are minimal over the range of probable waste bulk densities

- Increasing pipe section length has no effect on pressure for upward sloping pipe with a low-point drain

The following information is reproduced from the Appendix A, Table 1.

Table 1. Maximum Encasement Pressure (psig) From Primary Pipe Break.

\begin{tabular}{|c|c|c|c|c|c|}
\hline \multirow{2}{*}{ Case } & \multirow{2}{*}{$\begin{array}{l}\text { Plpe Slope } \\
\text { In Flow } \\
\text { Direction }\end{array}$} & \multicolumn{4}{|c|}{$\begin{array}{c}\text { Equivalent Length (feet) of Encasement Section } \\
\text { Piping Between Pits }\end{array}$} \\
\hline & & 1,000 & 2,000 & 4,000 & 7000 \\
\hline \multicolumn{6}{|l|}{ 1-inch Drain } \\
\hline Two Drain & Up & 130 & 134 & 140 & 147 \\
\hline Low Point Drain & Up & 223 & 223 & 223 & 223 \\
\hline Low Point Drain & Down & 221 & 229 & 240 & 253 \\
\hline \multicolumn{6}{|l|}{ 2-inch Drain } \\
\hline Two Drain & Up & 24 & 31 & 40 & 48 \\
\hline Low Point Drain & Up & 78 & 88 & 89 & 89 \\
\hline Low Point Drain & Down & 94 & 127 & 168 & 204 \\
\hline
\end{tabular}

Note that the pressure within the encasement piping section, between pits for a postulated primary pipe break, decreases as the distance from the pump increases. 


\subsection{SYSTEM BACKGROUND}

The transfer piping system used for liquid waste transfer within Hanford Tank Farm Contractor facilities is generally comprised of a pipe within a pipe, termed double-encased piping. An interior pipe is used for the actual material transport and is termed primary piping. The outer piping is called secondary piping, and is used to contain any leakage from the primary piping and direct it to a leak detection and alarm system. The secondary piping may also provide the structures needed to support the primary piping, and standpipes for leak detection installation/maintenance and integrity testing. A view of a typical double-encased piping and leak detection system is shown below in Figure 1, copied from the Double-Shell Tank Transfer Piping Subsystem Specification (CHG 2000).

Figure 1. Double Encased Piping and Leak Detection

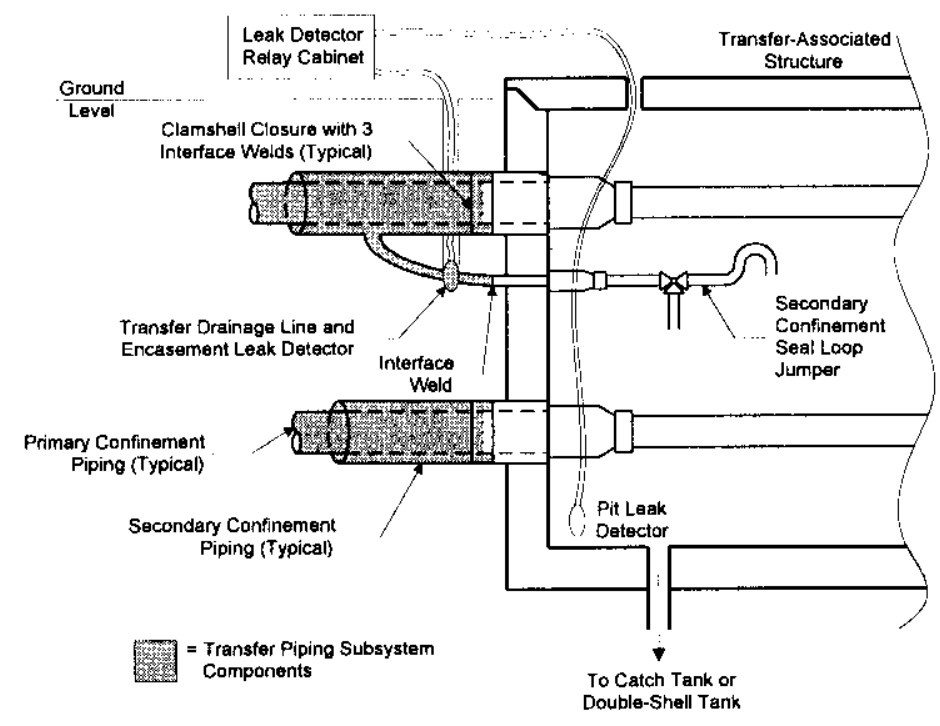

Double-encased piping was used in the Hanford tank piping distribution system for all new systems installed in the last 30 years except where the piping transits through concrete pits. In the case of pit transit, the concrete pits and covers provide secondary confinement and contain leak detection, eliminating the need for secondary encasement piping. Further details of transfer piping design specifications may be found in the Double-Shell Tank Transfer Piping Subsystem Specification (CHG 2000). 


\subsection{CALCULATION DETAILS}

Detailed calculations are contained in Appendix A, Calculation Number RPP-LJJ-004. This section lists basic information regarding those calculations.

A representative double-encased pipe routing was modeled in the analysis using design characteristics from the project W-314 transfer lines. The W-314 design was used to estimate pipe guide spacing, pipe anchor spacing, and drain line size and configuration.

\subsection{ASSUMPTIONS}

- Primary Pipe: 3 -in. schedule 40 , stainless steel

- Secondary Pipe: 6-in. schedule 40, carbon steel

- Drain Pipe in encasement: 1-in. and 2-in. schedule 40, carbon steel

- Primary pipe failure: guillotine break

- Maximum waste density is $1.5 \mathrm{~kg} / \mathrm{L}$

- Pump deadhead pressure is $650 \mathrm{psig}$ at maximum waste density, with pump run-out at $285 \mathrm{gpm}$

- Encasement drains do not plug (based upon very high velocities through these lines)

\subsection{MODELING OF THE PIPE BREAK}

\subsubsection{Pipeline Failure}

The assumption of how the pipeline fails maximizes flow and secondary encasement pressure. Normal pipeline failure on straight piping sections, apart from external dropping or crushing scenarios, involves holes or slits in the metal wall from corrosion or weld failure. A large pressure drop occurs across this hole or slit opening minimizing the pressure buildup in any encasement. The primary pipe might shift because of the hydraulic forces at the break but a majority of the flow would still remain in the primary piping. The calculation in this report assumes a guillotine break that allows a transfer of the primary pipe contents into the primary and encasement pipeline. This is depicted below in Figure 2. 
Figure 2. Liquid Flow After Guillotine Break

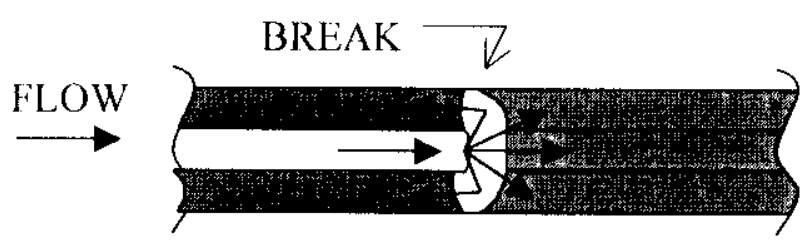

(Shading shows resultant

flow

The percentage of flow distributed between the encasement and the downstream primary pipe is calculated based upon downstream pressure losses in both the primary and secondary pipe, and the pump response.

\subsubsection{Immediate Encasement Fill-up}

No effect for encasement fill-up was included in the calculation. For example, a 4000 foot encasement pipe section length would take approximately 20 minutes to fill before experiencing maximum pressure. During this time the transfer pump would most probably experience "runout" - a condition where low-volume flow through the pump would cause cavitation and pressure fluctuations.

\subsection{HYDRAULIC ANALYSIS}

Standard hydraulic (pressure and flow) formulas were used, and solved with MathCad-2000ß). Piping properties, and basic flow parameters/coefficients were taken from standard industrial and technical sources. Because of the non-standard geometry of the encasement tlow obstructions (pipe guides, supports, and anchors) the pressure loss (k-resistance factors) from these flow obstructions was based upon the equivalent flow-area concept. This is a highly approximate method, and requires flow testing to obtain more accurate results. A low estimate of the kresistance factors will result in an under prediction of the maximum pressure in the encasement piping.

Non-linear equations were then developed taking into account effects from drain discharge, supports within the encasement area, and pipe configuration. The calculations use an iterative process to balance flows, friction effects, and pressure losses to obtain steady-state pressure conditions. 


\section{RPP-6759 REV 0}

\subsection{CONCLUSIONS}

The maximum expected internal pressure experienced by 6-in. encasement piping is well below the design pressure criteria values normally defined. At a minimum, pneumatic testing pressure limits may be reduced allowing safer inspection during construction. Design Authorities may employ the reduced pressure values to fabrication requirements.

It is recommended that future double-encased piping systems, of 4000 equivalent feet or less, employ one of two options for encasement pressure design criteria:

1. Design encasement to 240 psig for a system with a low point 1 -inch diameter drain pipe, or 170 psig for a system with a low point 2-inch diameter drain pipe, or

2. Perform a specific case analysis with the same pipe pressure calculation methodology.

The recommended pressure values in \#1 above assume a design pump shut-off head of 650 psig. These values may be linearly reduced with lower pump shut-off heads.

A significant reduction in the encasement design pressure can be obtained if both a high and low point drain are provided. Under this condition, and for an equivalent pipe section of 4000 feet, the minimum design encasement pressure could be limited to $140 \mathrm{psig}$ with 1 -inch diameter drains and 40 psig with 2-inch diameter drains.

\subsection{ABBREVIATIONS}

gpm gallons per minute

in. inch

$\mathrm{kg} / \mathrm{L} \quad$ kilogram per liter

psig pounds per square inch, gauge

\subsection{REFERENCES}

CHG, 2000, Double-Shell Tank Transfer Piping Subsystem Specification, HNF-4161, Rev. 0, Numatec Hanford Corporation for CH2M HILL Hanford Group, Inc., Richland, Washington.

McGrew, D. L., 1999a, Requirements Analysis Study - Transfer Piping Project Development Specification, HNF-SD-W314-TI-009, Rev. 2, Numatec Hanford Corporation for CH2M HILL Hanford Group, Inc., Richland, Washington.

McGrew, D. L., 1999b, Project Design Concept for Transfer Piping for Project W-314, Tank Farm Restoration and Safe Operation, HNF-SD-W314-TI-009, Rev. 2, Numatec Hanford Corporation for CH2M HILL Hanford Group, Inc., Richland, Washington. 
RPP-6759 REV 0

APPENDIX A.

DETAILED CALCULATION OF SECONDARY PIPING ENCASEMENT PRESSURE FROM PRIMARY PIPE FAILURE 


\section{RPP-6759 REV 0}

This page intentionally left blank.

A-ii 


\section{EVALUATION ANALYSIS}

Client: $\quad$ CH2M Hill Hanford Group, Inc.

Subject: Secondary Encasement Pipe Pressure Due to Primary Pipe Break in Waste Tank Transfer Piping System

Location: 200 Area - Hanford Site, Richland, Washington
WO/Job No.

Date: $09 / 0 \overline{7 / 2000}$ Checked: $09 / 08 / 2000$ Revised:
Calc. No. RPP-LJJ-004

Revision: $\underline{0}$ Page No. -1 of 34

\section{PRESSURE IN SECONDARY ENCASEMENT PIPE DUE TO BREAK IN PRIMARY TRANSFER PIPE}

\section{PROBLEM}

Determine maximum pressure in secondary encasement pipe sections for postulated break in primary pipe during waste transfer operations within 200-East Area between double-shell tanks and proposed waste vitrification plant. Consider cases with only one drain at low point within the encasement section under consideration and with two drains (see Figure 1).

\section{APPROACH}

Basic pipeline hydraulic principles are applied to determine the maximum steady-state pressure in the secondary encasement pipe sections for a postulated break in the primary pipe during waste transfer operations. The resulting nonlinear system of equations that model the hydraulic conditions are solved using Mathcad 2000 Professional (Mathcad is a registered trademark of MathSoft, Inc. of Cambridge, Massachusetts). Head losses due to friction, exit losses at drains and at the pipe break are calculated. In addition, losses due to sudden contractions or enlargements from the primary pipe supports in the annulus region and changes in flow area from the annulus to drain pipe(s) are estimated using an equivalent hydraulic diameter approach to determine the K-resistance loss factors (see Blevins 1984). The conservation of mass (continuity) and energy (Bernoulli theorem) are applied between nodes (as numbered in Figure 1) and at the pipe break location plus a characteristic pump head relation is modeled to form the nonlinear system of equations that govern the steady-state flow resulting from a primary pipe break.

Figure 1. Transfer Pipe Layout Schematic.

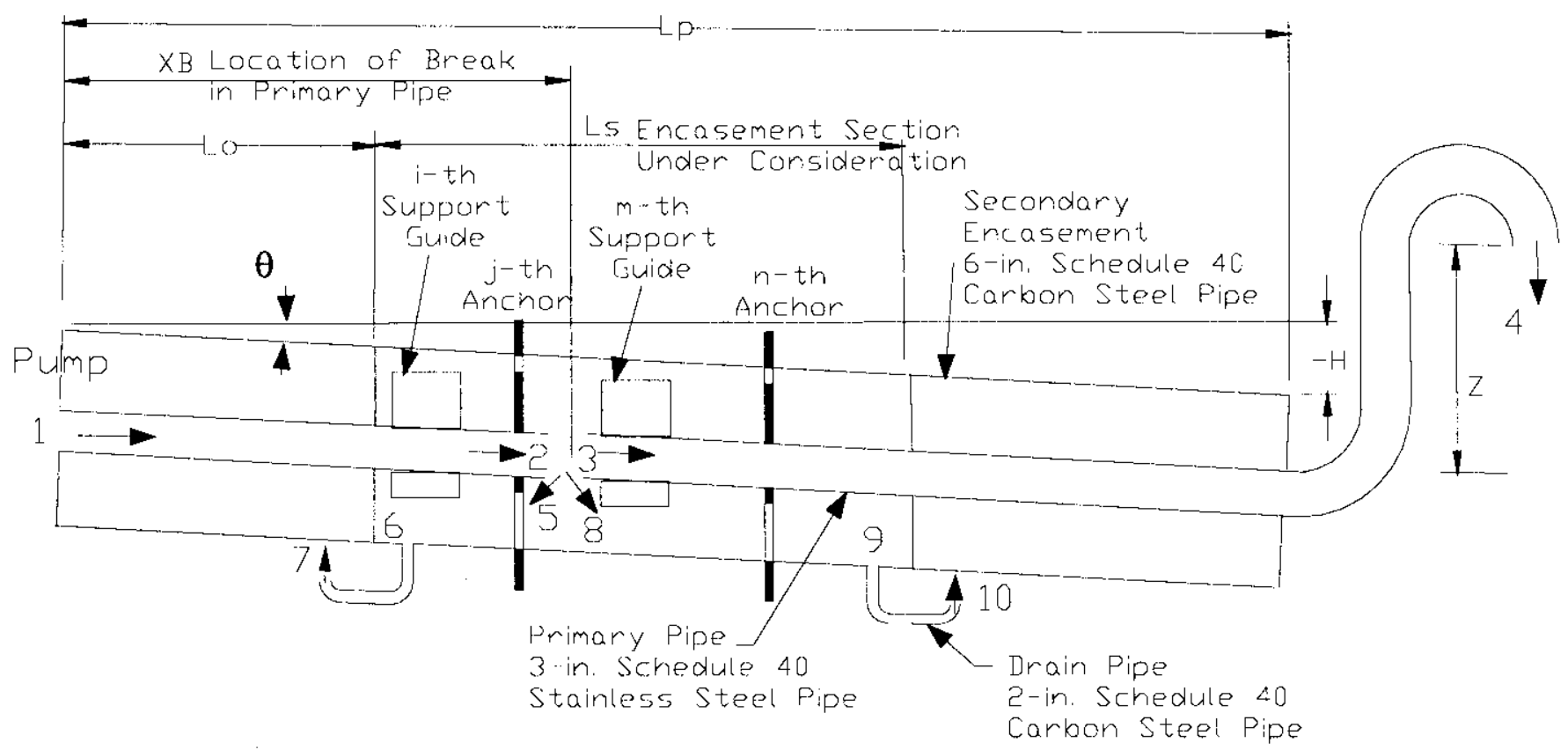


CH2MHILL Hanford Group, Inc.

\section{EVALUATION ANALYSIS}

Client: $\quad$ CH2M Hill Hanford Group, Inc.

Subject: Secondary Encasement Pipe Pressure Due to Primary Pipe Break in Waste Tank Transfer Piping System

Location: 200 Area - Hanford Site, Richland, Washington
RPP-6759 REV 0

Calc. No. RPP-LJJ-004

Revision: $\underline{0}$

Page No. 2 of 34

WO/Job No.

Date: $09 / \overline{07 / 2000}$ By: L. J. Julyk $\mathscr{C}$.

Checked: $09 / 08 / 2000$ By: T.C. Oten 200

Revised:

By:

The pressure in the primary pipe and encasement pipe with a break in the primary pipe are calculated through an iterative process. Initially the system flow rate is a constant as determined by the pump characteristics and system line losses. When the break occurs, the pump flow rate will increase depending on the location and size of the break. The increase in flow rate will cause both a pump head decrease and an increase in frictional line losses until a new equilibrium condition is reached.

\section{ASSUMPTIONS}

To bound the maximum pressure in the secondary encasement pipe sections the following conservative assumptions are applied:

1 Assume maximum waste bulk density during waste transfer of $1.5 \mathrm{~kg} / \mathrm{L}$ (conservative, see Figure $6 \mathrm{c}$ ).

2 Assume pump dead head pressure of 650 psig at maximum waste density and pump run-out flow rate of $285 \mathrm{gpm}$ (see Figure 2).

3 Assume pipe roughness values of 50 mils due to general corrosion in carbon steel secondary encasement pipe and in drain pipe(s) and a pipe roughness value of 2 mils in the stainless steel primary pipe (conservative combination).

4 Assume a waste transfer temperature of $10^{\circ} \mathrm{C}$ (conservative, see Figure 6b).

5 Assume a minimum pipe slope of $0.25 \%$ (typical specification limit for Hanford Site underground transfer piping).

6 Assume that pressure losses due to support guides and anchors can be approximated (first order approximation) from corresponding pressure losses due to long hole orifice plates with equivalent flow area.

\section{SUMMARY RESULTS}

Three cases for both a 1- and 2-in. drain line are considered. The resulting estimated maximum steady-state pressure in the secondary encasement pipe sections due to a postulated break in the primary pipe is summarized in Table 1. The predicted maximum steady-state pressure in the secondary encasement pipe as a function of primary pipe break location relative to the pump for various lengths of secondary encasement pipe sections between pits for each of the three cases are shown in Figures $6 a, 7$, and 8 for a 1 -in. drain line and Figures 9, 10, and 11 for a 2 -in. drain line. The encasement section under consideration is conservatively assumed to start at the pump $\left(L_{0}=0 \mathrm{ft}\right)$. If the encasement section between pits is located some distance from the pump ( $L_{0}>0 \mathrm{ft}$ ) then the maximum encasement pressure resulting from a primary pipe break within this section will decrease as $L_{0}$ increases.

The effect of waste temperature on the encasement pressure due to a primary pipe break is shown in Figure $6 \mathrm{~b}$. The encasement pressure decreases with increasing waste temperature but the effect is negligible. A lower bound waste temperature of $10 \circ \mathrm{C}$ is conservatively assumed throughout this analysis. The effect of waste bulk density is shown in Figure $6 c$. The encasement pressure increases with increasing waste bulk density. The effect of waste density is more significant than the effect of waste temperature. An upper bound waste bulk density of $1.5 \mathrm{~kg} / \mathrm{L}$ is conservatively assumed throughout this analysis.

The worse case is obtained by conservatively assuming that the secondary encasement pipe section between pits is equal in length to the total primary pipe length. This is a very conservative assumption because there are typically a number of secondary encasement pipe sections in the total length of the transfer piping system. The maximum pressure depends on the location of the secondary encasement pipe section under consideration relative to the pump and the location of the break within that section as well as the length of the secondary encasement section. 
CH2MHILL Hanford Group, Inc.

RPP-6759 REV 0

\section{EVALUATION ANALYSIS}

Client: $\quad \mathrm{CH} 2 \mathrm{M}$ Hill Hanford Group, Inc.

Subject: Secondary Encasement Pipe Pressure Due to Primary Pipe Break in Waste Tank Transfer Piping System

Location: 200 Area-Hanford Site, Richland, Washington
WO/Job No.

Date: $09 / \overline{07 / 2000}$ Checked: $09 / 08 / 2000$ Revised:
Calc. No. RPP-LJJ-004

Revision: 0

Page No. -3 of 34
Bंy: L. J. Julyk fg.

By: T. C. Oterrsco

By:

The predicted maximum pressure in a secondary encasement pipe section decreases as the length of the section decreases and as the location of the encasement section increases relative to the pump. Note however that in the case of an upward sloping pipe with a low point drain (see Figures 7 and 10) the predicted pressures in the encasement pipe as a function of break location fall on a common curve for each encasement section length. An increase in the number of pipe supports and/or pipe anchors within the secondary encasement pipe section under consideration also increases the predicted maximum pressure. The spacing of support guides $(9 \mathrm{ft})$ and anchors $(110 \mathrm{ft})$ selected are average values based on pipe layout given in $\mathrm{H}-14-102663$.

The area of greatest uncertainty in these results is in the prediction of the pressure drop associated with the support guides and anchors because of their unique geometry. A more accurate characterization of the pressure drop for these flow restrictions is best obtained through testing.

Table 1. Maximum Encasement Pressure (psig) Due to Waste Transfer Primary Pipe Break.

\begin{tabular}{|c|c|c|c|c|c|c|c|}
\hline \multirow{2}{*}{ Case } & \multirow{2}{*}{\begin{tabular}{|c} 
Pipe \\
Slope in \\
Flow \\
Direction
\end{tabular}} & \multirow{2}{*}{$\begin{array}{l}\text { Primary } \\
\text { Pipe } \\
\text { Length } \\
\text { (ft) }\end{array}$} & \multicolumn{4}{|c|}{ Length ( $\mathrm{ft}$ ) of Encasement Section Between Pits } & \multirow{2}{*}{ Figure } \\
\hline & & & 1,000 & 2,000 & 4,000 & 7,000 & \\
\hline \multicolumn{8}{|l|}{ 1-in. Drain } \\
\hline Two Drain & Up & 7,000 & 130 & 134 & 140 & 147 & $6 a$ \\
\hline Low Point Drain & Up & 7,000 & 223 & 223 & 223 & 223 & 7 \\
\hline Low Point Drain & Down & 7,000 & 221 & 229 & 240 & 253 & 8 \\
\hline \multicolumn{8}{|l|}{ 2-in. Drain } \\
\hline Two Drain & $\mathrm{Up}$ & 7,000 & 24 & 31 & 40 & 48 & 9 \\
\hline Low Point Drain & Up & 7,000 & 78 & 88 & 89 & 89 & 10 \\
\hline Low Point Drain & Down & 7,000 & 94 & 127 & 168 & 204 & 11 \\
\hline
\end{tabular}

$L_{o}=0 \mathrm{ft}$, pipeline slope $=0.25 \%$, waste temperature $=10^{\circ} \mathrm{C}$, and waste bulk density $=1.5 \mathrm{~kg} / \mathrm{L}$ (see Figure 2 for assumed pump curve). 
CH2MHILL Hanford Group, Inc.

\section{EVALUATION ANALYSIS}

Client: $\quad$ CH2M Hill Hanford Group, Inc.

Subject: Secondary Encasement Pipe Pressure Due to Primary Pipe Break in Waste Tank Transfer Piping System

Location: 200 Area - Hanford Site, Richland, Washington
RPP-6759 REV 0

Calc. No. RPP-LJJ-004

Revision: 0

Page No. -4 of 34

WO/Job No.

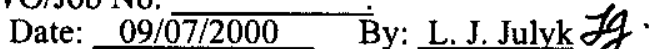

Checked: $09 / 08 / 2000$ By: T. C. Oten co

Revised:

By:

\section{REFERENCES}

Blevins, R. D., 1984, Applied Fluid Dynamics Handbook, Van Nostrand Reinhold Company Inc., New York, New York.

CRANE, 1988, Flow of Fluids through Valves, Fittings, and Pipe, Technical Paper No. 410, Crane Co., Chicago Illinois.

Estey, S. D. and T. A. Hu, 1998, Flow Velocity Analysis for Avoidance of Solids Deposition During Transport of Hanford Tank Waste Slurries, HNF-2728, Rev. 0, Lockheed Martin Hanford Corporation, Richland, Washington.

Estey, S. D, 2000, "Alternatives Generation and Analysis for Waste Feed Delivery Transfer Pump Discharge Pressure: Hanford Tank Waste Physical Property Estimates," Internal Memorandum, 74B50-00-001-R2, to W. L. Wills, CH2M Hill, Hanford Group, Inc., dated April 10, 2000.

Lyons J. L., 1982, Lyons' Valve Designer's Handbook, Van Nostrand Reinhold Company, New York, New York.

Mathcad 2000 Professional, MathSoft, Inc., Cambridge, Massachusetts.

Olujuc, Z., 1981, Compute Friction Factors Fast for Flow in Pipes, Chemical Engineering, December Issue.

RPP-5667, 2000, Stochastic Consequence Analysis for Waste Leaks, Revision 0, B. E. Hay, et al., Fluor Federal Services, Richland, Washington.

Shook, C. A., and M. C. Roco, 1991, Slurry Flow Principles and Practice, Butterworth-Heinemann, Boston, MA.

H-14-102662, Piping Details, Revision 2, dated May 11, 2000.

H-14-102663, Piping Support Plan 3" SN-633-M9, Revision 0.

H-14-102695, Piping Piping Pump Pits 241-AZ-01A\&02A Modification Details, Revision 1. 
EVALUATION ANALYSIS

Client: $\quad$ CH2M Hill Hanford Group, Inc.

Subject: Secondary Encasement Pipe Pressure Due to Primary Pipe Break in Waste Tank Transfer Piping System

Location: 200 Area - Hanford Site, Richland, Washington
WO/Job No.

Date: $09 / 07 / 2000$ Checked: $09 / 08 / 2000$ Revised:
Calc. No. RPP-LJJ-004

Revision: 0

Page No. 5 of 34

ANALYSIS

$\mathrm{gpm}:=\frac{\mathrm{gal}}{\min } \quad \mathrm{mil}:=\frac{\text { in }}{1000} \quad \mathrm{cP}:=\frac{\text { poise }}{100} \quad \mathrm{psi}:=1 \cdot \frac{\mathrm{lbf}}{\mathrm{in}^{2}} \quad$ units $\mathrm{TOL}=1 \times 10^{-3}$ $\mathrm{CTOL}=1 \times 10^{-3}$

\section{Waste Properties}

$\rho:=1.5 \cdot \frac{\mathrm{kg}}{\text { liter }} \quad$ bulk density (input data)

The density and viscosity of water as a function of temperature $\left({ }^{\circ} \mathrm{C}\right)$ were obtained from Shook and Roco (1991) and Estey and $\mathrm{Hu}(1998)$ as

$$
\rho_{\text {water }}\left(t_{C}\right):=\left[999.7-0.10512 \cdot\left(t_{C}-10\right)-0.005121 \cdot\left(t_{C}-10\right)^{2}+0.00001329 \cdot\left(t_{C}-10\right)^{3}\right] \cdot \frac{k g}{\mathrm{~m}^{3}} \quad \begin{aligned}
& \text { mass density of } \\
& \text { water }
\end{aligned}
$$

viscosity of water as a function of temperature $\left({ }^{\circ} \mathrm{C}\right)$

$$
\mu_{\text {water }}\left(\mathrm{t}_{\mathrm{C}}\right):=\mid \begin{aligned}
& 100 \cdot \exp \left[\ln (10) \cdot\left[\frac{1301}{998.333+8.1855 \cdot\left(\mathrm{t}_{\mathrm{C}}-20\right)+0.00585 \cdot\left(\mathrm{t}_{\mathrm{C}}-20\right)^{2}}-3.30233\right]\right] \cdot \mathrm{cP} \text { if } \mathrm{t}_{\mathrm{C}} \leq 20 \\
& (1.002) \cdot \exp \left[\ln (10) \cdot\left[\frac{\left[1.3272 \cdot\left(20-\mathrm{t}_{\mathrm{C}}\right)-0.001053 \cdot\left(\mathrm{t}_{\mathrm{C}}-20\right)^{2}\right]}{\mathrm{t}_{\mathrm{C}}+105}\right]\right] \cdot \mathrm{cP} \text { otherwise }
\end{aligned}
$$

The above properties of water can be assumed for the pipeline flush condition as a function of the temperature of the flush water. These properties can vary if the flush water is treated.

The viscosity of the carrier liquid is given in Estey 2000 by the following relation:

$\rho \quad$ density of carrier liquid with dissolved solids

$\mathrm{x}_{\text {salt }}:=0.9 \quad$ fraction of dissolved solids composed of sodium and other salts

$\mathrm{x}_{\text {caustic }}:=0.1 \quad$ fraction of dissolved solids composed of sodium hydroxide

$$
\mu\left(\rho, t_{C}\right):=\mu_{\text {water }}\left(t_{C}\right) \cdot\left[x_{\text {salt }} \cdot\left[1+1.071 \cdot\left(\frac{\rho}{\rho_{\text {water }}\left(t_{C}\right)}-1\right)\right]+x_{\text {caustic }} \cdot \exp \left[\left[7.143 \cdot\left(\frac{\rho}{\rho_{\text {water }}\left(t_{C}\right)}-1\right)\right]^{1.15}\right]\right]
$$

The following temperature conversion functions are defined to convert between Fahrenheit and Celsius temperature scales.

$$
\begin{aligned}
& \mathrm{T}_{\mathrm{F}}\left(\mathrm{t}_{\mathrm{C}}\right):=\frac{9}{5} \cdot \mathrm{t}_{\mathrm{C}}+32 \quad \mathrm{~T}_{\mathrm{C}}\left(\mathrm{t}_{\mathrm{F}}\right):=\frac{5}{9} \cdot\left(\mathrm{t}_{\mathrm{F}}-32\right) \quad \mathrm{t}_{\mathrm{C}}:=10 \quad \mu\left(\rho, \mathrm{t}_{\mathrm{C}}\right)=11.708 \mathrm{cP} \\
& t_{C}:=60 \quad \mu\left(\rho, t_{C}\right)=5.193 \mathrm{cP}
\end{aligned}
$$


CH2MHILL Hanford Group, Inc.

\section{EVALUATION ANALYSIS}

Client: $\quad$ CH2M Hill Hanford Group, Inc.

Subject: Secondary Encasement Pipe Pressure Due to Primary Pipe Break in Waste Tank Transfer Piping System

Location: 200 Area - Hanford Site, Richland, Washington
Calc. No. RPP-LJJ-004

Revision: 0

Page No. -6 of 34

WO/Job No.

Date: $09 / \overline{07 / 2000}$ By: L. J. Julyk 78 .

Checked: $09 / 08 / 2000$ By: T. C. Oterree

Revised:

\section{Pump Characteristics}

Idealistic pump curve intended to bound the pressure and flow characteristics of all waste transfer pumps for farm-to-farm transfers as well as waste feed delivery to vitrification facility (RPP-5667)

$H_{p s}:=1440 \cdot f t \quad$ pump shut off head

$\mathrm{Q}_{\mathrm{p}_{-} \text {runout }}:=285 \cdot \mathrm{gpm}$ run-out flow rate

$\mathrm{H}_{1}:=-0.29729 \cdot \mathrm{ft} \quad \mathrm{H}_{2}:=-0.01465 \cdot \mathrm{ft} \quad \mathrm{H}_{3}:=-5.61 \cdot 10^{-6} \cdot \mathrm{ft}$

$$
\mathrm{H}_{\mathrm{dh}}\left(\mathrm{p}_{\mathrm{dh}}\right):=\frac{\mathrm{p}_{\mathrm{dh}}}{1.5 \cdot \frac{\mathrm{kg}}{\text { liter }} \cdot \mathrm{g}}
$$

adjusted dead head (input data)

$\mathrm{p}_{\mathrm{dh}}:=650 \cdot \mathrm{psi}$ at $1.5 \mathrm{~kg} / \mathrm{L}$
$\mathrm{H}_{\mathrm{dh}}\left(\mathrm{p}_{\mathrm{dh}}\right)=1000 \mathrm{ft}$

$H_{p}\left(Q_{p}, p_{d h}\right):=\left[H_{p s}+H_{1} \cdot \frac{Q_{p}}{g p m}+H_{2} \cdot\left(\frac{Q_{p}}{g p m}\right)^{2}+H_{3} \cdot\left(\frac{Q_{p}}{g p m}\right)^{3}\right] \cdot \frac{H_{d h}\left(p_{d h}\right)}{H_{p s}}$

$\mathrm{p}_{\mathrm{p}}\left(\mathrm{Q}_{\mathrm{p}}, \rho, \mathrm{p}_{\mathrm{dh}}\right):=\mathrm{H}_{\mathrm{p}}\left(\mathrm{Q}_{\mathrm{p}}, \mathrm{p}_{\mathrm{dh}}\right) \cdot \rho \cdot \mathrm{g}$

pump head characteristic curve

pump discharge pressure

Figure 2a. Idealized Pump Head Curve.

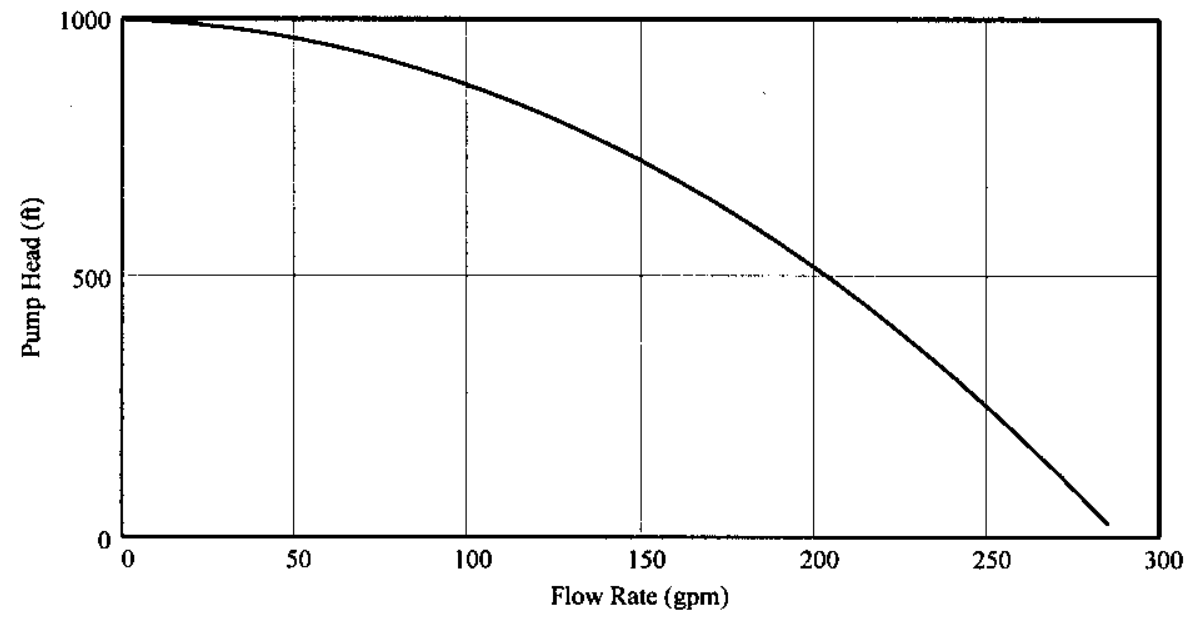

Figure 2b. Idealized Pump Discharge Pressure Curve.

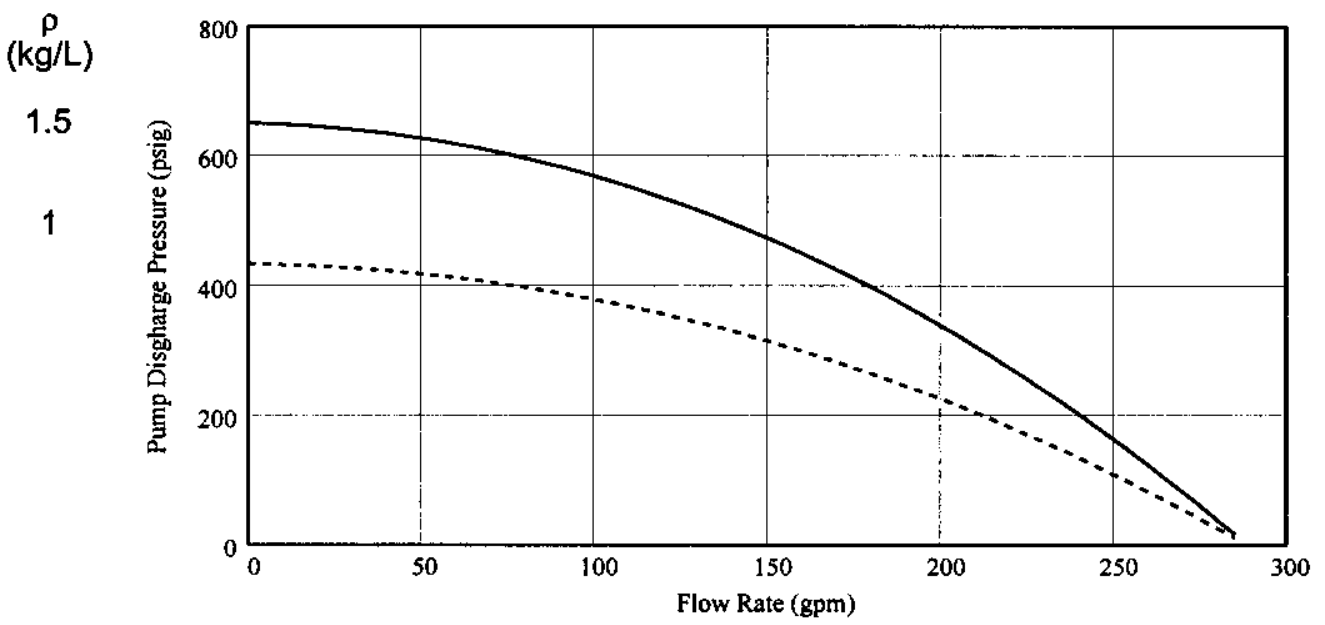


CH2MHILL Hanford Group, Inc.

RPP-6759 REV 0

\section{EVALUATION ANALYSIS}

Client: $\quad$ CH2M Hill Hanford Group, Inc.

Subject: Secondary Encasement Pipe Pressure Due to Primary Pipe Break in Waste Tank Transfer Piping System

Location: 200 Area - Hanford Site, Richland, Washington
WO/Job No.

Date: $09 / \overline{07 / 2000}$ Checked: $09 / 08 / 2000$ Revised:
Calc. No. RPP-LJJ-004

Revision: 0

Page No. 7 of 34

\section{Darcy Friction Factor}

$\mathrm{R}_{\mathrm{e}}(\mathrm{D}, \mathrm{v}, \rho, \mu):=\frac{\rho}{\mu} \cdot \mathrm{D} \cdot \mathrm{v} \quad$ Reynolds number

$\eta=\frac{\varepsilon}{D} \quad$ relative roughness ratio

Olujic (1981) reports the following Darcy friction factor approximation developed by Churchill in 1977 that includes the laminar and turbulent regimes as well as the transition regime between laminar and turbulent flow

$$
f\left(R_{e}, \eta\right):=\left\{\begin{array}{l}
A \leftarrow\left[2.457 \cdot \ln \left[\frac{1}{\left(\frac{7}{R_{e}}\right)^{0.9}+0.27 \cdot \eta}\right]\right]^{16} \\
B \leftarrow\left(\frac{37530}{R_{e}}\right)^{16} \\
8 \cdot\left[\left(\frac{8}{R_{e}}\right)^{12}+\left(\frac{1}{A+B}\right)^{\frac{3}{2}}\right]^{12}
\end{array}\right.
$$

primary pipe is stainless steel and secondary encasement is carbon steel

$$
\begin{aligned}
& \varepsilon=\text { pipe roughness, seamless steel pipe (Blevins 1984) } \\
& \text { new condition } \varepsilon=0.8 \text { to } 4 \text { mils (carbon or stainless steel) } \\
& \text { light rust } \varepsilon=6 \text { to } 40 \text { mils (carbon, } 1 / 3 \text { value for stainless) } \\
& \text { general rust } \varepsilon=40 \text { to } 100 \text { mils (carbon steel only) }
\end{aligned}
$$




\section{CH2MHILL Hanford Group, Inc.}

EVALUATION ANALYSIS

Client: $\quad$ CH2M Hill Hanford Group, Inc

Subject: Secondary Encasement Pipe Pressure Due to Primary Pipe Break in Waste Tank Transfer Piping System

Location: 200 Area - Hanford Site, Richland, Washington
WO/Job No.

Date: $09 / \overline{7 / 2000}$

Checked: $09 / 08 / 2000$

Revised:
Calc. No. RPP-LJJ-004

Revision: 0

Page No. -8 of 34

\section{Pipe Parameters}

$\mathrm{A}_{\mathrm{f}}\left(\mathrm{D}_{\mathrm{i}}\right):=\frac{\pi}{4} \cdot \mathrm{D}_{\mathrm{i}}^{2}$

flow area of pipe

Primary transfer pipe, 3-in. schedule 40

$\mathrm{D}_{\mathrm{Pi}_{\mathrm{i}}}:=3.068 \cdot$ in internal diameter)

$\mathrm{D}_{\mathrm{Po}}:=3.5 \cdot$ in outside diameter

$A_{P}:=A_{f}\left(D_{P i}\right)$ $\mathrm{A}_{\mathrm{P}}=7.393 \mathrm{in}^{2}$

flow area of pipe

\section{Drain pipe}

1 -in. schedule 40

$\mathrm{D}_{\mathrm{Dli}}:=1.049 \cdot$ in

$A_{D 1}:=A_{f}\left(D_{D 11}\right)$

$\mathrm{A}_{\mathrm{D} 1}=0.864 \mathrm{in}^{2}$ 2-in. schedule 40

$\mathrm{D}_{\mathrm{D} 2 \mathrm{i}}:=2.067 \cdot$ in

$A_{D 2}:=A_{f}\left(D_{D 2 i}\right)$

$A_{\mathrm{D} 2}=3.356 \mathrm{in}^{2}$ nominal internal diameter

flow area of pipe

Secondary encasement pipe annulus, 6-in. schedule 40

$\mathrm{D}_{\mathrm{Si}}:=6.065 \cdot$ in

$\mathrm{A}_{\mathrm{S}}:=\frac{\pi}{4} \cdot\left(\mathrm{D}_{\mathrm{Si}}{ }^{2}-\mathrm{D}_{\mathrm{Po}^{2}}{ }^{2}\right) \quad \mathrm{A}_{\mathrm{S}}=19.269 \mathrm{in}^{2}$

$\mathrm{P}_{\mathrm{S}}:=\pi \cdot\left(\mathrm{D}_{\mathrm{Si}}+\mathrm{D}_{\mathrm{Po}_{\mathrm{O}}}\right)$

$P_{S}=30.049$ in

$\mathrm{D}_{\mathrm{H} \_ \text {annulus }}:=4 \cdot \frac{\mathrm{A}_{\mathrm{S}}}{\mathrm{P}_{\mathrm{S}}}$ internal diameter flow area of annulus region between primary and secondary pipe wetted perimeter

hydraulic diameter for secondary encasement pipe annulus

\section{K-resistance Loss Factors}

Head losses in the annulus region between the primary pipe and the secondary encasement due to steady-state flow in the annulus region resulting from a primary pipe break must be considered. Pipe bends are included in the effective length of the pipe section or pipe drain effective length. The head loss due to sudden contractions or enlargements from the primary pipe supports and changes in flow area from the annulus to drain pipe are estimated using an equivalent hydraulic diameter approach to determine the K-resistance loss factors (see Blevins 1984). That is, the head loss is given by $h_{L}=K V 2 / 2 \mathrm{~g}$ where $K$ (K-resistance loss factors) is estimated using an equivalent hydraulic diameter approach (see below) and $V$ is the flow velocity in the annulus region of the pipe (upstream of the obstruction).

The primary transfer pipe is supported within the secondary encasement pipe at various locations along the pipeline by either pipe supports (Figure 3), pipe guides (Figure 4), or pipe anchors (Figure 5). The pipe supports typically occur at pipe bend locations. The pipe guides are typically spaced at 8 or 10 foot increments. The spacing of the pipe anchors is more variable, in the range from 10 to 20 times the spacing of the pipe guides (see H-14-102663). For simplicity, the head loss from a pipe support will be included for every 4th pipe guide to account for the pipe supports at pipe bends. 


\section{EVALUATION ANALYSIS}

Client: $\quad$ CH2M Hill Hanford Group, Inc.

Subject: Secondary Encasement Pipe Pressure Due to Primary Pipe Break in Waste Tank Transfer Piping System

Location: 200 Area - Hanford Site, Richland, Washington
WO/Job No.

Date: $09 / \overline{7 / 2000}$ Checked: $09 / 08 / 2000$ Revised:
Calc. No. RPP-LJJ-004

Revision: 0

Page No. 9 of 34

By:

Figure 3. Encased Pipe Support. (H-14-102662)

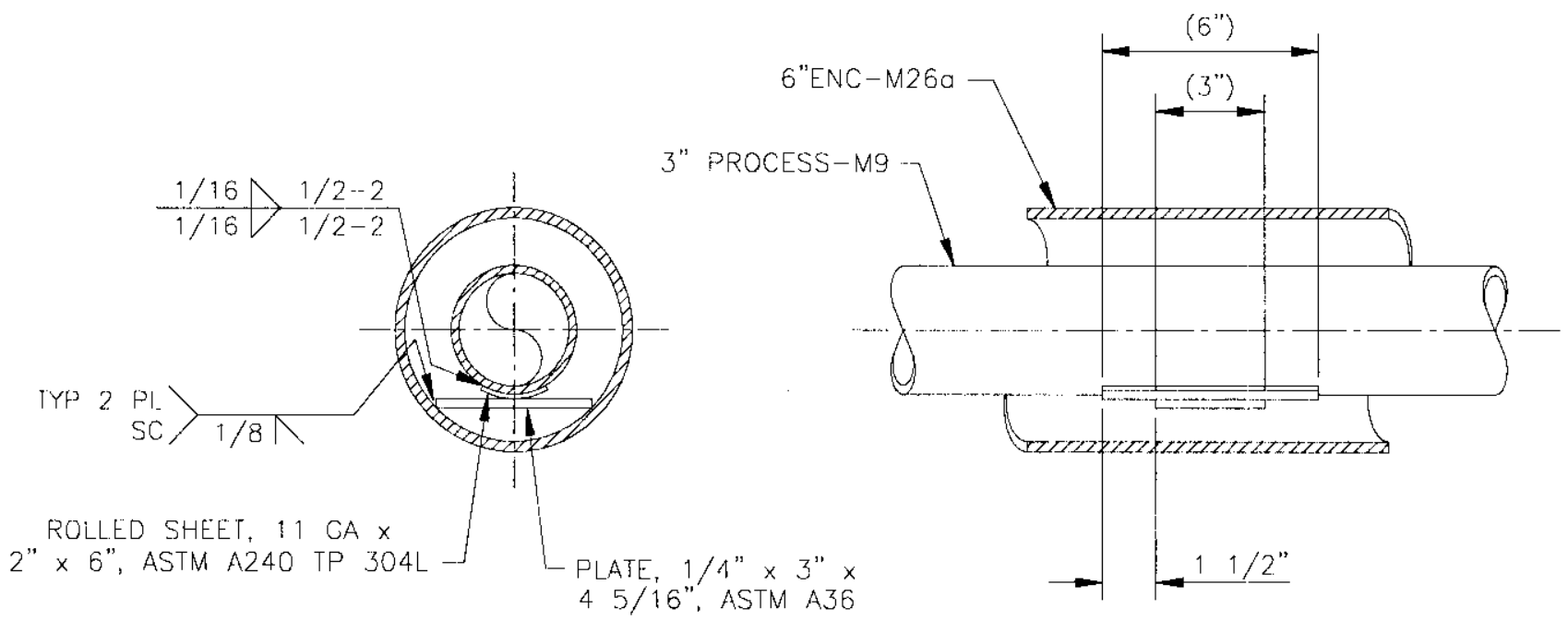




\section{CH2MHILL Hanford Group, Inc.}

RPP-6759 REV 0

\section{EVALUATION ANALYSIS}

Client: $\quad$ CH2M Hill Hanford Group, Inc.

Subject: Secondary Encasement Pipe Pressure Due to Primary Pipe Break in Waste Tank Transfer Piping System

Location: 200 Area - Hanford Site, Richland, Washington

WO/Job No.

Date: $09 / \overline{07 / 2000}$

Checked: $09 / 08 / 2000$

Revised
Calc. No. RPP-LJJ-004

Revision: 0

Page No. 10 of 34

Figure 4. Encased Pipe Guide. (H-14-102662)

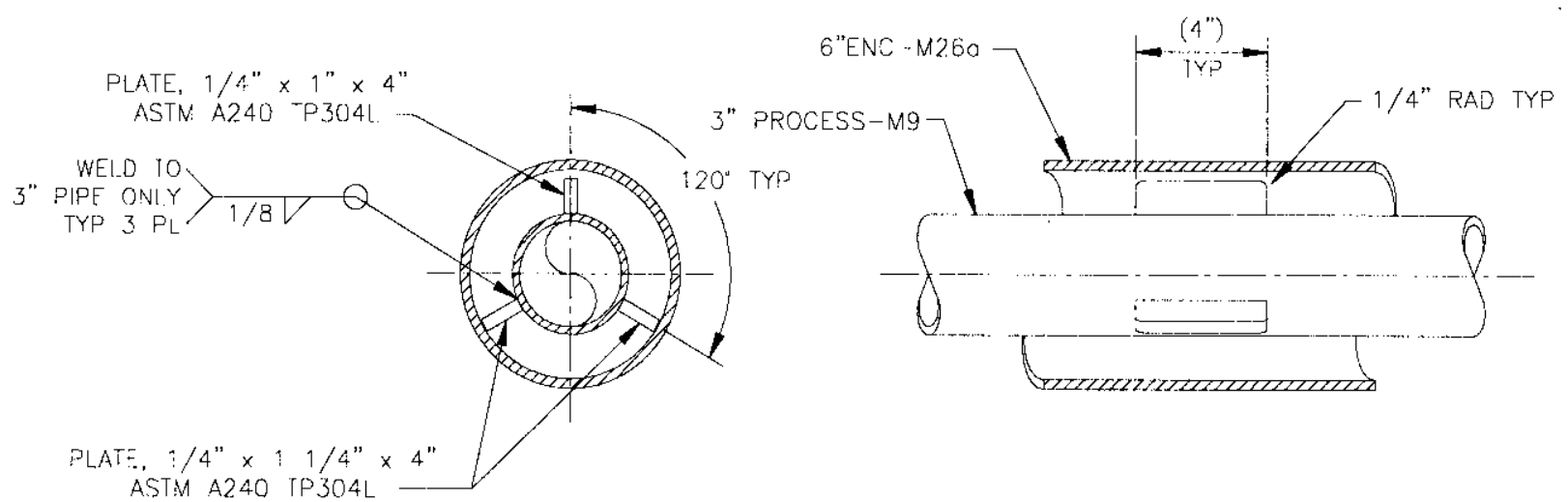


CH2MHILL Hanford Group, Inc.

RPP-6759 REV 0
Calc. No. RPP-LJJ-004

Revision: 0

Page No. 11 of 34

Client: $\quad$ CH2M Hill Hanford Group, Inc.

WO/Job No.

Subject: Secondary Encasement Pipe Pressure Due to Primary Pipe

Date: $09 / 07 / 2000$

Break in Waste Tank Transfer Piping System

Location: 200 Area - Hanford Site, Richland, Washington

By: L. J. Julyk

By:

Figure 5a. Encased Pipe Anchor. (H-14-102662)

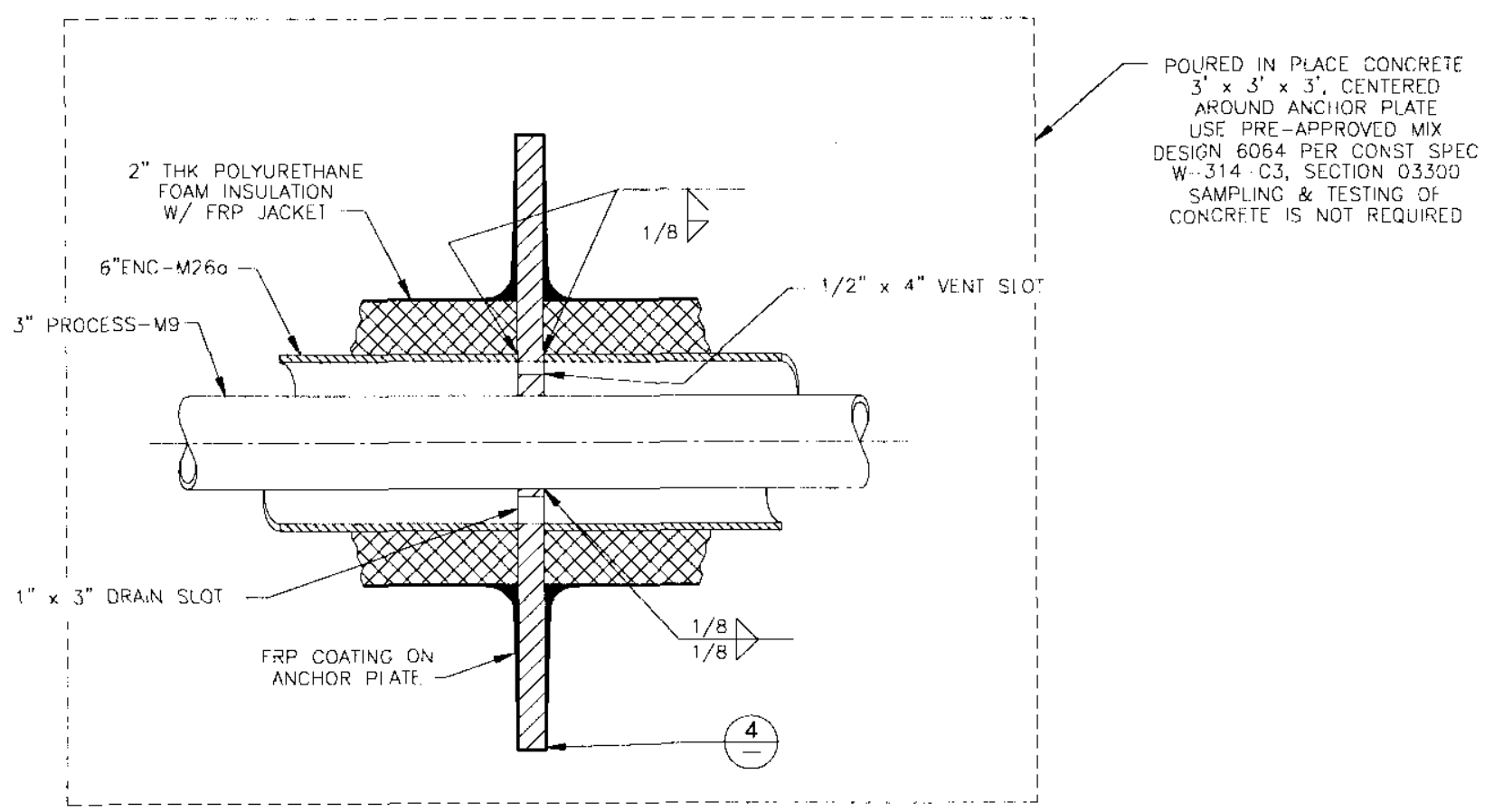


CH2MHILL Hanford Group, Inc.

EVALUATION ANALYSIS

Client: $\quad$ CH2M Hill Hanford Group, Inc.

Subject: Secondary Encasement Pipe Pressure Due to Primary Pipe

Break in Waste Tank Transfer Piping System

Location: 200 Area - Hanford Site, Richland, Washington
RPP-6759 REV 0

Calc. No. RPP-LJJ-004

Revision: 0

Page No. -12 of 34

WO/Job No.

Date: $09 / 07 / 2000$

Checked: $09 / 08 / 2000$

Revised:
By: L. J. Julyk

By: T. C. Oter

By:

Figure 5b. Encased Pipe Anchor. (H-14-102662)

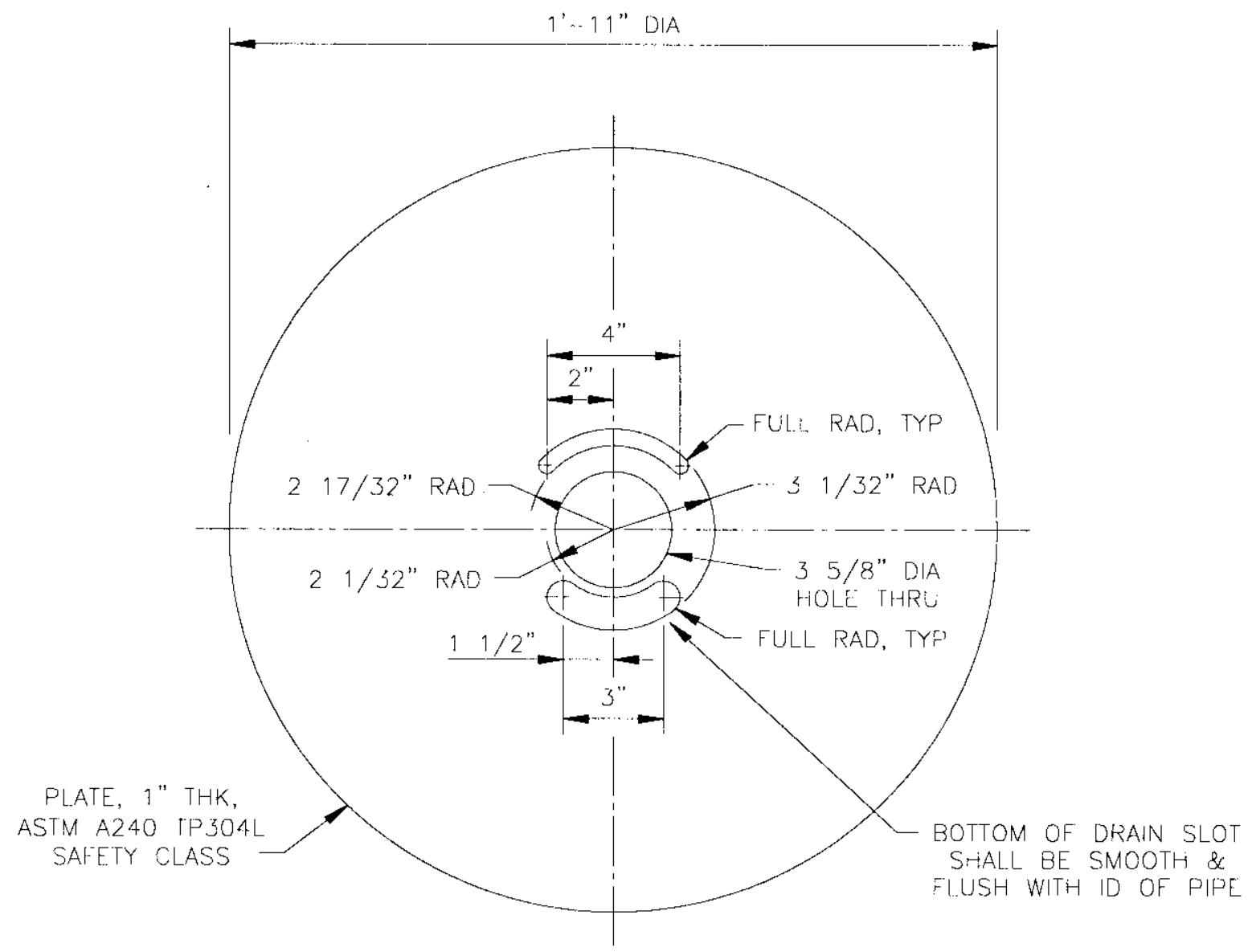




\section{CH2MHILL Hanford Group, Inc.}

\section{EVALUATION ANALYSIS}

Client: $\quad$ CH2M Hill Hanford Group, Inc.

Subject: Secondary Encasement Pipe Pressure Due to Primary Pipe Break in Waste Tank Transfer Piping System

Location: 200 Area - Hanford Site, Richland, Washington
Calc. No. RPP-LJJ-004

Revision: 0

Page No. 13 of 34

WO/Job No.

Date: $09 / \overline{07 / 2000} \quad \dot{B} y:$ L. J. Julyk

Checked: $09 / 08 / 2000$ By: T. C. Oten $\$$

Revised:

By:

Assume that pressure losses due to supports, guides or anchors can be approximated (first order approximation) from corresponding pressure losses due to a long hole orifice plate with equivalent hydraulic flow area.

K-resistance loss factor for a long hole orifice plate with upstream and downstream flow diameter D, center hole of diameter $D_{0}$, and plate thickness $L$ per Section 22, Eqn 4 of Lyons 1982 is applied to estimate the pressure loss from the pipe support, guide, and pipe anchor. The original equation is based on the flow velocity through the orifice and is recast herein in terms of the upstream flow velocity. First the correction factor accounting for plate thickness is given as

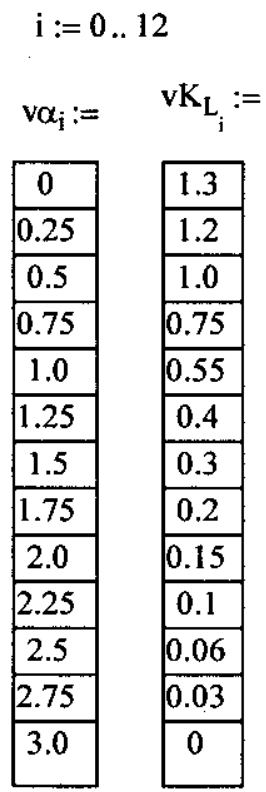

Correction Factor $\mathrm{K}_{\mathrm{L}}$

$$
\mathrm{K}_{\mathrm{L}}(\alpha):=\operatorname{linterp}\left(\mathrm{v} \alpha, \mathrm{vK}_{\mathrm{L}}, \alpha\right)
$$

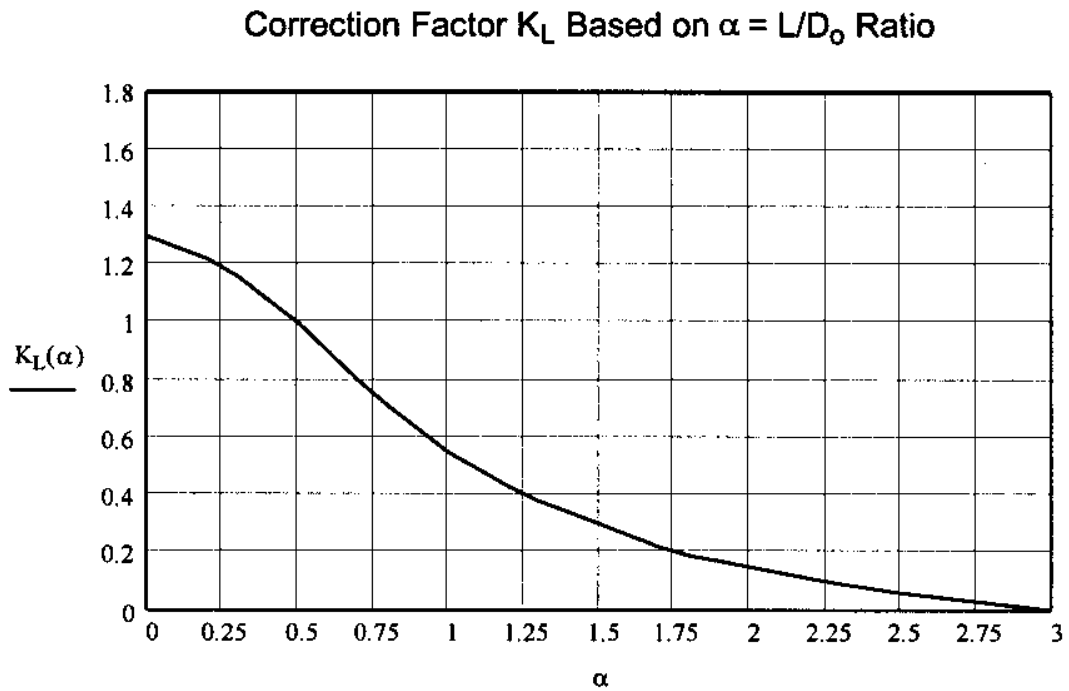

Resulting K-resistance loss factor for a long hole orifice plate based on upstream flow velocity becomes

$$
K(\beta, \alpha, \operatorname{Re}, \eta):=\frac{1}{\beta^{4}} \cdot\left[0.5 \cdot\left(1-\beta^{2}\right)+K_{L}(\alpha) \cdot \sqrt{1-\beta^{2}} \cdot\left(1-\beta^{2}\right)+\left(1-\beta^{2}\right)^{2}+f(\operatorname{Re}, \eta) \cdot \alpha\right]
$$

Pipe support in annulus region (Figure 3)

$$
\text { neglect effect of } 11 \mathrm{GA} \times 2^{\prime \prime} \times 6^{n} \text { rolled sheet }
$$

$\mathrm{t}:=\frac{1}{4} \cdot$ in

support plate thickness

$$
\begin{array}{ll}
\mathrm{A}:=\mathrm{A}_{\mathrm{S}}-\frac{1}{4} \cdot \text { in } \cdot\left(4+\frac{5}{16}\right) \cdot \text { in } & \mathrm{A}=18.191 \mathrm{in}^{2} \quad \text { flow area at pipe supports } \\
\mathrm{P}:=\mathrm{P}_{\mathrm{S}}+2 \cdot\left(4+\frac{5}{16}\right) \cdot \text { in } & \mathrm{P}=38.674 \mathrm{in} \quad \text { wetted perimeter } \\
\mathrm{D}_{\mathrm{H}_{-} \text {support }}:=4 \cdot \frac{\mathrm{A}}{\mathrm{P}} & \mathrm{D}_{\mathrm{H}_{-} \text {support }}=1.881 \text { in hydraulic diameter for pipe support guide }
\end{array}
$$


CH2MHILL Hanford Group, Inc.

RPP-6759 REV 0

\section{EVALUATION ANALYSIS}

Client: $\quad \mathrm{CH} 2 \mathrm{M}$ Hill Hanford Group, Inc.

Subject: Secondary Encasement Pipe Pressure Due to Primary Pipe Break in Waste Tank Transfer Piping System

Location: 200 Area - Hanford Site, Richland, Washington
WO/Job No.

Date: $09 / \overline{07 / 2000}$ Checked: $09 / 08 / 2000$ Revised
Calc. No. RPP-LJJ-004

Revision: 0

Page No. 14 of 34

$\beta_{\text {support }}:=\frac{D_{H_{-} \text {support }}}{D_{H_{-} \text {annulus }}} \quad \beta_{\text {support }}=0.734$

$L_{\text {support }}:=3 \cdot$ in length of support

$\alpha_{\text {support }}:=\frac{\mathrm{L}_{\text {support }}}{\mathrm{D}_{\mathrm{H}_{-} \text {support }}} \quad \alpha_{\text {support }}=1.595 \quad \mathrm{~K}_{\mathrm{L}}\left(\alpha_{\text {support }}\right)=0.262$

$\mathrm{K}_{\text {support }}\left(\mathrm{v}, \rho, \mathrm{t}_{\mathrm{C}}, \varepsilon\right):=K\left(\beta_{\text {support }}, \alpha_{\text {support }}, \frac{\mathrm{R}_{\mathrm{e}}\left(\mathrm{D}_{\mathrm{H}_{-} \text {annulus }}, \mathrm{v}, \rho, \mu\left(\rho, \mathrm{t}_{\mathrm{C}}\right)\right)}{\beta_{\text {support }}}, \frac{\varepsilon}{\mathrm{D}_{\mathrm{H}_{\_} \text {support }}}\right) \quad \rho=1.5 \frac{\mathrm{kg}}{\text { liter }}$

$\mathrm{K}_{\text {support }}\left(10 \cdot \frac{\mathrm{ft}}{\mathrm{sec}}, \rho, 10,50 \cdot \mathrm{mil}\right)=2.127 \quad \begin{aligned} & \text { Results for support at a flow velocity of } 10 \mathrm{ft} / \mathrm{s} \text {, liquid density of } 1.5 \mathrm{~kg} / \mathrm{L}, \\ & \text { temperature of } 10 \circ \mathrm{C} \text {, and pipe roughness of } 50 \text { mils. }\end{aligned}$

Pipe support guide in annulus region (Figure 4)

$\mathrm{t}:=\frac{1}{4} \cdot$ in

support plate thickness

$A:=A_{S}-3 \cdot t \cdot \frac{\left(D_{S i}-D_{P_{0}}\right)}{2}$

$A=18.307$ in $^{2} \quad$ flow area at pipe supports

$P:=P_{S}-6 \cdot t+6 \cdot \frac{\left(D_{S i}-D_{P_{0}}\right)}{2}$

$P=36.244$ in $\quad$ wetted perimeter

$\mathrm{D}_{\mathrm{H} \_ \text {guide }}:=4 \cdot \frac{\mathrm{A}}{\mathrm{P}}$

$\mathrm{D}_{\mathrm{H}_{-} \text {guide }}=2.02$ in hydraulic diameter for pipe support guide

$\beta_{\text {guide }}:=\frac{D_{H_{\text {guide }}}}{D_{\mathrm{H}_{\text {annulus }}}}$

$\beta_{\text {guide }}=0.788$

$\mathrm{L}_{\text {guide }}:=4 \cdot$ in length of guide

$\alpha_{\text {guide }}:=\frac{\mathrm{L}_{\text {guide }}}{\mathrm{D}_{\mathrm{H}_{\text {guide }}}} \quad \alpha_{\text {guide }}=1.98 \quad \mathrm{~K}_{\mathrm{L}}\left(\alpha_{\text {guide }}\right)=0.154$

$K_{\text {guide }}^{\prime}\left(v, \rho, t_{C}, \varepsilon\right):=K\left(\beta_{\text {guide }}, \alpha_{\text {guide }}, \frac{R_{e}\left(D_{H_{-} \text {annulus }}, v, \rho, \mu\left(\rho, t_{C}\right)\right)}{\beta_{\text {guide }}}, \frac{\varepsilon}{D_{H_{\text {_guide }}}}\right)$

$\mathrm{K}_{\text {guide }}^{\prime}\left(10 \cdot \frac{\mathrm{ft}}{\mathrm{sec}}, \rho, 10,50 \cdot \mathrm{mil}\right)=1.24$

Results for support guide at a flow velocity of $10 \mathrm{ft} / \mathrm{s}$, liquid density of $1.5 \mathrm{~kg} / \mathrm{L}$, temperature of $10^{\circ} \mathrm{C}$, and pipe roughness of 50 mils.

For simplicity, combining the pipe support resistance with every 4th guide, the effective K-resistance for the guide becomes

$K_{\text {guide }}\left(v, \rho, t_{C}, \varepsilon\right):=K_{\text {guide }}^{\prime}\left(v, \rho, t_{C}, \varepsilon\right)+\frac{1}{4} \cdot K_{\text {support }}\left(v, \rho, t_{C}, \varepsilon\right)$

$$
\mathrm{K}_{\text {guide }}\left(10 \cdot \frac{\mathrm{ft}}{\mathrm{sec}}, \rho, 10,50 \cdot \mathrm{mil}\right)=1.772
$$


CH2MHILL Hanford Group, Inc.

EVALUATION ANALYSIS

Client: $\quad$ CH2M Hill Hanford Group, Inc.

Subject: Secondary Encasement Pipe Pressure Due to Primary Pipe Break in Waste Tank Transfer Piping System

Location: 200 Area - Hanford Site, Richland, Washington
WO/Job No.

Date: $09 / 07 / 2000$ Checked: $09 / 08 / 2000$ Revised:
Calc. No. RPP-LJJ-004

Revision: 0

Page No. 15 of 34

Pipe anchor in annulus region (Figure 5)

$r_{1}:=\left(2+\frac{17}{32}\right) \cdot$ in $\quad t_{1}:=\frac{D_{S i}}{2}-r_{1} \quad L_{1}:=4 \cdot$ in $\quad \theta_{1}:=2 \cdot \operatorname{asin}\left[\frac{L_{1}}{\left(\frac{D_{S i}}{2}+r_{1}\right)}\right]$
$r_{1}=2.531$ in $\quad t_{1}=0.501$ in
$r_{2}:=\left(2+\frac{1}{32}\right) \cdot$ in $\quad t_{2}:=\frac{D_{S i}}{2}-r_{2} \quad L_{2}:=3 \cdot$ in $\quad \theta_{2}:=2 \cdot \operatorname{asin}\left[\frac{L_{2}}{\left(\frac{D_{S i}}{2}+r_{2}\right)}\right]$
$r_{2}=2.031$ in $\quad t_{2}=1.001$ in $\quad \theta_{2}=72.662$ deg $\quad A=6.437$ in ${ }^{2}$
$A:=\frac{\pi}{4} \cdot t_{1}{ }^{2}+\frac{\theta 1}{2} \cdot\left[\left(\frac{D_{S i}}{2}\right)^{2}-r_{1}{ }^{2}\right]+\frac{\pi}{4} \cdot t_{2}{ }^{2}+\frac{\theta_{2}}{2} \cdot\left[\left(\frac{D_{S i}}{2}\right)^{2}-r_{2}{ }^{2}\right] \quad$ flow area of pipe
$P:=\pi \cdot t_{1}+\theta_{1} \cdot\left(\frac{D_{S i}}{2}+r_{1}\right)+\pi \cdot t_{2}+\theta_{2} \cdot\left(\frac{D_{S i}}{2}+r_{2}\right) \quad 20.069$ in $\quad$ wetted perimeter

$\mathrm{D}_{\mathrm{H} \_ \text {anchor }}:=4 \cdot \frac{\mathrm{A}}{\mathrm{P}} \quad \mathrm{D}_{\mathrm{H} \_ \text {anchor }}=1.283$ in $\quad$ hydraulic diameter for anchor

$\beta_{\text {anchor }}:=\frac{\mathrm{D}_{\mathrm{H}_{\_} \text {anchor }}}{\mathrm{D}_{\mathrm{H}_{-} \text {annulus }}} \quad \beta_{\text {anchor }}=0.5 \quad \mathrm{~L}_{\text {anchor }}:=1 \cdot$ in $\quad \alpha_{\text {anchor }}:=\frac{\mathrm{L}_{\text {anchor }}}{\mathrm{D}_{\mathrm{H}_{\text {anchor }}}} \quad \alpha_{\text {anchor }}=0.779 \quad \mathrm{~K}_{\mathrm{L}}\left(\alpha_{\text {anchor }}\right)=0.726$

$K_{\text {anchor }}\left(v, \rho, t_{C}, \varepsilon\right):=K\left(\beta_{\text {anchor }}, \alpha_{\text {anchor }}, \frac{R_{e}\left(D_{H_{-} \text {annulus }}, v, \rho, \mu\left(\rho, t_{C}\right)\right)}{\beta_{\text {anchor }}}, \frac{\varepsilon}{D_{H_{-} \text {anchor }}}\right)$

$\mathrm{K}_{\text {anchor }}\left(10 \cdot \frac{\mathrm{ft}}{\mathrm{sec}}, \rho, 10,50 \cdot \mathrm{mil}\right)=23.32$

Results for anchor at a flow velocity of $10 \mathrm{ft} / \mathrm{s}$, liquid density of $1.5 \mathrm{~kg} / \mathrm{L}$, temperature of $10^{\circ} \mathrm{C}$, and pipe roughness of 50 mils. 
CH2MHILL Hanford Group, Inc.

RPP-6759 REV 0

EVALUATION ANALYSIS

Calc. No. RPP-LJJ-004

Revision: $\underline{0}$

Page No. 16 of 34

Client: $\quad$ CH2M Hill Hanford Group, Inc.

WO/Job No.

Subject: Secondary Encasement Pipe Pressure Due to Primary Pipe

Location: $\begin{array}{ll}\text { Break in Waste Tank Transfer Piping System } \\ \text { 200 Area-Hanford Site, Richland, Washington }\end{array}$

Date: $09 / \overline{07 / 2000}$ Checked: $09 / 08 / 2000$

Revised:

Bंy: L. J. Julyk

By: T. C. Oten

By:

Abrupt contraction from annulus region to drain pipe (Blevins 1984, Case 11 of Table 6-7 rewritten in terms of upstream flow velocity, see also CRANE 1988, Eqn 2-11)

$$
\begin{array}{lll}
\beta_{\mathrm{D}}\left(\mathrm{D}_{\mathrm{Di}}\right):=\frac{\mathrm{D}_{\mathrm{Di}}}{\mathrm{D}_{\mathrm{H}_{-} \text {annulus }}} & \text { 1-in. drain } & \begin{array}{l}
2 \text {-in. drain } \\
\beta_{\mathrm{D}}\left(\mathrm{D}_{\mathrm{D} 2 \mathrm{i}}\right)=0.806
\end{array} \\
\mathrm{~K}_{\mathrm{D}}\left(\mathrm{D}_{\mathrm{Di}}\right):=\frac{1}{2} \cdot\left(1-\mathrm{D}_{\mathrm{D} 1 \mathrm{D}}\left(\mathrm{D}_{\mathrm{Di}}\right)^{2}\right) \cdot \frac{1}{\beta_{\mathrm{D}}\left(\mathrm{D}_{\mathrm{Di}}\right)^{4}} & \mathrm{~K}_{\mathrm{D}}\left(\mathrm{D}_{\mathrm{Dli}}\right)=14.884 & \mathrm{~K}_{\mathrm{D}}\left(\mathrm{D}_{\mathrm{D} 2 \mathrm{i}}\right)=0.416
\end{array}
$$

Exit to atmosphere at drain (sudden enlargement, CRANE 1988, Eqn 2-9.1)

$$
K_{E}(\beta):=\left(1-\beta^{2}\right)^{2} \quad \beta:=0 \quad K_{E}:=K_{E}(\beta) \quad K_{E}=1
$$

Loss at break (RPP-5667, 2000)

Contraction coefficient for square edge orifice $C_{v}:=0.82$ and the velocity resistance $K_{v}$ is given by

$$
\mathrm{K}_{\mathrm{v}}\left(\mathrm{C}_{\mathrm{v}}\right):=\mathrm{C}_{\mathrm{v}}^{-2}-1 \quad \mathrm{~K}_{\mathrm{B}}:=\mathrm{K}_{\mathrm{v}}\left(\mathrm{C}_{\mathrm{v}}\right) \quad \mathrm{K}_{\mathrm{B}}=0.487
$$




\section{EVALUATION ANALYSIS}

Client: $\quad$ CH2M Hill Hanford Group, Inc.

Subject: Secondary Encasement Pipe Pressure Due to Primary Pipe Break in Waste Tank Transfer Piping System

Location: 200 Area - Hanford Site, Richland, Washington

WO/Job No.

By:

\section{Input Parameter Data}

\begin{tabular}{|c|c|}
\hline $\begin{array}{l}\text { down stream } \\
\text { of break }\end{array}$ & \\
\hline $\mathrm{L}_{\mathrm{i}}:=9 \cdot \mathrm{ft}$ & \multirow{2}{*}{$\begin{array}{l}\text { spacing of primary pipe guides } \\
\text { spacing parameter for anchors }\end{array}$} \\
\hline$\lambda:=12$ & \\
\hline $\mathrm{L}_{\mathrm{j}}:=\lambda \cdot \mathrm{L}_{\mathrm{i}}$ & spacing of primary pipe anchors \\
\hline \multicolumn{2}{|l|}{$\mathrm{L}_{\mathrm{j}}=108 \mathrm{ft}$} \\
\hline $\mathrm{L}_{\mathrm{D}}\left(\mathrm{D}_{\mathrm{Di}}\right):=3 \cdot \mathrm{ft}+3 \cdot 30 \cdot \mathrm{D}_{\mathrm{Di}}$ & approximate equivalent length of drain pipe including three standard $90^{\circ}$ elbov \\
\hline $\mathrm{D}_{\mathrm{Di}}$ & internal pipe diameter of drain \\
\hline$F_{D 6} \quad F_{D 9}$ & switch to block $(=0)$ or open $(=1)$ drain location 6 or 9 , respectively \\
\hline$\Delta Z_{\mathrm{D}}:=-1 \cdot \mathrm{ft}$ & approximate change in elevation at drain \\
\hline $\mathrm{L}_{\mathrm{P}}:=7000 \cdot \mathrm{ft}$ & total equivalent length of primary pipe from pump to discharge exit \\
\hline $\mathrm{Z}:=25 \cdot \mathrm{ft}$ & vertical increase in elevation at end of primary pipe at discharge to tank at WTP \\
\hline $\mathrm{H}:=0.25 \% \cdot \mathrm{L}_{\mathrm{P}}$ & \multirow[t]{2}{*}{$\begin{array}{l}\text { change in elevation of primary pipe from pump to point just before vertical } \\
\text { increase in elevation at end of primary pipe at discharge to tank (see Figure 1) }\end{array}$} \\
\hline $\mathrm{H}=17.5 \mathrm{ft}$ & \\
\hline $\mathrm{L}_{\mathrm{o}}:=1000 \cdot \mathrm{ft}$ & start distance from pump of secondary encasement section under consideration \\
\hline $\mathrm{L}_{\mathrm{S}}:=4000 \cdot \mathrm{ft}$ & length of secondary encasement section under consideration between drains \\
\hline$x_{B}:=200 \cdot f t+L_{0}$ & distance of break in primary pipe from pump \\
\hline$t_{C}$ & temperature of waste $\left({ }^{\circ} \mathrm{C}\right)$ \\
\hline$\rho$ & bulk density of waste $(\mathrm{kg} / \mathrm{L})$ \\
\hline
\end{tabular}

Determination of number of upstream and downstream support guides and anchors relative to break location for encasement section under consideration. Sample results given below are for above specified parameters. Actual values are calculated during solution as appropriate.

$$
J\left(L_{i}, L_{0}, x_{B}\right):=\left\{\begin{array}{l}
n \leftarrow \text { round }\left(\frac{x_{B}-L_{o}}{\lambda \cdot L_{i}}\right) \\
0 \text { if } n \leq 0 \\
n \text { otherwise }
\end{array}\right.
$$

number of anchors within secondary encasement section under consideration before break

$$
\mathrm{J}\left(\mathrm{L}_{\mathrm{i}}, \mathrm{L}_{\mathrm{o}}, \mathrm{x}_{\mathrm{B}}\right)=2
$$


CH2MHILL Hanford Group, Inc.

RPP-6759 REV 0

\section{EVALUATION ANALYSIS}

Client: $\quad$ CH2M Hill Hanford Group, Inc.

Subject: Secondary Encasement Pipe Pressure Due to Primary Pipe Break in Waste Tank Transfer Piping System

Location: 200 Area - Hanford Site, Richland, Washington
WO/Job No.

Date: $09 / 07 / 2000$ Checked: $09 / 08 / 2000$ Revised:
Calc. No. RPP-LJJ-004

Revision: 0

Page No. 18 of 34

$$
\begin{aligned}
& \mathrm{I}\left(\mathrm{L}_{\mathrm{i}}, \mathrm{L}_{\mathrm{o}}, \mathrm{x}_{\mathrm{B}}\right):=\mid \begin{array}{l}
\mathrm{n} \leftarrow \operatorname{round}\left(\frac{\mathrm{x}_{\mathrm{B}}-\mathrm{L}_{\mathrm{o}}}{\mathrm{L}_{\mathrm{i}}}-\mathrm{J}\left(\mathrm{L}_{\mathrm{i}}, \mathrm{L}_{\mathrm{o}}, \mathrm{x}_{\mathrm{B}}\right)\right) \\
0 \text { if } \mathrm{n} \leq 0 \\
\mathrm{n} \text { otherwise }
\end{array} \\
& \mathrm{N}\left(\mathrm{L}_{\mathrm{i}}, \mathrm{L}_{\mathrm{o}}, \mathrm{L}_{\mathrm{S}}, \mathrm{x}_{\mathrm{B}}\right):=\mid \begin{array}{l}
\mathrm{n} \leftarrow \text { round }\left[\frac{\mathrm{L}_{\mathrm{S}}-\left(\mathrm{x}_{\mathrm{B}}-\mathrm{L}_{\mathrm{o}}\right)}{\lambda \cdot \mathrm{L}_{\mathrm{i}}}\right] \\
0 \text { if } \mathrm{n} \leq 0 \\
\mathrm{n} \text { otherwise }
\end{array} \\
& \mathrm{M}\left(\mathrm{L}_{\mathrm{i}}, \mathrm{L}_{\mathrm{o}}, \mathrm{L}_{\mathrm{S}}, \mathrm{x}_{\mathrm{B}}\right):=\mid \begin{array}{l}
\mathrm{n} \leftarrow \text { round }\left[\frac{\mathrm{L}_{\mathrm{S}}-\left(\mathrm{x}_{\mathrm{B}}-\mathrm{L}_{\mathrm{o}}\right)}{\mathrm{L}_{\mathrm{i}}}-\mathrm{N}\left(\mathrm{L}_{\mathrm{i}}, \mathrm{L}_{\mathrm{o}}, \mathrm{L}_{\mathrm{S}}, \mathrm{x}_{\mathrm{B}}\right)\right. \\
0 \text { if } \mathrm{n} \leq 0 \\
\mathrm{n} \text { otherwise }
\end{array}
\end{aligned}
$$

number of support guides within secondary encasement section under consideration before break

$\mathrm{I}\left(\mathrm{L}_{\mathrm{i}}, \mathrm{L}_{\mathrm{o}}, \mathrm{x}_{\mathrm{B}}\right)=20$

number of anchors within secondary encasement section under consideration after break

$\mathrm{N}\left(\mathrm{L}_{\mathrm{i}}, \mathrm{L}_{\mathbf{0}}, \mathrm{L}_{\mathrm{S}}, \mathrm{x}_{\mathrm{B}}\right)=35$

number of support quides within secondary encasement section under consideration after break

$M\left(L_{i}, L_{0}, L_{S}, x_{B}\right)=387$

$$
\begin{aligned}
& \mathrm{g}=32.174 \mathrm{ftsec}^{-2} \\
& \mathrm{~V}_{\mathrm{z}}:=0 \cdot \mathrm{ft} \cdot \mathrm{sec}^{-1}
\end{aligned}
$$

Apply conservation of mass (continuity) and energy (Bernoulli theorem) between nodes (see Figure 1) and at the pipe break plus the characteristic pump head relation (see Figure 2) to model the nonlinear system of equations that govern the steady-state flow behavior resulting from a primary pipe break at location $x_{B}$ relative to pump.

$$
\begin{aligned}
& \text { Initial guesses } \quad \mathrm{Q}:=245 \cdot \mathrm{gpm} \quad \mathrm{V}_{1}:=\frac{\mathrm{Q}}{\mathrm{A}_{\mathrm{P}}} \quad \mathrm{V}_{1}=10.633 \frac{\mathrm{ft}}{\mathrm{sec}} \quad \text { flow velocities } \\
& \mathrm{D}_{\mathrm{Di}}:=\mathrm{D}_{\mathrm{D} 1 \mathrm{i}} \\
& \mathrm{H}_{\mathrm{P}}:=\mathrm{H}_{\mathrm{p}}^{\prime}\left(\mathrm{Q}, \mathrm{p}_{\mathrm{dh}}\right) \quad \text { pump head } \\
& \mathrm{p}_{2}:=100 \cdot \mathrm{psi} \text { primary pipe pressure just up stream of break } \\
& \mathrm{p}_{3}:=100 \cdot \mathrm{psi} \text { primary pipe pressure just down stream of break } \\
& \mathrm{p}_{5}:=100 \cdot \mathrm{psi} \text { secondary pipe pressure just up stream of break } \\
& \mathrm{p}_{6}:=50 \cdot \mathrm{psi} \quad \text { secondary pipe pressure at drain up stream of break } \\
& \mathrm{V}_{5}:=\frac{\mathrm{V}_{1}}{6} \\
& \mathrm{~F}_{\mathrm{D} 6}:=1 \\
& \mathrm{~F}_{\mathrm{D} 9}:=1 \\
& V_{6}:=V_{5} \cdot \frac{A_{S}}{A_{f}\left(D_{D i}\right)} \\
& \frac{A_{S}}{A_{P}}=2.607 \\
& V_{8}:=\frac{V_{1}}{6} \\
& \frac{A_{S}}{A_{f}\left(D_{D i}\right)}=22.296 \\
& \mathrm{p}_{8}:=100 \cdot \mathrm{psi} \text { secondary pipe pressure just down stream of break } \\
& p_{9}:=50 \cdot p s i \quad \text { secondary pipe pressure at drain down stream of break } \\
& \mathrm{V}_{9}:=\mathrm{V}_{8} \cdot \frac{\mathrm{A}_{S}}{\mathrm{~A}_{\mathrm{f}}\left(\mathrm{D}_{\mathrm{Di}}\right)} \\
& \text { apply conservation of mass } \\
& \text { (continuity) at break } \\
& V_{3}:=V_{1}-\frac{A_{S}}{A_{P}} \cdot\left(V_{5}+V_{8}\right) \quad V_{3}=1.395 \frac{f t}{\mathrm{sec}}
\end{aligned}
$$


CH2MHILL Hanford Group, Inc.

\section{EVALUATION ANALYSIS}

Client: $\quad$ CH2M Hill Hanford Group, Inc.

Subject: Secondary Encasement Pipe Pressure Due to Primary Pipe Break in Waste Tank Transfer Piping System

Location: 200 Area - Hanford Site, Richland, Washington
WO/Job No.

Date: $09 / \overline{07 / 2000}$ Checked: $09 / 08 / 2000$ Revised:
Calc. No. RPP-LJJ-004

Revision:

Page No. 19 of 34

\section{Nonlinear governing system of equations}

Given

apply conservation of mass (continuity) and energy (Bernoulli theorem)

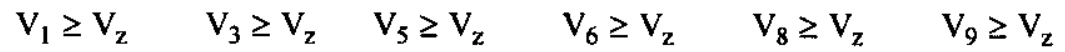

$A_{S} \cdot V_{5}=F_{D 6} \cdot A_{f}\left(D_{D i}\right) \cdot V_{6} \quad A_{S} \cdot V_{8}=F_{D 9} \cdot A_{f}\left(D_{D i}\right) \cdot V_{9} \quad A_{P} \cdot V_{3}=\left[A_{P} \cdot V_{1}-\left(A_{S} \cdot V_{5}+A_{S} \cdot V_{8}\right)\right]$

continuity

$H_{P}=H_{p}^{\prime}\left(A_{p} \cdot V_{1}, p_{d h}\right) \quad$ pump head curve

Bernoulli

(between nodes,

$\left(\frac{V_{1}^{2}}{2 \cdot g}+H_{P}-f\left(R_{e}\left(D_{P i}, V_{1}, \rho, \mu\left(\rho, t_{C}\right)\right), \frac{\varepsilon_{P}}{D_{P i}}\right) \cdot \frac{x_{B}}{D_{P i}} \cdot \frac{V_{1}^{2}}{2 \cdot g}\right)=\left(\frac{p_{2}}{\rho \cdot g}+\frac{V_{1}^{2}}{2 \cdot g}+x_{B} \cdot \frac{H}{L_{P}}\right)$

$\left(\frac{\mathrm{p}_{2}}{\rho \cdot \mathrm{g}}+\frac{\mathrm{V}_{1}^{2}}{2 \cdot \mathrm{g}}\right)=\left(\frac{\mathrm{p}_{3}}{\rho \cdot \mathrm{g}}+\frac{\mathrm{V}_{3}^{2}}{2 \cdot \mathrm{g}}\right)$

$\left(\frac{\mathrm{p}_{3}}{\rho \cdot \mathrm{g}}+\frac{\mathrm{V}_{3}^{2}}{2 \cdot \mathrm{g}}+\mathrm{x}_{\mathrm{B}} \cdot \frac{\mathrm{H}}{\mathrm{L}_{\mathrm{P}}}-\mathrm{f}\left(\mathrm{R}_{\mathrm{e}}\left(\mathrm{D}_{\mathrm{Pi}}, \mathrm{V}_{3}, \rho, \mu\left(\rho, \mathrm{t}_{\mathrm{C}}\right)\right), \frac{\varepsilon_{\mathrm{P}}}{\mathrm{D}_{\mathrm{Pi}}}\right) \cdot \frac{\mathrm{L}_{\mathrm{P}}-\mathrm{x}_{\mathrm{B}}}{\mathrm{D}_{\mathrm{Pi}}} \cdot \frac{\mathrm{V}_{3}{ }^{2}}{2 \cdot \mathrm{g}}-\mathrm{K}_{\mathrm{E}} \cdot \frac{\mathrm{V}_{3}{ }^{2}}{2 \cdot \mathrm{g}}\right)=\left(\frac{\mathrm{V}_{3}{ }^{2}}{2 \cdot \mathrm{g}}+\mathrm{L}_{\mathrm{P}} \cdot \frac{\mathrm{H}}{\mathrm{L}_{\mathrm{P}}}+\mathrm{Z}\right)$

$\left(\frac{\mathrm{p}_{2}}{\rho \cdot \mathrm{g}}+\frac{\mathrm{V}_{1}^{2}}{2 \cdot \mathrm{g}}-\mathrm{K}_{\mathrm{B}} \cdot \frac{\mathrm{V}_{5}^{2}}{2 \cdot \mathrm{g}}\right)=\left(\frac{\mathrm{p}_{5}}{\rho \cdot \mathrm{g}}+\frac{\mathrm{V}_{5}^{2}}{2 \cdot \mathrm{g}}\right)$

$\left(\begin{array}{l}\frac{\mathrm{p}_{5}}{\rho \cdot \mathrm{g}}+\frac{\mathrm{V}_{5}^{2}}{2 \cdot \mathrm{g}}+\mathrm{x}_{\mathrm{B}} \cdot \frac{\mathrm{H}}{\mathrm{L}_{\mathrm{P}}}-\mathrm{f}\left(\mathrm{R}_{\mathrm{e}}\left(\mathrm{D}_{\mathrm{H}_{-} \text {annulus }}, \mathrm{V}_{5}, \rho, \mu\left(\rho, \mathrm{t}_{\mathrm{C}}\right)\right), \frac{\varepsilon_{\mathrm{S}}}{\mathrm{D}_{\mathrm{H} \_ \text {annulus }}}\right) \cdot \frac{\mathrm{x}_{\mathrm{B}}-\mathrm{L}_{\mathrm{o}}}{\mathrm{D}_{\mathrm{H}_{-} \text {annulus }}} \cdot \frac{\mathrm{V}_{5}^{2}}{2 \cdot \mathrm{g}} \ldots \\ +-\mathrm{I}\left(\mathrm{L}_{\mathrm{i}}, \mathrm{L}_{\mathrm{o}}, \mathrm{x}_{\mathrm{B}}\right) \cdot \mathrm{K}_{\text {guide }}\left(\mathrm{V}_{5}, \rho, \mathrm{t}_{\mathrm{C}}, \varepsilon_{\mathrm{S}}\right) \cdot \frac{\mathrm{V}_{5}^{2}}{2 \cdot \mathrm{g}}-\mathrm{J}\left(\mathrm{L}_{\mathrm{i}}, \mathrm{L}_{\mathrm{o}}, \mathrm{x}_{\mathrm{B}}\right) \cdot \mathrm{K}_{\text {anchor }}\left(\mathrm{V}_{5}, \rho, \mathrm{t}_{\mathrm{C}}, \varepsilon_{\mathrm{S}}\right) \cdot \frac{\mathrm{V}_{5}^{2}}{2 \cdot \mathrm{g}}-\mathrm{K}_{\mathrm{D}}\left(\mathrm{D}_{\mathrm{Di}}\right) \cdot \frac{\mathrm{V}_{5}^{2}}{2 \cdot \mathrm{g}}\end{array}\right)=\left(\begin{array}{l}\frac{\mathrm{p}_{6}}{\rho \cdot \mathrm{g}}+\frac{\mathrm{V}_{6}^{2}}{2 \cdot \mathrm{g}} \ldots \\ +\mathrm{L}_{\mathrm{o}} \cdot \frac{\mathrm{H}}{\mathrm{L}_{\mathrm{P}}}\end{array}\right)$

$\left(\frac{p_{6}}{\rho \cdot g}+\frac{V_{6}^{2}}{2 \cdot g}-f\left(R_{e}\left(D_{D i}, V_{6}, \rho, \mu\left(\rho, t_{C}\right)\right), \frac{\varepsilon_{D}}{D_{D i}}\right) \cdot \frac{L_{D}\left(D_{D i}\right)}{D_{D i}} \cdot \frac{V_{6}^{2}}{2 \cdot g}-K_{E} \cdot \frac{V_{6}^{2}}{2 \cdot g}\right)=\frac{V_{6}^{2}}{2 \cdot g}+\Delta Z_{D}$

$\left(\frac{\mathrm{p}_{2}}{\rho \cdot \mathrm{g}}+\frac{\mathrm{V}_{1}^{2}}{2 \cdot \mathrm{g}}-\mathrm{K}_{\mathrm{B}} \cdot \frac{\mathrm{V}_{8}^{2}}{2 \cdot \mathrm{g}}\right)=\left(\frac{\mathrm{p}_{8}}{\rho \cdot \mathrm{g}}+\frac{\mathrm{V}_{8}^{2}}{2 \cdot \mathrm{g}}\right)$

$\left[\begin{array}{l}\frac{\mathrm{p}_{8}}{\rho \cdot g}+\frac{\mathrm{V}_{8}^{2}}{2 \cdot g}+\mathrm{x}_{\mathrm{B}} \cdot \frac{\mathrm{H}}{\mathrm{L}_{\mathrm{P}}}-\mathrm{f}\left(\mathrm{R}_{\mathrm{e}}\left(\mathrm{D}_{\mathrm{H}_{-} \text {annulus }}, \mathrm{V}_{8}, \rho, \mu\left(\rho, \mathrm{t}_{\mathrm{C}}\right)\right), \frac{\varepsilon_{\mathrm{S}}}{\mathrm{D}_{\mathrm{H}_{-} \text {annulus }}}\right) \cdot \frac{\mathrm{L}_{\mathrm{S}}-\left(\mathrm{x}_{\mathrm{B}}-\mathrm{L}_{\mathrm{o}}\right)}{\mathrm{D}_{\mathrm{H}_{-} \text {annulus }}} \cdot \frac{\mathrm{V}_{8}{ }^{2}}{2 \cdot \mathrm{g}} \ldots \\ +-\mathrm{M}\left(\mathrm{L}_{\mathrm{i}}, \mathrm{L}_{\mathrm{o}}, \mathrm{L}_{\mathrm{S}}, \mathrm{x}_{\mathrm{B}}\right) \cdot \mathrm{K}_{\text {guide }}\left(\mathrm{V}_{8}, \rho, \mathrm{t}_{\mathrm{C}}, \varepsilon_{\mathrm{S}}\right) \cdot \frac{\mathrm{V}_{8}{ }^{2}}{2 \cdot \mathrm{g}} \ldots\end{array}\right]=\left[\begin{array}{l}\frac{\mathrm{p}_{9}}{\rho \cdot \mathrm{g}}+\frac{\mathrm{V}_{9}{ }^{2}}{2 \cdot \mathrm{g}} \ldots \\ +\left(\mathrm{L}_{\mathrm{S}}+\mathrm{L}_{\mathrm{o}}\right) \cdot \frac{\mathrm{H}}{\mathrm{L}_{\mathrm{P}}}\end{array}\right]$

$+-\mathrm{N}\left(\mathrm{L}_{\mathrm{i}}, \mathrm{L}_{\mathrm{o}}, \mathrm{L}_{\mathrm{S}}, \mathrm{x}_{\mathrm{B}}\right) \cdot \mathrm{K}_{\text {anchor }}\left(\mathrm{V}_{8}, \rho, \mathrm{t}_{\mathrm{C}}, \varepsilon_{\mathrm{S}}\right) \cdot \frac{\mathrm{V}_{8}^{2}}{2 \cdot \mathrm{g}}-\mathrm{K}_{\mathrm{D}}\left(\mathrm{D}_{\mathrm{Di}}\right) \cdot \frac{\mathrm{V}_{8}{ }^{2}}{2 \cdot \mathrm{g}}$

$\left(\frac{p_{9}}{\rho \cdot g}+\frac{V_{9}^{2}}{2 \cdot g}-f\left(R_{e}\left(D_{D i}, V_{9}, \rho, \mu\left(\rho, t_{C}\right)\right), \frac{\varepsilon_{D}}{D_{D i}}\right) \cdot \frac{L_{D}\left(D_{D i}\right)}{D_{D i}} \cdot \frac{V_{9}^{2}}{2 \cdot g}-K_{E} \cdot \frac{V_{9}^{2}}{2 \cdot g}\right)=\frac{V_{9}{ }^{2}}{2 \cdot g}+\Delta Z_{D}$ 


\section{CH2MHILL Hanford Group, Inc.}

RPP-6759 REV 0

\section{EVALUATION ANALYSIS}

Client: $\quad$ CH2M Hill Hanford Group, Inc.

Subject: Secondary Encasement Pipe Pressure Due to Primary Pipe Break in Waste Tank Transfer Piping System

Location: 200 Area - Hanford Site, Richland, Washington
WO/Job No.

Date: $09 / \overline{07 / 2000}$ Checked: $09 / 08 / 2000$ Revised:
Calc. No. RPP-LJJ-004

Revision: 0

Page No. 20 of 34
By: L. J. Julyk

By: T.C. Oterneo

By:

\section{Solution function}

$\mathrm{ff}\left(\mathrm{L}_{\mathrm{o}}, \mathrm{L}_{\mathrm{S}}, \mathrm{x}_{\mathrm{B}}, \rho, \mathrm{t}_{\mathrm{C}}, \mathrm{p}_{\mathrm{dh}}, \varepsilon_{\mathrm{P}}, \varepsilon_{\mathrm{S}}, \varepsilon_{\mathrm{D}}, \mathrm{D}_{\mathrm{Di}}, \mathrm{F}_{\mathrm{D}}, \mathrm{F}_{\mathrm{D} 9}, \Delta \mathrm{Z}_{\mathrm{D}}, \mathrm{L}_{\mathrm{P}}, \mathrm{H}, \mathrm{Z}\right):=\mathrm{Find}\left(\mathrm{H}_{\mathrm{P}}, \mathrm{p}_{2}, \mathrm{p}_{3}, \mathrm{p}_{5}, \mathrm{p}_{6}, \mathrm{p}_{8}, \mathrm{p}_{9}, \mathrm{~V}_{1}, \mathrm{~V}_{3}, \mathrm{~V}_{5}, \mathrm{~V}_{6}, \mathrm{~V}_{8}, \mathrm{~V}_{9}\right)$

For plotting, following function returns nth solution variable at points defined in vector $x_{B} \quad n=$ result variable selected

$$
\operatorname{PP}\left(\mathrm{L}_{\mathrm{o}}, \mathrm{L}_{\mathrm{S}}, \mathrm{x}_{\mathrm{B}}, \rho, \mathrm{t}_{\mathrm{C}}, \mathrm{p}_{\mathrm{dh}}, \varepsilon_{\mathrm{P}}, \varepsilon_{\mathrm{S}}, \varepsilon_{\mathrm{D}}, \mathrm{D}_{\mathrm{Di}}, \mathrm{F}_{\mathrm{D} 6}, \mathrm{~F}_{\mathrm{D} g}, \Delta \mathrm{Z}_{\mathrm{D}}, \mathrm{L}_{\mathrm{P}}, \mathrm{H}, \mathrm{Z}, \mathrm{n}\right):=\mid \begin{aligned}
& \mathrm{vp} \leftarrow 0 \\
& \text { for } \mathrm{i} \in 0 . . \operatorname{length}\left(\mathrm{x}_{\mathrm{B}}\right)-1 \\
& \mid \begin{array}{l}
\mathrm{x}_{\mathrm{BB}} \leftarrow \mathrm{x}_{\mathrm{B}} \\
\mathrm{p} \leftarrow 0 \\
\mathrm{p} \leftarrow \mathrm{ff}\left(\mathrm{L}_{\mathrm{o}}, \mathrm{L}_{\mathrm{S}}, \mathrm{x}_{\mathrm{BB}}, \rho, \mathrm{t}_{\mathrm{C}}, \mathrm{p}_{\mathrm{dh}}, \varepsilon_{\mathrm{P}}, \varepsilon_{\mathrm{S}}, \varepsilon_{\mathrm{D}}, \mathrm{D}_{\mathrm{Di}}, \mathrm{F}_{\mathrm{D} 6}, \mathrm{~F}_{\mathrm{D} g}, \Delta \mathrm{Z}_{\mathrm{D}}, \mathrm{L}_{\mathrm{P}},\right. \\
\mathrm{vp} \mathrm{p}_{\mathrm{i}} \leftarrow \mathrm{p}_{\mathrm{n}, 0}
\end{array}
\end{aligned}
$$




\section{CH2MHILL Hanford Group, Inc.}

EVALUATION ANALYSIS

Client: $\quad$ CH2M Hill Hanford Group, Inc.

Subject: Secondary Encasement Pipe Pressure Due to Primary Pipe Break in Waste Tank Transfer Piping System

Location: 200 Area - Hanford Site, Richland, Washington
Calc. No. RPP-LJJ-004

Revision: 0

Page No. 21 of 34

WO/Job No.

Date: $09 / 07 / 2000$ Checked: $09 / 08 / 2000$ Revised:
By: L. J. Julyk

By: T. C. Otern,eo

By:

\section{Two Drain Case - 1-in. Drain}

\begin{tabular}{|c|c|c|c|c|c|}
\hline \multicolumn{6}{|c|}{ 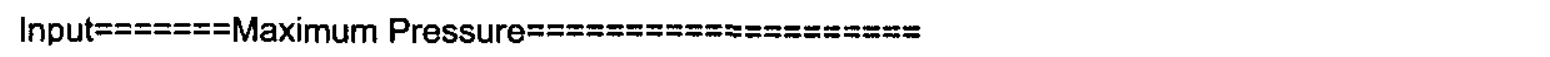 } \\
\hline $\mathrm{L}_{\mathrm{o}}:=0 \cdot \mathrm{ft}$ & $\mathrm{p}_{\mathrm{dh}}:=650 \cdot \mathrm{psi}$ & $\mathrm{H}=17.5 \mathrm{ft}$ & $\varepsilon_{\mathrm{P}}:=2 \cdot \mathrm{mil}$ & & \\
\hline $\mathrm{L}_{\mathrm{S}}:=4000 \cdot \mathrm{ft}$ & $\mathrm{o}:=1.5 . \underline{\mathrm{kg}}$ & $\mathrm{Z}:=25 \cdot \mathrm{ft}$ & $\varepsilon_{\mathrm{S}}:=50 \cdot \mathrm{mil}$ & & \\
\hline$L_{P}:=7000 \cdot f t$ & liter & $F_{D 6}:=1$ & $\varepsilon_{D}:=50 \cdot \mathrm{mil}$ & & \\
\hline $\mathrm{x}_{\mathrm{B}}:=0 \cdot \mathrm{ft}+\mathrm{L}_{\mathrm{o}}$ & $t_{C}:=10^{\circ} \mathrm{C}$ & $\mathrm{F}_{\mathrm{D} 9}:=1$ & $\mathrm{D}_{\mathrm{Di}}:=\mathrm{D}_{\mathrm{D} 1 \mathrm{i}}$ & $\Delta Z_{D}=-1 \mathrm{ft}$ & $L_{D}\left(D_{D i}\right)=10.867 f t$ \\
\hline
\end{tabular}

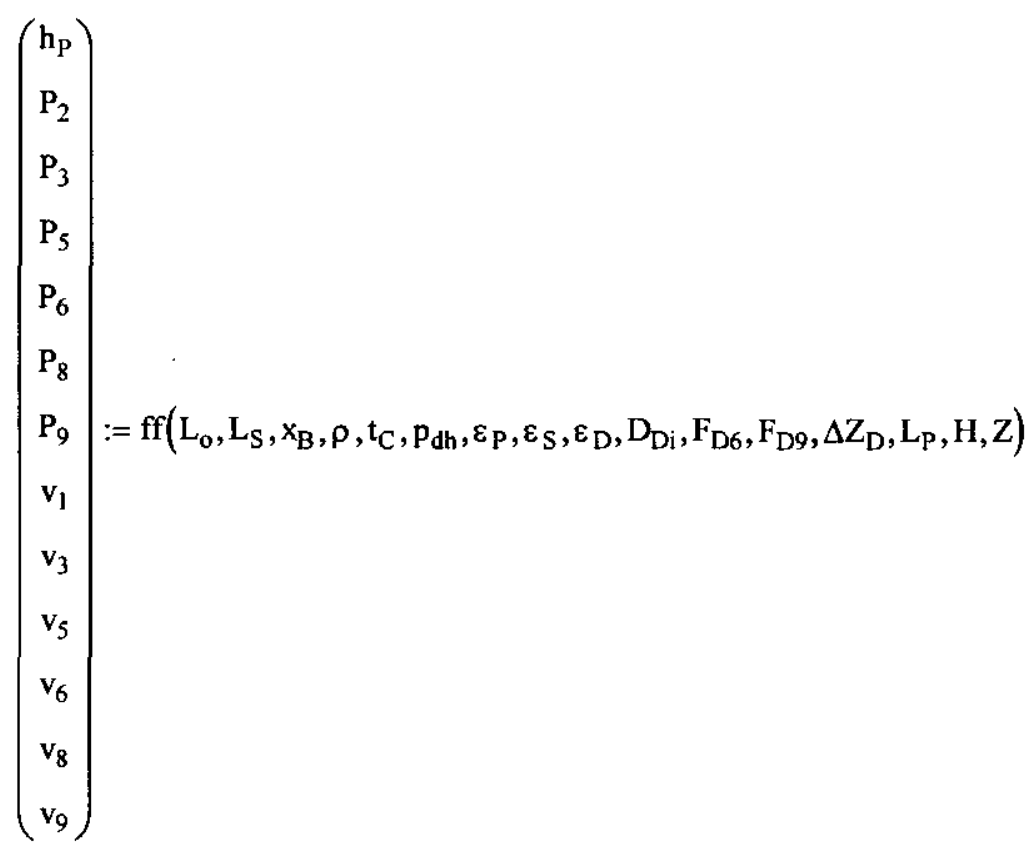

Results-

$$
\begin{aligned}
& \mathrm{h}_{\mathrm{P}}=213.4 \mathrm{ft} \quad \mathrm{H}_{\mathrm{P}}^{\prime}\left(\mathrm{A}_{\mathrm{P}} \cdot \mathrm{v}_{1}, \mathrm{p}_{\mathrm{dh}}\right)=213.4 \mathrm{ft} \quad \mu_{\mathrm{t}}:=\mu\left(\rho, \mathrm{t}_{\mathrm{C}}\right) \quad \mu_{\mathrm{t}}=11.708 \mathrm{cP} \quad \mathrm{L}_{\mathrm{i}}=9 \mathrm{ft} \quad \mathrm{L}_{\mathrm{j}}=108 \mathrm{ft} \quad \mathrm{D}_{\mathrm{Di}}=1.049 \mathrm{in}
\end{aligned}
$$

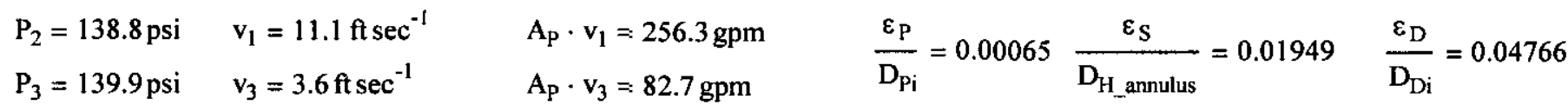

$$
\begin{aligned}
& P_{5}=140 \mathrm{psi} \quad \mathrm{v}_{5}=1.6 \mathrm{ftsec}^{-1} \quad \mathrm{~A}_{\mathrm{S}} \cdot \mathrm{v}_{5}=96.4 \mathrm{gpm} \\
& P_{6}=126.7 \mathrm{psi} \quad v_{6}=35.8 \mathrm{ftsec}^{-1} \quad \mathrm{~F}_{\mathrm{D} 6} \cdot \mathrm{A}_{\mathrm{f}}\left(\mathrm{D}_{\mathrm{Di}}\right) \cdot \mathrm{v}_{6}=96.4 \mathrm{gpm} \\
& \mathrm{P}_{8}=140 \mathrm{psi} \quad \mathrm{v}_{8}=1.3 \mathrm{ft} \mathrm{sec}^{-1} \quad \mathrm{~A}_{\mathrm{S}} \cdot \mathrm{v}_{8}=77.1 \mathrm{gpm} \\
& \mathrm{P}_{9}=81 \mathrm{psi} \quad \mathrm{v}_{9}=28.6 \mathrm{ft} \mathrm{sec}^{-1} \quad \mathrm{~F}_{\mathrm{D} 9} \cdot \mathrm{A}_{\mathrm{f}}\left(\mathrm{D}_{\mathrm{Di}}\right) \cdot \mathrm{v}_{9}=77.1 \mathrm{gpm} \\
& v_{1} \cdot A_{P}=A_{P} \cdot v_{3}+A_{S} \cdot v_{5}+A_{S} \cdot v_{8}=256.3 \mathrm{gpm} \\
& \text { (continuity check at break, } \mathrm{OK} \text { ) }
\end{aligned}
$$


CH2MHILL Hanford Group, Inc.
Client: $\quad$ CH2M Hill Hanford Group, Inc.

Subject: Secondary Encasement Pipe Pressure Due to Primary Pipe Break in Waste Tank Transfer Piping System

Location: 200 Area - Hanford Site, Richland, Washington
WO/Job No.

Date: $09 / 07 / 2000$ Checked: $09 / 08 / 2000$ Revised:
Calc. No. RPP-LJJ-004

Revision: 0

Page No. $\underline{22}$ of 34

By: L. J. Julvk

By: T. C. Otenco

By:

Figure 6a. Maximum Pressure in Secondary Encasement Pipe Due to Primary Pipe Break within Encasement Section with Two 1-in. Drains in Encasement Section of Length $L_{s}$

Starting at $L_{o}=0 \mathrm{ft}$ Relative to Pump and for a Waste Temperature of $10^{\circ} \mathrm{C}$.

$\begin{array}{llllllll}\mathrm{Z}=25 \mathrm{ft} & \mathrm{p}_{\mathrm{dh}}=650 \mathrm{psi} & \rho=1.5 \frac{\mathrm{kg}}{\text { liter }} & \mu\left(\rho, \mathrm{t}_{\mathrm{C}}\right)=11.708 \mathrm{cP} & \varepsilon_{\mathrm{P}}=2 \mathrm{mil} & \varepsilon_{\mathrm{S}}=50 \mathrm{mil} & \varepsilon_{\mathrm{D}}=50 \mathrm{mil} & \mathrm{F}_{\mathrm{D} 6}=1 \\ \mathrm{H}=17.5 \mathrm{ft} & \mathrm{t}_{\mathrm{C}}=10 \mathrm{l} \mathrm{C} & \mathrm{L}_{\mathrm{o}}=0 \mathrm{ft} & \mathrm{L}_{\mathrm{P}}=7000 \mathrm{ft} & \mathrm{L}_{\mathrm{i}}=9 \mathrm{ft} & \mathrm{L}_{\mathrm{j}}=108 \mathrm{ft} & \mathrm{D}_{\mathrm{Di}}=1.049 \mathrm{in} & \mathrm{F}_{\mathrm{D} 9}=1 \\ \Delta \mathrm{Z}_{\mathrm{D}}=-1 \mathrm{ft} & & & & & & \mathrm{L}_{\mathrm{D}}\left(\mathrm{D}_{\mathrm{Di}}\right)=10.9 \mathrm{ft} & \end{array}$

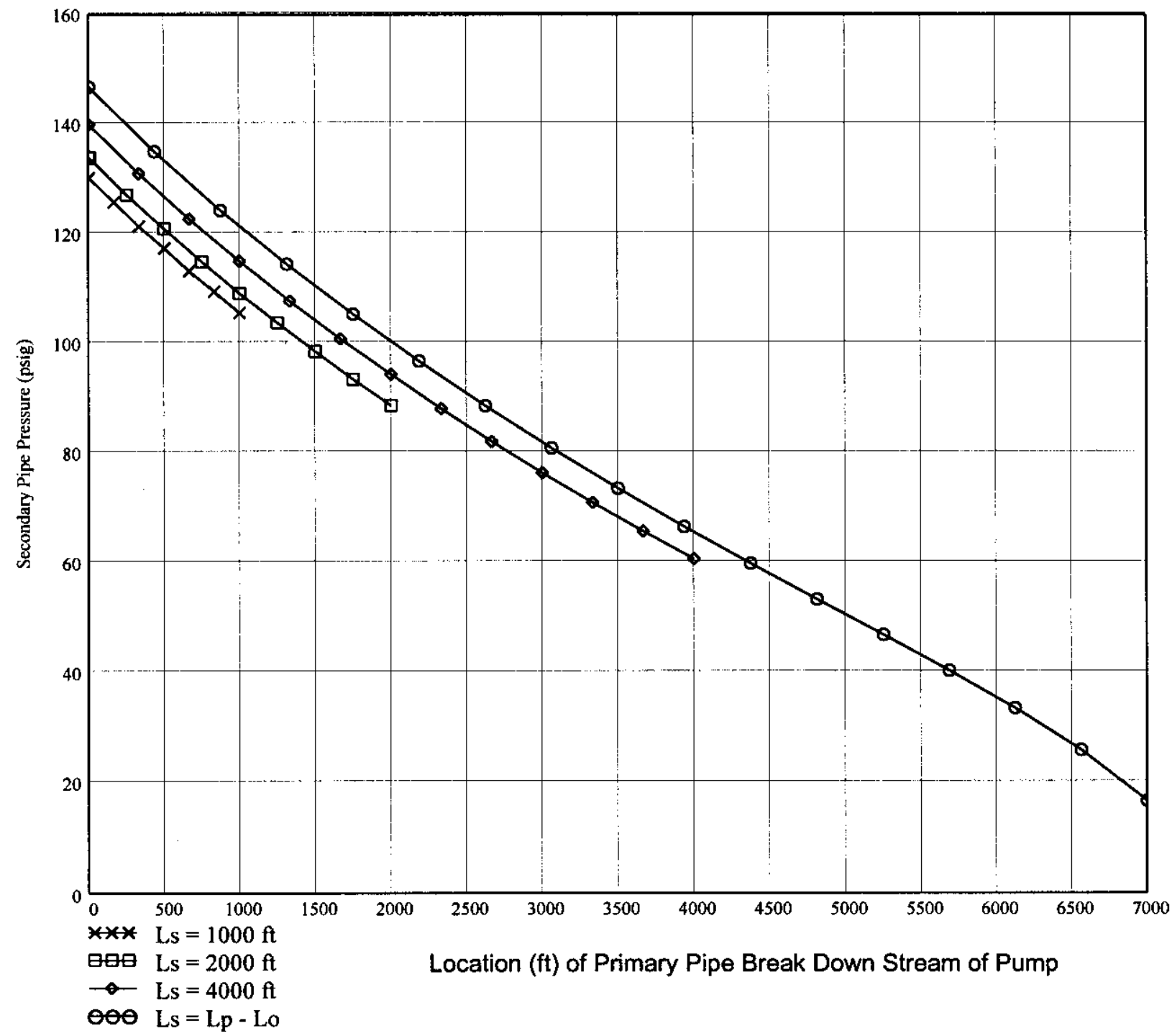


CH2MHILL Hanford Group, Inc.

\section{EVALUATION ANALYSIS}

Client: $\quad$ CH2M Hill Hanford Group, Inc.

Subject: Secondary Encasement Pipe Pressure Due to Primary Pipe Break in Waste Tank Transfer Piping System

Location: 200 Area - Hanford Site, Richland, Washington

\section{RPP-6759 REV 0}

Calc. No. RPP-LJJ-004

Revision: 0

Page No. -23 of 34

WO/Job No.

Date: $09 / \overline{07 / 2000}$ Checked: $09 / 08 / 2000$ Revised:
Bंy: L. J. Julyk

By: T. C. Oter $<0$

By:

\section{Effect of Waste Temperature}

$$
\begin{aligned}
& \operatorname{TT}\left(\mathrm{L}_{\mathrm{o}}, \mathrm{L}_{\mathrm{S}}, \mathrm{x}_{\mathrm{B}}, \rho, \mathrm{t}_{\mathrm{C}}, \mathrm{P}_{\mathrm{dh}}, \varepsilon_{\mathrm{P}}, \varepsilon_{\mathrm{S}}, \varepsilon_{\mathrm{D}}, \mathrm{D}_{\mathrm{Di}}, \mathrm{F}_{\mathrm{D} 6}, \mathrm{~F}_{\mathrm{D} 9}, \Delta \mathrm{Z}_{\mathrm{D}}, \mathrm{L}_{\mathrm{P}}, \mathrm{H}, \mathrm{Z}, \mathrm{n}\right):=\mid \mathrm{vp} \leftarrow 0 \\
& \text { for } i \in 0 \text {.. length }\left(t_{c}\right)-1 \\
& \mid \begin{array}{l}
\mathrm{t}_{\mathrm{CC}} \leftarrow \mathrm{t}_{\mathrm{C}_{\mathrm{i}}} \\
\mathrm{p} \leftarrow 0
\end{array} \\
& \mathrm{p} \leftarrow \mathrm{ff}\left(\mathrm{L}_{\mathbf{o}}, \mathrm{L}_{\mathrm{S}}, \mathrm{x}_{\mathrm{B}}, \rho, \mathrm{t}_{\mathrm{CC}}, \mathrm{p}_{\mathrm{dh}}, \varepsilon_{\mathrm{P}}, \varepsilon_{\mathrm{S}}, \varepsilon_{\mathrm{D}}, \mathrm{D}_{\mathrm{Di}}, \mathrm{F}_{\mathrm{D} 6}, \mathrm{~F}_{\mathrm{D} g}, \Delta \mathrm{Z}_{\mathrm{D}}, \mathrm{L}_{\mathrm{P}}\right. \\
& \mathrm{vp}_{\mathrm{i}} \leftarrow \mathrm{p}_{\mathrm{n}, 0}
\end{aligned}
$$

Figure 6b. Pressure in Secondary Encasement Pipe as a Function of Waste Temperature Due to Primary Pipe Break at $x_{B}$ within Encasement Section with Two 1-in. Drains in Encasement Section of Length $L_{s}$ Starting at $L_{0}$ Relative to Pump.

$$
\begin{aligned}
& \mathrm{Z}=25 \mathrm{ft} \quad \mathrm{P}_{\mathrm{dh}}=650 \mathrm{psi} \quad \rho=1.5 \frac{\mathrm{kg}}{\text { liter }} \quad \varepsilon_{\mathrm{P}}=2 \mathrm{mil} \quad \varepsilon_{\mathrm{S}}=50 \mathrm{mil} \quad \varepsilon_{\mathrm{D}}=50 \mathrm{mil} \\
& \mathrm{H}=17.5 \mathrm{ft} \quad \mathrm{L}_{\mathrm{S}}=4000 \mathrm{ft} \quad \mathrm{L}_{\mathrm{o}}=0 \mathrm{ft} \quad \mathrm{L}_{\mathrm{P}}=7000 \mathrm{ft} \quad \mathrm{L}_{\mathrm{i}}=9 \mathrm{ft} \quad \mathrm{L}_{\mathrm{j}}=108 \mathrm{ft} \quad \mathrm{x}_{\mathrm{B}}=0 \mathrm{ft} \\
& \mathrm{D}_{\mathrm{Di}}=1.049 \mathrm{in} \quad \mathrm{F}_{\mathrm{D} 9}=1 \\
& \Delta \mathrm{Z}_{\mathrm{D}}=-1 \mathrm{ft} \\
& \mathrm{L}_{\mathrm{D}}\left(\mathrm{D}_{\mathrm{Di}}\right)=10.9 \mathrm{ft}
\end{aligned}
$$

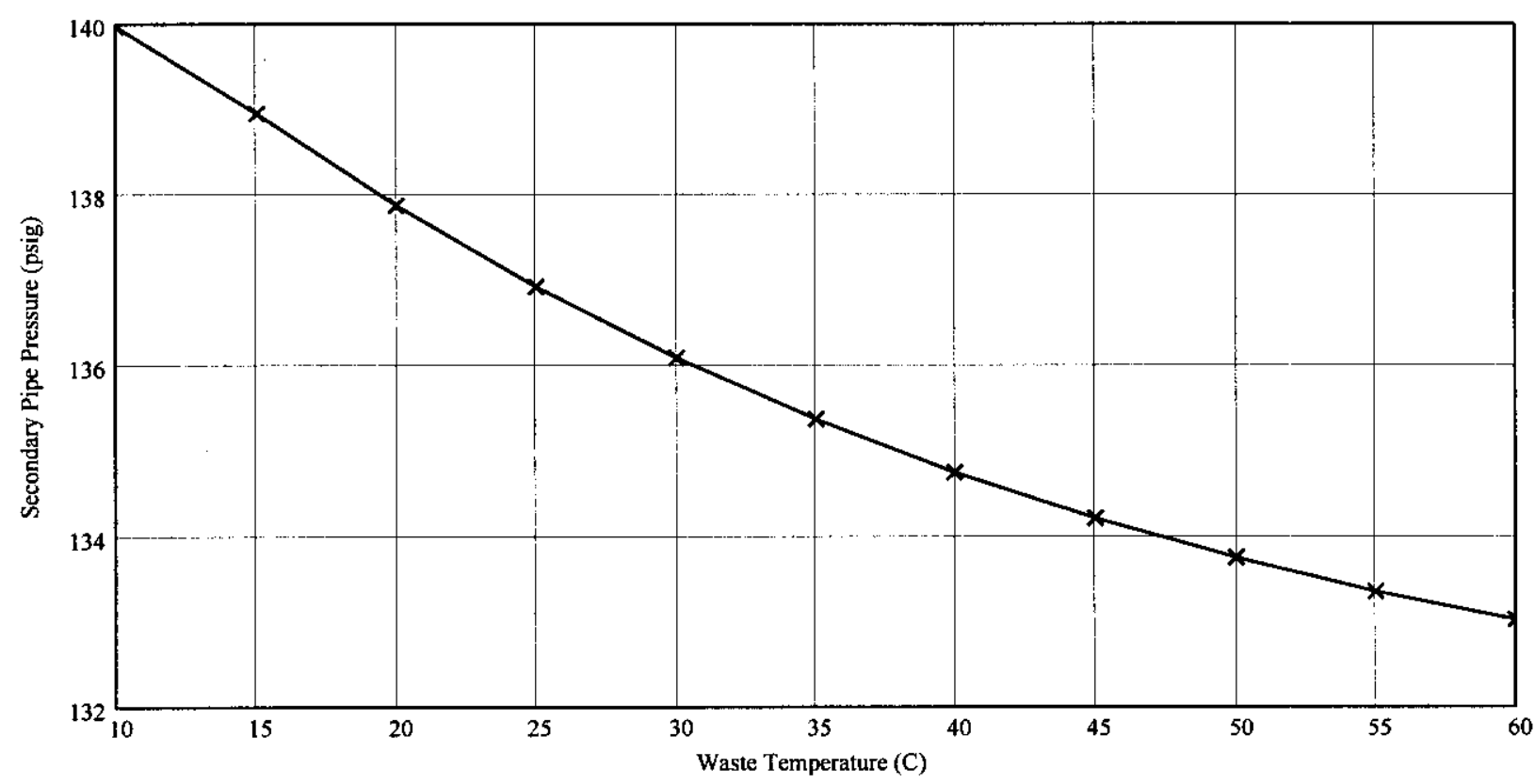




\section{CH2MHILL Hanford Group, Inc.}

\section{EVALUATION ANALYSIS}

Client: $\quad$ CH2M Hill Hanford Group, Inc.

Subject: Secondary Encasement Pipe Pressure Due to Primary Pipe Break in Waste Tank Transfer Piping System

Location: 200 Area - Hanford Site, Richland, Washington
Calc. No. RPP-LJJ-004

Revision: 0

Page No. 24 of 34

WO/Job No.

Date: $09 / \overline{07 / 2000}$

Checked: $09 / 08 / 2000$

Revised:

By:

\section{Effect of Waste Bulk Density}

$$
\begin{aligned}
& \rho \rho\left(L_{0}, L_{S}, x_{B}, \rho, t_{C}, p_{d h}, \varepsilon_{P}, \varepsilon_{S}, \varepsilon_{D}, D_{D i}, F_{D 6}, F_{D 9}, \Delta Z_{D}, L_{P}, H, Z, n\right):=\mid v p \leftarrow 0 \\
& \text { for } i \in 0 . . \text { length }(\rho)-1 \\
& \rho_{\mathrm{DD}} \leftarrow \rho_{\mathrm{i}} \\
& \mathrm{p} \leftarrow 0 \\
& \mathrm{p} \leftarrow \mathrm{ff}\left(\mathrm{L}_{\mathrm{o}}, \mathrm{L}_{\mathrm{S}}, \mathrm{x}_{\mathrm{B}}, \rho_{\mathrm{DD}}, \mathrm{t}_{\mathrm{C}}, \mathrm{p}_{\mathrm{dh}}, \varepsilon_{\mathrm{P}}, \varepsilon_{\mathrm{S}}, \varepsilon_{\mathrm{D}}, \mathrm{D}_{\mathrm{Di}}, \mathrm{F}_{\mathrm{D} 6}, \mathrm{~F}_{\mathrm{D} 9}, \Delta \mathrm{Z}_{\mathrm{D}}, \mathrm{L}_{\mathrm{f}}\right. \\
& \mathrm{vp}_{\mathrm{i}} \leftarrow \mathrm{p}_{\mathrm{n}, 0}
\end{aligned}
$$

Figure 6c. Pressure in Secondary Encasement Pipe as a Function of Waste Bulk Density Due to Primary Pipe Break at $x_{B}$ within Encasement Section with Two 1-in. Drains in

\section{Encasement Section of Length $L_{s}$ Starting at $L_{0}$ Relative to Pump.}

$$
\begin{aligned}
& \mathrm{Z}=25 \mathrm{ft} \quad \mathrm{p}_{\mathrm{dh}}=650 \mathrm{psi} \quad \mathrm{t}_{\mathrm{C}}=10^{\prime} \mathrm{C} \quad \varepsilon_{\mathrm{P}}=2 \mathrm{mil} \quad \varepsilon_{\mathrm{S}}=50 \mathrm{mil} \quad \varepsilon_{\mathrm{D}}=50 \mathrm{mil} \\
& \mathrm{H}=17.5 \mathrm{ft} \quad \mathrm{L}_{\mathrm{S}}=4000 \mathrm{ft} \quad \mathrm{L}_{\mathrm{o}}=0 \mathrm{ft} \quad \mathrm{L}_{\mathrm{p}}=7000 \mathrm{ft} \quad \mathrm{L}_{\mathrm{i}}=9 \mathrm{ft} \quad \mathrm{L}_{\mathrm{j}}=108 \mathrm{ft} \quad \mathrm{x}_{\mathrm{B}}=0 \mathrm{ft} \quad \mathrm{F}_{\mathrm{D} 6}=1 \\
& \Delta Z_{\mathrm{D}}=-1 \mathrm{ft} \quad \mathrm{D}_{\mathrm{Di}}=1.049 \text { in } \quad \mathrm{F}_{\mathrm{D} 9}=1 \\
& \mathrm{~L}_{\mathrm{D}}\left(\mathrm{D}_{\mathrm{Di}}\right)=10.9 \mathrm{ft}
\end{aligned}
$$

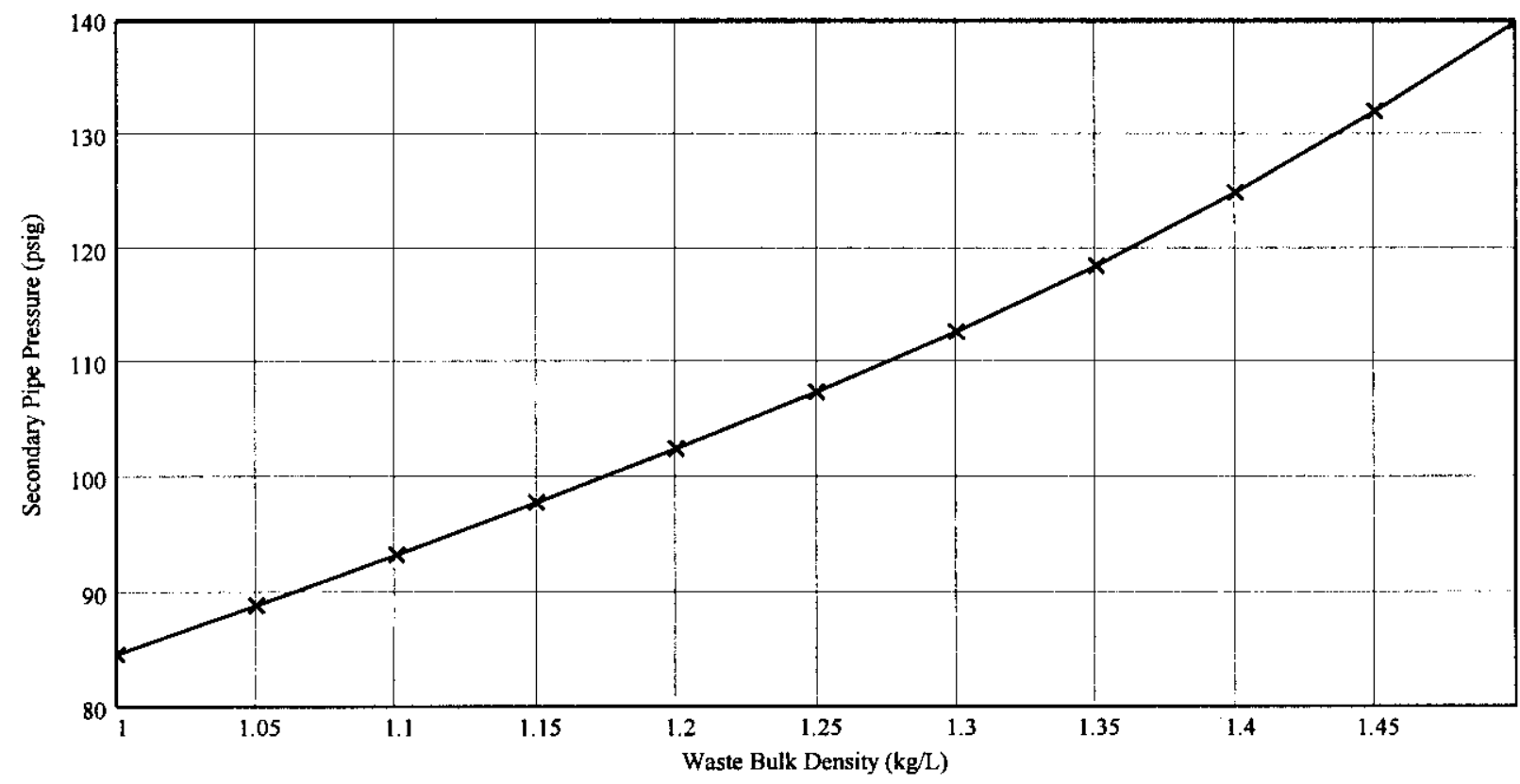


CH2MHILL Hanford Group, Inc.

RPP-6759 REV 0

EVALUATION ANALYSIS

Client: $\quad$ CH2M Hill Hanford Group, Inc.

Subject: Secondary Encasement Pipe Pressure Due to Primary Pipe

Break in Waste Tank Transfer Piping System

Location: 200 Area - Hanford Site, Richland, Washington
WO/Job No.

Date: $09 / \overline{07 / 2000}$ Checked: $09 / 08 / 2000$ Revised:
Calc. No. RPP-LJJ-004

Revision: $\underline{0}$

Page No. 25 of 34

\section{Low Point (One) Drain Case - Upward Sloping Pipe $(H>0)$ - 1-in. Drain}

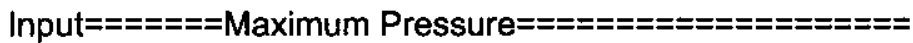

\begin{tabular}{|c|c|c|c|c|}
\hline $\mathrm{L}_{\mathrm{o}}:=0 \cdot \mathrm{ft}$ & $\mathrm{p}_{\mathrm{dh}}:=650 \cdot \mathrm{psi}$ & $\mathrm{H}=17.5 \mathrm{ft}$ & $\varepsilon_{\mathrm{P}}:=2 \cdot \mathrm{mil}$ & \\
\hline $\mathrm{L}_{\mathrm{S}}:=4000 \cdot \mathrm{ft}$ & $\rho:=1.5 \cdot \underline{\mathrm{kg}}$ & $\mathrm{Z}:=25 \cdot \mathrm{ft}$ & $\varepsilon_{\mathrm{S}}:=50 \cdot \mathrm{mil}$ & \\
\hline $\mathrm{L}_{\mathrm{P}}=7000 \mathrm{ft}$ & liter & $F_{D 6}:=1$ & $\varepsilon_{D}:=50 \cdot \mathrm{mil}$ & \\
\hline$x_{B}:=0 \cdot f t+L_{o}$ & $t_{C}:=10^{\circ} \mathrm{C}$ & $F_{D 9}:=0$ & $\mathrm{D}_{\mathrm{Di}}=1.049 \mathrm{in}$ & $\Delta Z_{D}=-1 \mathrm{ft}$ \\
\hline
\end{tabular}

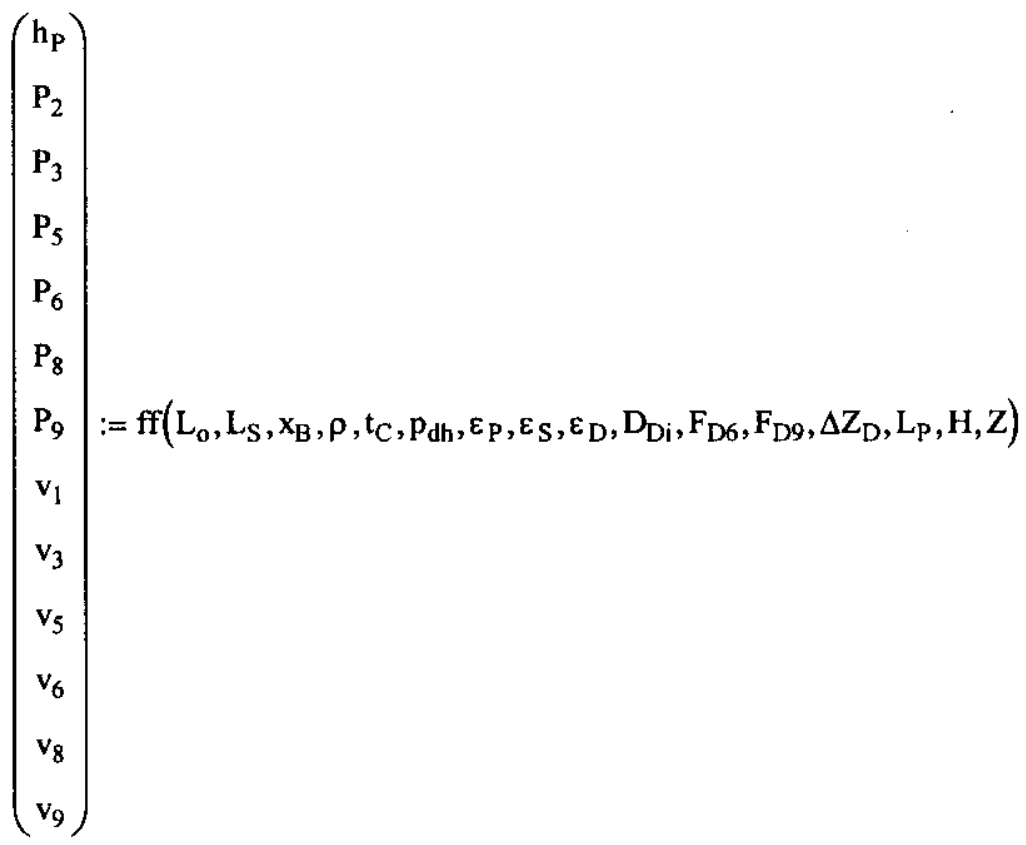

Results-

$$
\begin{aligned}
& h_{P}=340.7 \mathrm{ft} \quad H_{p}^{\prime}\left(A_{P} \cdot v_{1}, p_{d h}\right)=340.7 \mathrm{ft} \quad \mu_{t}:=\mu\left(\rho, t_{C}\right) \quad \mu_{t}=11.708 \mathrm{cP} \quad L_{i}=9 \mathrm{ft} \quad L_{j}=108 \mathrm{ft} \quad D_{D i}=1.049 \mathrm{in} \\
& P_{2}=221.5 \mathrm{psi} \quad \mathrm{v}_{1}=10.2 \mathrm{ft} \mathrm{sec}^{-1} \quad \mathrm{~A}_{\mathrm{P}} \cdot \mathrm{v}_{1}=234.7 \mathrm{gpm} \\
& P_{3}=222.3 \mathrm{psi} \quad \mathrm{v}_{3}=4.9 \mathrm{ftsec}^{-1} \quad A_{\mathrm{P}} \cdot \mathrm{v}_{3}=113.1 \mathrm{gpm} \\
& \frac{\varepsilon_{\mathrm{P}}}{\mathrm{D}_{\mathrm{Pi}}}=0.00065 \frac{\varepsilon_{\mathrm{S}}}{\mathrm{D}_{\mathrm{H}_{\text {_annulus }}}}=0.01949 \quad \frac{\varepsilon_{\mathrm{D}}}{\mathrm{D}_{\mathrm{Di}}}=0.04766 \\
& \mathrm{P}_{5}=222.5 \mathrm{psi} \\
& \mathrm{A}_{\mathrm{S}} \cdot \mathrm{v}_{5}=121.6 \mathrm{gpm} \\
& P_{6}=201.4 \text { psi } \quad v_{6}=45.1 \mathrm{ftsec}^{-1} \\
& F_{D 6} \cdot A_{f}\left(D_{D i}\right) \cdot v_{6}=121.6 \mathrm{gpm} \\
& \mathrm{v}_{8}=0 \mathrm{ftsec} \sin ^{-1} \\
& A_{\mathrm{S}} \cdot \mathrm{v}_{8}=0 \mathrm{gpm} \\
& \mathrm{F}_{\mathrm{D} 9} \cdot \mathrm{A}_{\mathrm{f}}\left(\mathrm{D}_{\mathrm{Di}}\right) \cdot \mathrm{v}_{9}=0 \mathrm{gpm} \\
& v_{1} \cdot A_{P}=A_{P} \cdot v_{3}+A_{S} \cdot v_{5}+A_{S} \cdot v_{8}=234.7 \mathrm{gpm} \\
& \text { (continuity check at break, OK) }
\end{aligned}
$$




\section{CH2MHILL Hanford Group, Inc.}

\section{EVALUATION ANALYSIS}

Client: $\quad$ CH2M Hill Hanford Group, Inc.

Subject: Secondary Encasement Pipe Pressure Due to Primary Pipe

Break in Waste Tank Transfer Piping System

Location: 200 Area - Hanford Site, Richland, Washington
Calc. No. RPP-LJJ-004

Revision: 0

Page No. 26 of 34
WO/Job No.

Date: $09 / \overline{07 / 2000}$

Checked: $09 / 08 / 2000$

Revised:
By: L. J. Julyk fy.

By: T.C. Oterneos

By:

Figure 7. Low Point (One) 1-in. Drain Case - Upward Sloping Pipe ( $\mathrm{H}>0$ )

Maximum Pressure in Secondary Encasement Pipe Due to Primary Pipe Break within Encasement Section with Low Point Drain in Encasement Section of Length $L_{s}$

Starting at $L_{o}=0 \mathrm{ft}$ Relative to Pump and for a Waste Temperature of $10^{\circ} \mathrm{C}$.

$\mathrm{Z}=25 \mathrm{ft} \quad \mathrm{p}_{\mathrm{dh}}=650 \mathrm{psi} \quad \rho=1.5 \frac{\mathrm{kg}}{\text { liter }} \quad \mu\left(\rho, \mathrm{t}_{\mathrm{C}}\right)=11.708 \mathrm{cP} \quad \varepsilon_{\mathrm{P}}=2 \mathrm{mil} \quad \varepsilon_{\mathrm{S}}=50 \mathrm{mil} \quad \varepsilon_{\mathrm{D}}=50 \mathrm{mil} \quad \mathrm{F}_{\mathrm{D} 6}=1$

$\mathrm{H}=17.5 \mathrm{ft} \quad \mathrm{t}_{\mathrm{C}}=10 \quad \mathrm{C} \quad \mathrm{L}_{\mathrm{o}}=0 \mathrm{ft} \quad \mathrm{L}_{\mathrm{P}}=7000 \mathrm{ft} \quad \mathrm{L}_{\mathrm{i}}=9 \mathrm{ft} \quad \mathrm{L}_{\mathrm{j}}=108 \mathrm{ft} \quad \mathrm{D}_{\mathrm{Di}}=1.049 \mathrm{in} \quad \mathrm{F}_{\mathrm{D} 9}=0$

$\Delta \mathrm{Z}_{\mathrm{D}}=-1 \mathrm{ft}$

$\mathrm{L}_{\mathrm{D}}\left(\mathrm{D}_{\mathrm{Di}}\right)=10.9 \mathrm{ft}$

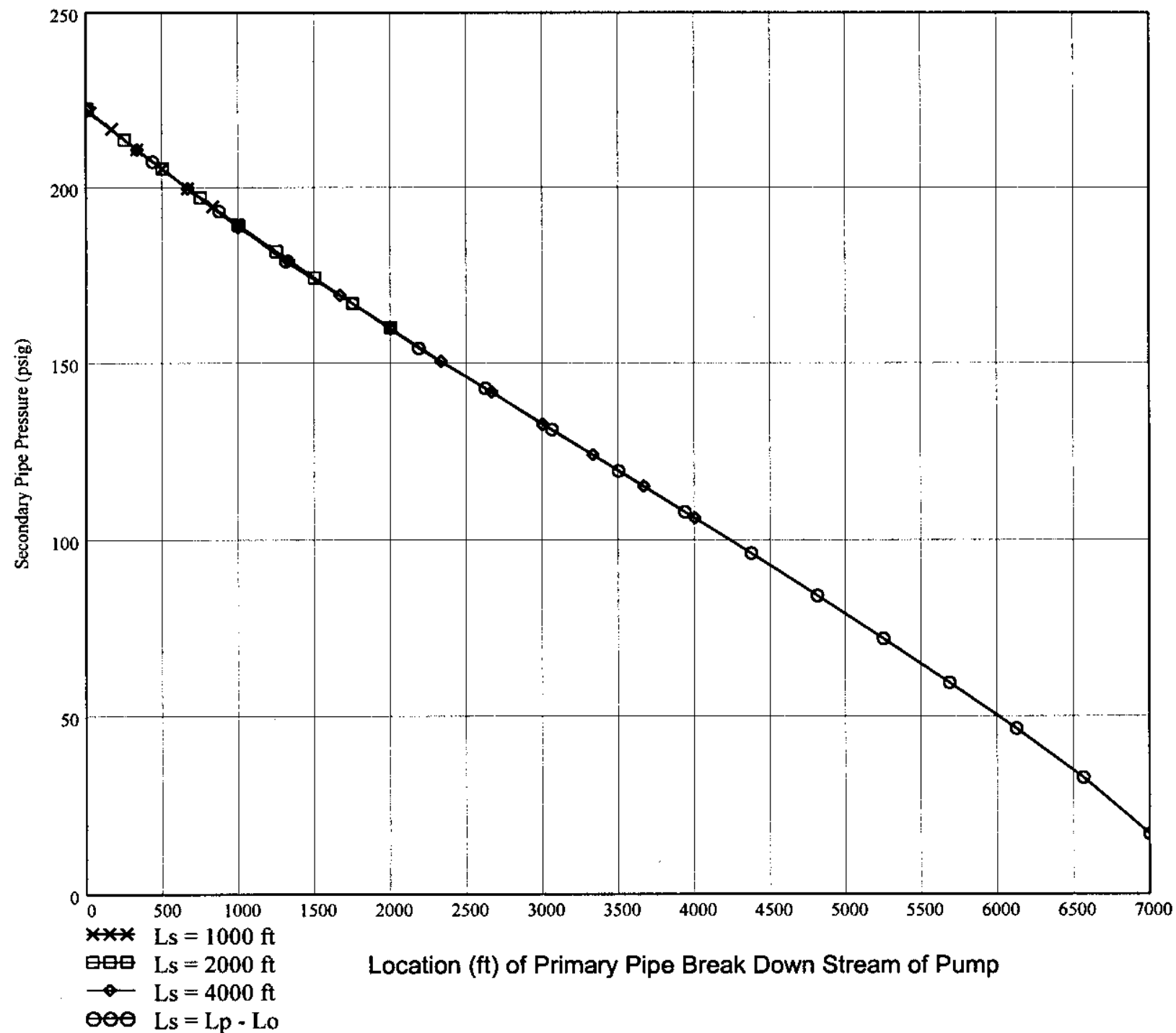




\section{CH2MHILL Hanford Group, Inc.}

\section{EVALUATION ANALYSIS}

Client: $\quad \mathrm{CH} 2 \mathrm{M}$ Hill Hanford Group, Inc.

Subject: Secondary Encasement Pipe Pressure Due to Primary Pipe Break in Waste Tank Transfer Piping System

Location: 200 Area-Hanford Site, Richland, Washington
RPP-6759 REV 0

Calc. No. RPP-LJJ-004

Revision: 0

Page No. -27 of 34

WO/Job No.

Date: $09 / \overline{07 / 2000}$ Checked: $09 / 08 / 2000$

Revised:
By: L. J. Julyk

By: T. C. Oten $-\infty$

By:

\section{Low Point (One) Drain Case - Downward Sloping Pipe $(\mathrm{H}<0)$ - 1-in. Drain}

Input=======Maximum Pressure===================="

$\mathrm{L}_{\mathrm{o}}:=0 \cdot \mathrm{ft}$

$\mathrm{L}_{\mathrm{S}}:=4000 \cdot \mathrm{ft}$

$\mathrm{L}_{\mathrm{P}}=7000 \mathrm{ft}$

$\mathrm{x}_{\mathrm{B}}:=0 \cdot \mathrm{ft}+\mathrm{L}_{\mathrm{o}}$

$$
p_{\mathrm{dh}}:=650 \cdot \mathrm{psi}
$$

$\mathrm{H}:=-0.25 \cdot \% \cdot \mathrm{L}_{\mathrm{p}}$

$\varepsilon_{\mathrm{P}}:=2 \cdot \mathrm{mil}$

$\rho:=1.5 \cdot \frac{\mathrm{kg}}{\text { liter }}$

$\mathrm{Z}:=25 \cdot \mathrm{ft}$

$\mathrm{F}_{\mathrm{D} 6}:=0$

$\mathrm{t}_{\mathrm{C}}:=10^{\circ} \mathrm{C}$

$\mathrm{F}_{\mathrm{D} 9}:=1$

$\mathrm{D}_{\mathrm{Di}}=1.049 \mathrm{in}$

$\varepsilon_{\mathrm{S}}:=50 \cdot \mathrm{mil}$

$\varepsilon_{\mathrm{D}}:=50 \cdot \mathrm{mil}$

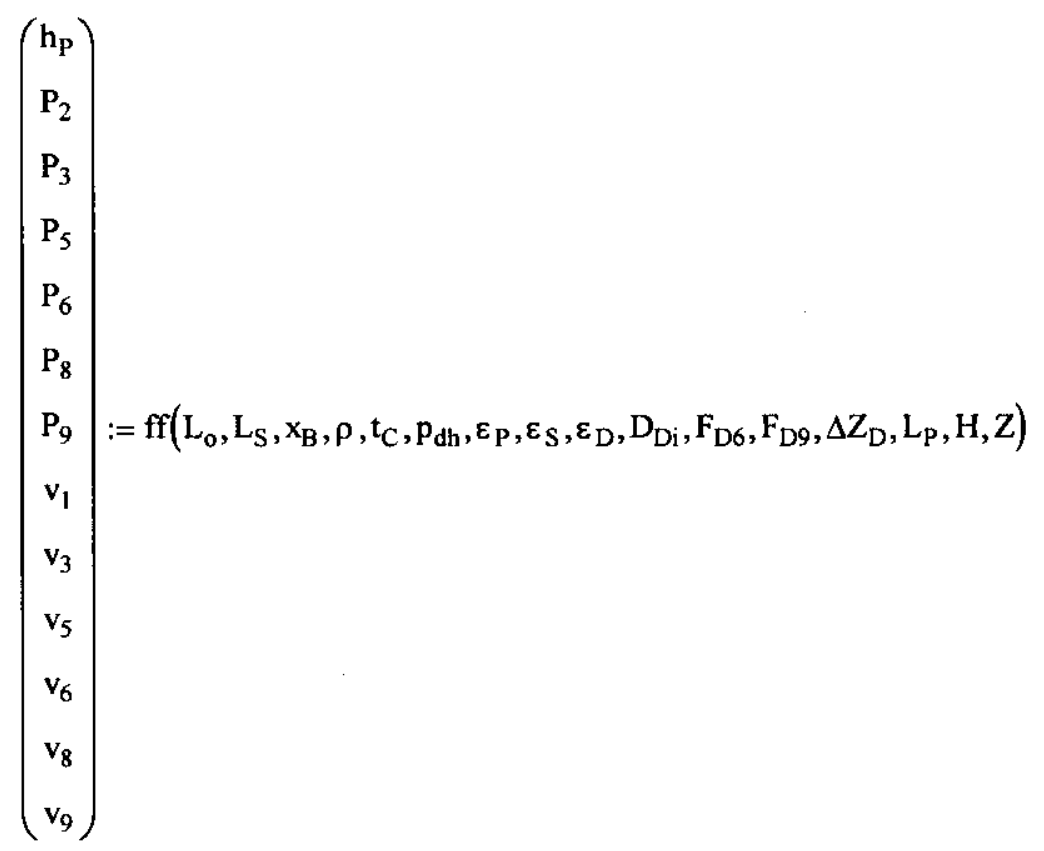

$\Delta \mathrm{Z}_{\mathrm{D}}=-1 \mathrm{ft}$

$L_{D}\left(D_{D i}\right)=10.9 f t$

Results-

$$
\begin{aligned}
& \mathrm{h}_{\mathrm{P}}=366.9 \mathrm{ft} \quad \mathrm{H}_{\mathrm{p}}^{\prime}\left(\mathrm{A}_{\mathrm{P}} \cdot \mathrm{v}_{\mathrm{l}}, \mathrm{p}_{\mathrm{dh}}\right)=366.9 \mathrm{ft} \quad \mu_{\mathrm{t}}:=\mu\left(\rho, \mathrm{t}_{\mathrm{C}}\right) \quad \mu_{\mathrm{t}}=11.708 \mathrm{cP} \quad \mathrm{L}_{\mathrm{i}}=9 \mathrm{ft} \quad \mathrm{L}_{\mathrm{j}}=108 \mathrm{ft} \quad \mathrm{D}_{\mathrm{Di}}=1.049 \mathrm{in} \\
& \mathrm{P}_{2}=238.6 \mathrm{psi} \quad \mathrm{v}_{1}=10 \mathrm{ft} \mathrm{sec}^{-1} \quad \mathrm{~A}_{\mathrm{P}} \cdot \mathrm{v}_{1}=230 \mathrm{gpm} \\
& P_{3}=239.3 \mathrm{psi} \quad \mathrm{v}_{3}=5.4 \mathrm{ft} \mathrm{sec}^{-1} \\
& \mathrm{v}_{5}=0 \mathrm{ft} \mathrm{sec}^{-1} \\
& A_{P} \cdot v_{3}=125.5 \mathrm{gpm} \\
& \frac{\varepsilon_{\mathrm{P}}}{D_{\mathrm{Pi}}}=0.00065 \\
& \frac{\varepsilon_{S}}{D_{H_{\text {annulus }}}}=0.01949 \\
& \frac{\varepsilon_{\mathrm{D}}}{\mathrm{D}_{\mathrm{Di}}}=0.04766 \\
& A_{S} \cdot v_{5}=0 \mathrm{gpm} \\
& \mathrm{F}_{\mathrm{D} 6} \cdot \mathrm{A}_{\mathrm{f}}\left(\mathrm{D}_{\mathrm{Di}}\right) \cdot \mathrm{v}_{6}=0 \mathrm{gpm} \\
& \mathrm{P}_{8}=239.6 \mathrm{psi} \quad \mathrm{v}_{8}=1.7 \mathrm{ft} \mathrm{sec}^{-1} \\
& \mathrm{~A}_{\mathrm{S}} \cdot \mathrm{v}_{8}=104.4 \mathrm{gpm} \\
& P_{9}=148.6 \mathrm{psi} \quad \mathrm{v}_{9}=38.8 \mathrm{ft} \mathrm{sec}^{-1} \\
& F_{D 9} \cdot A_{f}\left(D_{D i}\right) \cdot v_{9}=104.4 \mathrm{gpm} \\
& v_{1} \cdot A_{P}=A_{P} \cdot v_{3}+A_{S} \cdot v_{5}+A_{S} \cdot v_{8}=230 \mathrm{gpm} \\
& \text { (continuity check at break, OK) }
\end{aligned}
$$




\section{CH2MHILL Hanford Group, Inc.}

RPP-6759 REV 0

Client: $\quad$ CH2M Hill Hanford Group, Inc.

Subject: Secondary Encasement Pipe Pressure Due to Primary Pipe

Break in Waste Tank Transfer Piping System

Location: 200Area - Hanford Site, Richland, Washington

WO/Job No.

Date: $09 / \overline{07 / 2000}$ Checked: $09 / 08 / 2000$

Revised:
Calc. No. RPP-LJJ-004

Revision: 0

Page No. 28 of 34

By: L. J. Julyk

By: T. C. Oten rem

By:

$\mathrm{n}:=5$

Figure 8. Low Point (One) 1-in. Drain Case - Downward Slopping Pipe (H<0)

Maximum Pressure in Secondary Encasement Pipe Due to Primary Pipe Break

within Encasement Section with Low Point Drain in Encasement Section of Length $L_{s}$

Starting at $L_{o}=0 \mathrm{ft}$ Relative to Pump and for a Waste Temperature of $10^{\circ} \mathrm{C}$.

$\mathrm{Z}=25 \mathrm{ft} \quad \mathrm{p}_{\mathrm{dh}}=650 \mathrm{psi} \quad \rho=1.5 \frac{\mathrm{kg}}{\text { liter }} \quad \mu\left(\rho, \mathrm{t}_{\mathrm{C}}\right)=11.708 \mathrm{cP} \quad \varepsilon_{\mathrm{P}}=2 \mathrm{mil} \quad \varepsilon_{\mathrm{S}}=50 \mathrm{mil} \quad \varepsilon_{\mathrm{D}}=50 \mathrm{mil} \quad \mathrm{F}_{\mathrm{D} 6}=0$

$\mathrm{H}=-17.5 \mathrm{ft} \mathrm{t}_{\mathrm{C}}=10$ ' $\mathrm{C} \quad \mathrm{L}_{\mathrm{o}}=0 \mathrm{ft} \quad \mathrm{L}_{\mathrm{P}}=7000 \mathrm{ft} \quad \mathrm{L}_{\mathrm{i}}=9 \mathrm{ft} \quad \mathrm{L}_{\mathrm{j}}=108 \mathrm{ft} \quad \mathrm{D}_{\mathrm{Di}}=1.049$ in $\quad F_{\mathrm{D} 9}=1$

$\Delta \mathrm{Z}_{\mathrm{D}}=-1 \mathrm{ft}$

$\mathrm{L}_{\mathrm{D}}\left(\mathrm{D}_{\mathrm{Di}}\right)=10.9 \mathrm{ft}$

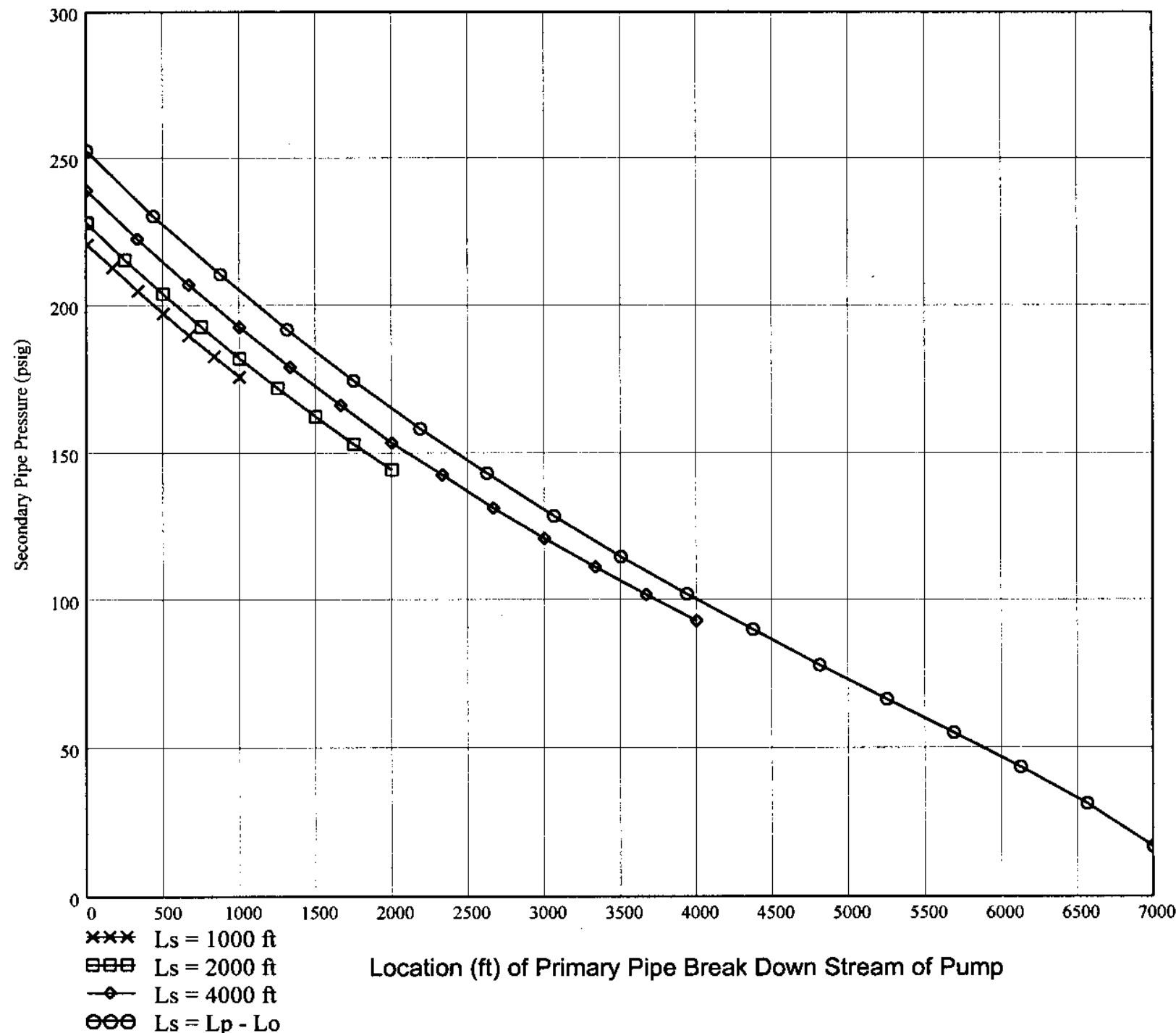




\section{CH2MHILL Hanford Group, Inc.}

\section{EVALUATION ANALYSIS}

Client: CH2M Hill Hanford Group, Inc.

Subject: Secondary Encasement Pipe Pressure Due to Primary Pipe Break in Waste Tank Transfer Piping System

Location: 200Area-Hanford Site, Richland, Washington
RPP-6759 REV 0

Calc. No. RPP-LJJ-004

Revision: 0

Page No. 29 of 34

WO/Job No.

Date: $09 / \overline{07 / 2000}$ Checked: $09 / 08 / 2000$ Revised:

\section{Two Drain Case - 2-in. Drain}

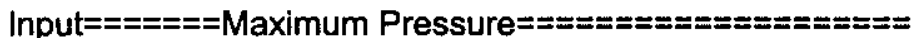

$$
\begin{array}{llll}
\mathrm{L}_{\mathrm{o}}:=0 \cdot \mathrm{ft} & \mathrm{p}_{\mathrm{dh}}:=650 \cdot \mathrm{psi} & \mathrm{H}=-17.5 \mathrm{ft} & \varepsilon_{\mathrm{P}}:=2 \cdot \mathrm{mil} \\
\mathrm{L}_{\mathrm{S}}:=4000 \cdot \mathrm{ft} & \rho:=1.5 \cdot \frac{\mathrm{kg}}{\text { liter }} & \mathrm{Z}:=25 \cdot \mathrm{ft} & \varepsilon_{\mathrm{S}}:=50 \cdot \mathrm{mil} \\
\mathrm{L}_{\mathrm{P}}:=7000 \cdot \mathrm{ft} & \mathrm{F}_{\mathrm{D} 6}:=1 & \varepsilon_{\mathrm{D}}:=50 \cdot \mathrm{mil} \\
\mathrm{X}_{\mathrm{B}}:=1333 \cdot \mathrm{ft}+\mathrm{L}_{\mathrm{o}} \quad \mathrm{t}_{\mathrm{C}}:=10^{\circ} \mathrm{C} & \mathrm{F}_{\mathrm{D} 9}:=1 & \mathrm{D}_{\mathrm{Di}}:=\mathrm{D}_{\mathrm{D} 2 \mathrm{i}} \quad \Delta \mathrm{Z}_{\mathrm{D}}=-1 \mathrm{ft} \quad \mathrm{L}_{\mathrm{D}}\left(\mathrm{D}_{\mathrm{Di}}\right)=18.5 \mathrm{ft}
\end{array}
$$

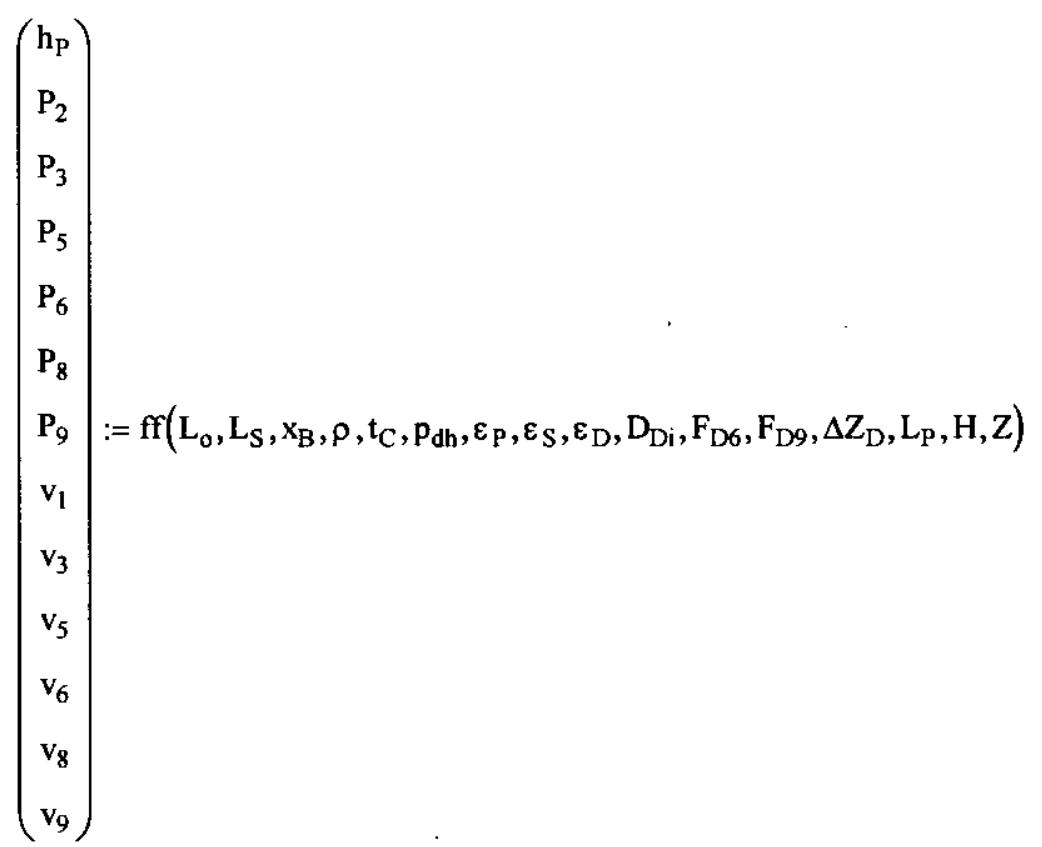

\section{Results}

$\mathrm{h}_{\mathrm{P}}=284.1 \mathrm{ft}$

$$
H_{p}\left(A_{P} \cdot v_{1}, p_{d h}\right)=284.1 \mathrm{ft}
$$

$\mu_{t}:=\mu\left(\rho, t_{C}\right)$

$\mu_{\mathrm{t}}=11.708 \mathrm{cP}$

$L_{i}=9 \mathrm{ft}$

$L_{j}=108 \mathrm{ft}$

$\mathrm{D}_{\mathrm{Di}}=2.067 \mathrm{in}$

$\mathrm{P}_{2}=39.1 \mathrm{psi}$

$v_{1}=10.6 \mathrm{ft} \mathrm{sec}^{-1}$

$A_{P} \cdot v_{1}=244.5 \mathrm{gpm}$

$\mathrm{P}_{3}=40.2 \mathrm{psi}$

$A_{P} \cdot v_{3}=46.3 \mathrm{gpm}$

$\frac{\varepsilon_{\mathrm{P}}}{\mathrm{D}_{\mathrm{Pi}}}=0.00065$

$\frac{\varepsilon_{S}}{D_{H_{-} \text {annulus }}}=0.01949$

$\frac{\varepsilon_{\mathrm{D}}}{\mathrm{D}_{\mathrm{Di}}}=0.02419$

$\mathrm{P}_{5}=40.2 \mathrm{psi}$

$A_{S} \cdot v_{5}=109.9 \mathrm{gpm}$

$\mathrm{P}_{6}=7 \mathrm{psi}$

$v_{5}=1.8 \mathrm{ftsec}^{-1}$

$\mathrm{F}_{\mathrm{D} 6} \cdot \mathrm{A}_{\mathrm{f}}\left(\mathrm{D}_{\mathrm{Di}}\right) \cdot \mathrm{v}_{6}=109.9 \mathrm{gpm}$

$\mathrm{P}_{8}=40.2 \mathrm{psi}$

$v_{6}=10.5 \mathrm{ft} \mathrm{sec}^{-1}$

$A_{S} \cdot v_{8}=88.3 \mathrm{gpm}$

$\mathrm{P}_{9}=4.3 \mathrm{psi}$

$v_{8}=1.5 \mathrm{ftsec}^{-1}$

$\mathrm{F}_{\mathrm{D} 9} \cdot \mathrm{A}_{\mathrm{f}}\left(\mathrm{D}_{\mathrm{Di}}\right) \cdot \mathrm{v}_{9}=\mathbf{8 8 . 3 \mathrm { gpm }}$

$$
v_{1} \cdot A_{P}=A_{P} \cdot v_{3}+A_{S} \cdot v_{5}+A_{S} \cdot v_{8}=244.5 \mathrm{gpm}
$$

(continuity check at break, $O K$ ) 


\section{CH2MHILL Hanford Group, Inc.}

\section{EVALUATION ANALYSIS}

Client: $\quad$ CH2M Hill Hanford Group, Inc.

Subject: Secondary Encasement Pipe Pressure Due to Primary Pipe Break in Waste Tank Transfer Piping System

Location: 200 Area - Hanford Site, Richland, Washington
Calc. No. RPP-LJJ-004

Revision: 0

Page No. 30 of 34
WO/Job No.

Date: $09 / 07 / 2000$

Checked: $09 / 08 / 2000$

Revised
Bंy: L. J. Julyk

By: T. C. Otern

By:

Figure 9. Maximum Pressure in Secondary Encasement Pipe Due to Primary Pipe Break within Encasement Section with Two 2-in. Drains in Encasement Section of Length $L_{s}$

Starting at $L_{o}=0 \mathrm{ft}$ Relative to Pump and for a Waste Temperature of $10^{\circ} \mathrm{C}$.

$$
\begin{aligned}
& \mathrm{Z}=25 \mathrm{ft} \quad \mathrm{p}_{\mathrm{dh}}=650 \mathrm{psi} \quad \rho=1.5 \frac{\mathrm{kg}}{\text { liter }} \quad \mu\left(\rho, \mathrm{t}_{\mathrm{C}}\right)=11.708 \mathrm{cP} \quad \varepsilon_{\mathrm{P}}=2 \mathrm{mil} \quad \varepsilon_{\mathrm{S}}=50 \mathrm{mil} \quad \varepsilon_{\mathrm{D}}=50 \mathrm{mil} \quad \mathrm{F}_{\mathrm{D} 6}=1 \\
& \mathrm{H}=-17.5 \mathrm{ft} \quad \mathrm{t}_{\mathrm{C}}=10 \quad \mathrm{c} \quad \mathrm{L}_{\mathrm{o}}=0 \mathrm{ft} \quad \mathrm{L}_{\mathrm{P}}=7000 \mathrm{ft} \quad \mathrm{L}_{\mathrm{i}}=9 \mathrm{ft} \quad \mathrm{L}_{\mathrm{j}}=108 \mathrm{ft} \quad \mathrm{D}_{\mathrm{Di}}=2.067 \text { in } \quad \mathrm{F}_{\mathrm{D} 9}=1 \\
& \Delta \mathrm{Z}_{\mathrm{D}}=-1 \mathrm{ft} \\
& \mathrm{L}_{\mathrm{D}}\left(\mathrm{D}_{\mathrm{Di}}\right)=18.5 \mathrm{ft}
\end{aligned}
$$

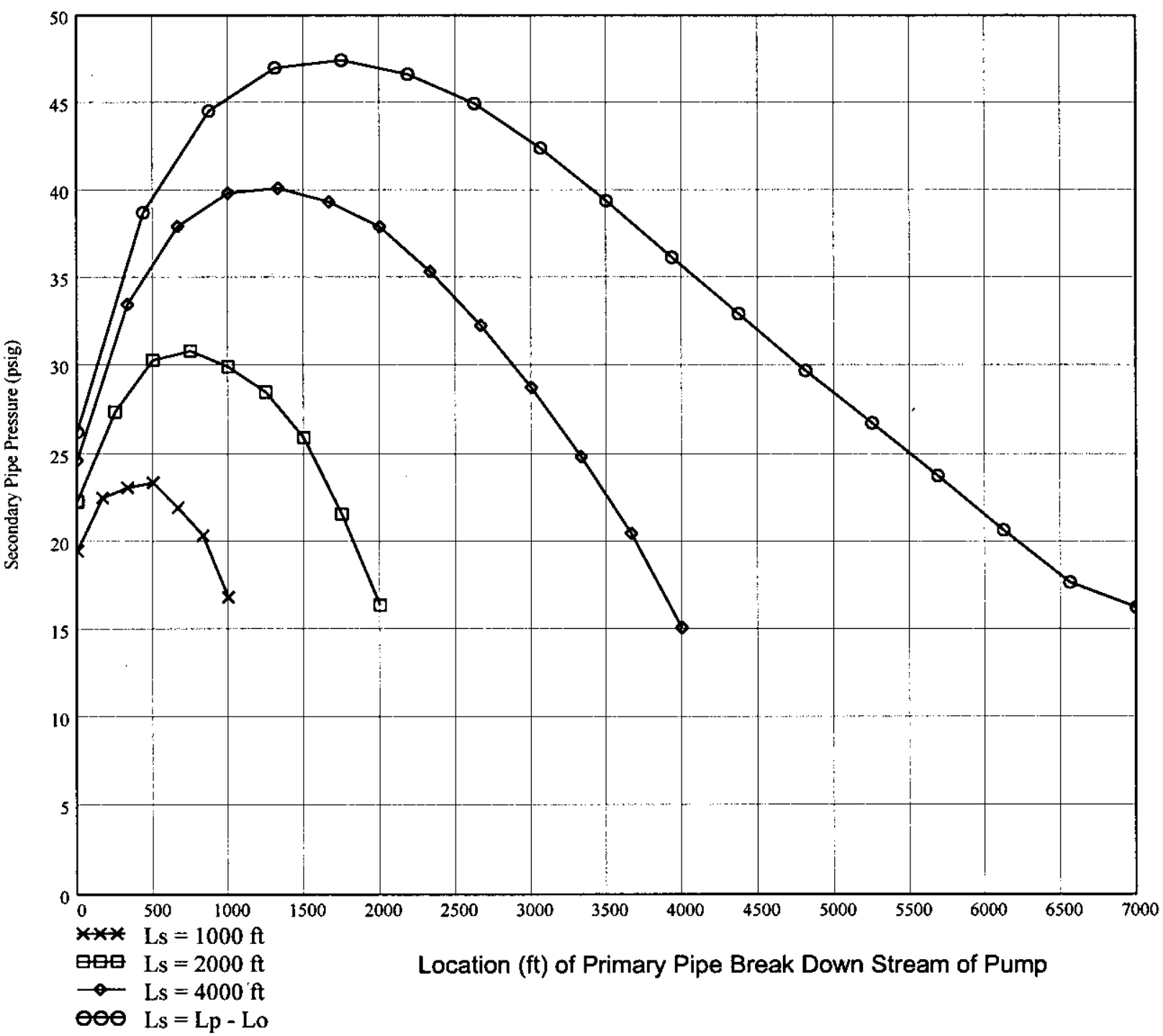


CH2MHILL Hanford Group, Inc.

\section{EVALUATION ANALYSIS}

Client: CH2M Hill Hanford Group, Inc.

Subject: Secondary Encasement Pipe Pressure Due to Primary Pipe Break in Waste Tank Transfer Piping System

Location: 200 Area-Hanford Site, Richland, Washington
$\mathrm{WO} /$ Job No.

Date: $09 / 07 / 2000$ Checked: $09 / 08 / 2000$ Revised:
Calc. No. RPP-LJJ-004

Revision: $\underline{0}$

Page No. 31 of 34

\section{Low Point (One) Drain Case - Upward Sloping Pipe (H>0) - 2-in. Drain}

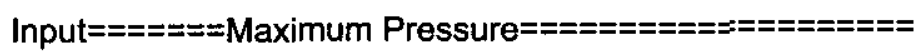

$$
\begin{array}{llll}
\mathrm{L}_{\mathrm{o}}:=0 \cdot \mathrm{ft} & \mathrm{P}_{\mathrm{dh}}:=650 \cdot \mathrm{psi} & \mathrm{H}=-17.5 \mathrm{ft} & \varepsilon_{\mathrm{P}}:=2 \cdot \mathrm{mil} \\
\mathrm{L}_{\mathrm{S}}:=4000 \cdot \mathrm{ft} \quad \rho:=1.5 \cdot \frac{\mathrm{kg}}{\mathrm{liter}} & \mathrm{Z}:=25 \cdot \mathrm{ft} & \varepsilon_{\mathrm{S}}:=50 \cdot \mathrm{mil} \\
\mathrm{L}_{\mathrm{P}}=7000 \mathrm{ft} & \mathrm{F}_{\mathrm{D} 6}:=1 & \varepsilon_{\mathrm{D}}:=50 \cdot \mathrm{mil} & \\
\mathrm{X}_{\mathrm{B}}:=2333 \cdot \mathrm{ft}+\mathrm{L}_{\mathrm{o}} \quad \mathrm{t}_{\mathrm{C}}:=10^{\circ} \mathrm{C} & \mathrm{F}_{\mathrm{D} 9}:=0 & \mathrm{D}_{\mathrm{Di}}=2.067 \mathrm{in} & \Delta \mathrm{Z}_{\mathrm{D}}=-1 \mathrm{ft} \quad \mathrm{L}_{\mathrm{D}}\left(\mathrm{D}_{\mathrm{Di}}\right)=18.5 \mathrm{ft}
\end{array}
$$

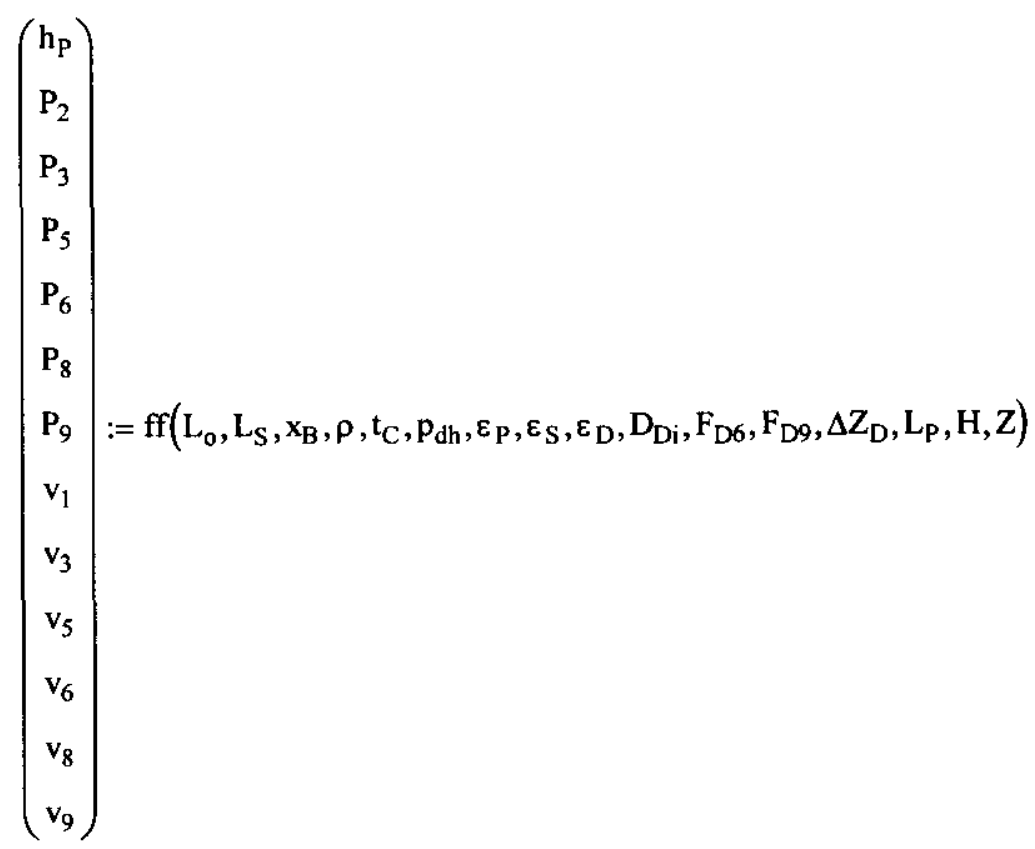

$$
\begin{aligned}
& \text { Results- } \\
& h_{p}=444.7 \mathrm{ft} \\
& \mathrm{H}_{\mathrm{p}}\left(\mathrm{A}_{\mathrm{P}} \cdot \mathrm{v}_{1}, \mathrm{p}_{\mathrm{dh}}\right)=444.7 \mathrm{ft} \\
& \mu_{t}:=\mu\left(\rho, t_{C}\right) \\
& \mu_{t}=11.708 \mathrm{cP} \\
& L_{i}=9 \mathrm{ft} \\
& \mathrm{L}_{\mathrm{j}}=108 \mathrm{ft} \\
& \mathrm{D}_{\mathrm{Di}}=2.067 \mathrm{in} \\
& \mathrm{P}_{2}=87.6 \mathrm{psi} \\
& \mathrm{v}_{1}=9.3 \mathrm{ft} \mathrm{sec}^{-1} \\
& A_{P} \cdot v_{1}=215.3 \mathrm{gpm} \\
& \mathrm{P}_{3}=88.3 \mathrm{psi} \\
& v_{3}=3.7 \mathrm{ft} \mathrm{sec}^{-1} \\
& A_{P} \cdot v_{3}=85.7 \mathrm{gpm} \\
& \frac{\varepsilon_{\mathrm{P}}}{\mathrm{D}_{\mathrm{Pi}}}=0.00065 \\
& \frac{\varepsilon_{\mathrm{S}}}{\mathrm{D}_{\mathrm{H}_{\text {annulus }}}}=0.01949 \\
& \frac{\varepsilon_{\mathrm{D}}}{\mathrm{D}_{\mathrm{Di}}}=0.02419 \\
& \mathrm{P}_{5}=88.4 \mathrm{psi} \\
& A_{S} \cdot v_{5}=129.6 \mathrm{gpm} \\
& P_{6}=10 \mathrm{psi} \\
& \mathrm{v}_{5}=2.2 \mathrm{ftsec}^{-1} \\
& \mathrm{~F}_{\mathrm{D} 6} \cdot \mathrm{A}_{\mathrm{f}}\left(\mathrm{D}_{\mathrm{Di}}\right) \cdot \mathrm{v}_{6}=129.6 \mathrm{gpm} \\
& v_{6}=12.4 \mathrm{ft} \mathrm{sec}^{-1} \\
& A_{S} \cdot v_{8}=0 \mathbf{g p m} \\
& \mathrm{F}_{\mathrm{D} 9} \cdot \mathrm{A}_{\mathrm{f}}\left(\mathrm{D}_{\mathrm{Di}}\right) \cdot \mathrm{v}_{9}=0 \mathrm{gpm} \\
& v_{1} \cdot A_{P}=A_{P} \cdot v_{3}+A_{S} \cdot v_{5}+A_{S} \cdot v_{8}=215.3 \mathrm{gpm} \\
& \text { (continuity check at break, } O K \text { ) }
\end{aligned}
$$




\section{CH2MHILL Hanford Group, Inc.}

\section{EVALUATION ANALYSIS}

Client: $\quad$ CH2M Hill Hanford Group, Inc.

Subject: Secondary Encasement Pipe Pressure Due to Primary Pipe Break in Waste Tank Transfer Piping System

Location: 200 Area - Hanford Site, Richland, Washington
Calc. No. RPP-LJJ-004

Revision: 0

Page No. 32 of 34

WO/Job No.

Date: $09 / 07 / 2000 \quad \dot{B} y:$ L. J. Julyk

Checked: $\frac{09 / 08 / 2000}{\text { By: T. C. Oten } r \infty}$

Revised

By:

Figure 10. Low Point (One) 2-in. Drain Case - Upward Sloping Pipe $(H>0)$

Maximum Pressure in Secondary Encasement Pipe Due to Primary Pipe Break

within Encasement Section with Low Point Drain in Encasement Section of Length $\mathrm{L}_{\mathrm{s}}$

Starting at $L_{o}=0 \mathrm{ft}$ Relative to Pump and for a Waste Temperature of $10^{\circ} \mathrm{C}$.

$$
\begin{aligned}
& \mathrm{Z}=25 \mathrm{ft} \quad \mathrm{p}_{\mathrm{dh}}=650 \mathrm{psi} \quad \rho=1.5 \frac{\mathrm{kg}}{\text { liter }} \quad \mu\left(\rho, \mathrm{t}_{\mathrm{C}}\right)=11.708 \mathrm{cP} \quad \varepsilon_{\mathrm{P}}=2 \mathrm{mil} \quad \varepsilon_{\mathrm{S}}=50 \mathrm{mil} \quad \varepsilon_{\mathrm{D}}=50 \mathrm{mil} \quad \mathrm{F}_{\mathrm{D} 6}=1 \\
& \mathrm{H}=-17.5 \mathrm{ft} \quad \mathrm{t}_{\mathrm{C}}=10^{\prime} \mathrm{C} \quad \mathrm{L}_{\mathrm{o}}=0 \mathrm{ft} \quad \mathrm{L}_{\mathrm{P}}=7000 \mathrm{ft} \quad \mathrm{L}_{\mathrm{i}}=9 \mathrm{ft} \quad \mathrm{L}_{\mathrm{j}}=108 \mathrm{ft} \quad \mathrm{D}_{\mathrm{Di}}=2.067 \text { in } \quad \mathrm{F}_{\mathrm{D} 9}=0 \\
& \Delta \mathrm{Z}_{\mathrm{D}}=-1 \mathrm{ft} \quad \mathrm{L}_{\mathrm{D}}\left(\mathrm{D}_{\mathrm{Di}}\right)=18.5 \mathrm{ft}
\end{aligned}
$$

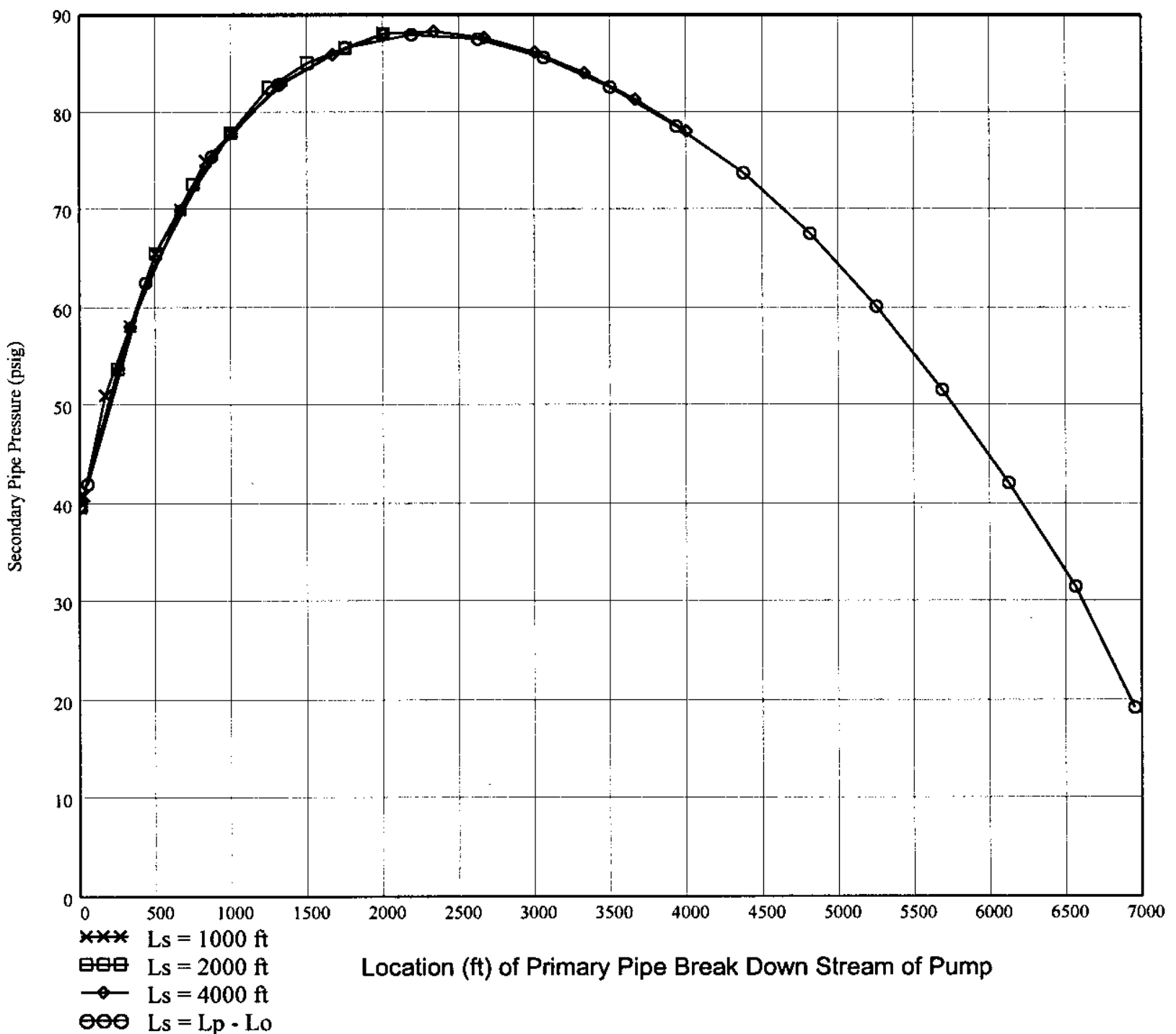




\section{CH2MHILL Hanford Group, Inc.}

\section{EVALUATION ANALYSIS}

Client: $\quad$ CH2M Hill Hanford Group, Inc.

Subject: Secondary Encasement Pipe Pressure Due to Primary Pipe Break in Waste Tank Transfer Piping System

Location: 200 Area - Hanford Site, Richland, Washington
RPP-6759 REV 0

Calc. No. RPP-LJJ-004

Revision: 0

Page No. 33 of 34

WO/Job No.

Date: $09 / \overline{07 / 2000}$ Checked: $09 / 08 / 2000$

Revised:
Bंy: L. J. Julyk

By: T. C. Oten 200

By:

\section{Low Point (One) Drain Case - Downward Sloping Pipe $(\mathrm{H}<0)$ - 2-in. Drain}

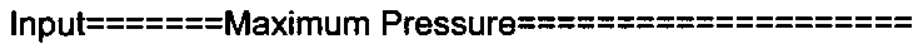

$\mathrm{L}_{\mathrm{o}}:=0 \cdot \mathrm{ft}$

$\mathrm{L}_{\mathrm{S}}:=4000 \cdot \mathrm{ft}$

$\mathrm{L}_{\mathrm{P}}=7000 \mathrm{ft}$

$\mathrm{x}_{\mathrm{B}}:=0 \cdot \mathrm{ft}+\mathrm{L}_{\mathrm{o}}$

$$
\begin{aligned}
& \mathrm{p}_{\mathrm{dh}}:=650 \cdot \mathrm{psi} \\
& \rho:=1.5 \cdot \frac{\mathrm{kg}}{\text { liter }}
\end{aligned}
$$$$
\mathrm{H}:=-0.25 \cdot \% \cdot \mathrm{L}_{\mathrm{P}}
$$$$
\varepsilon_{\mathrm{P}}:=2 \cdot \mathrm{mil}
$$$$
\mathrm{Z}:=25 \cdot \mathrm{ft}
$$$$
F_{D 6}:=0
$$$$
\mathrm{t}_{\mathrm{C}}:=10^{\circ} \mathrm{C}
$$

$\mathrm{F}_{\mathrm{D} 9}:=1$
$\varepsilon_{\mathrm{S}}:=50 \cdot \mathrm{mil}$

$\varepsilon_{\mathrm{D}}:=50 \cdot \mathrm{mil}$

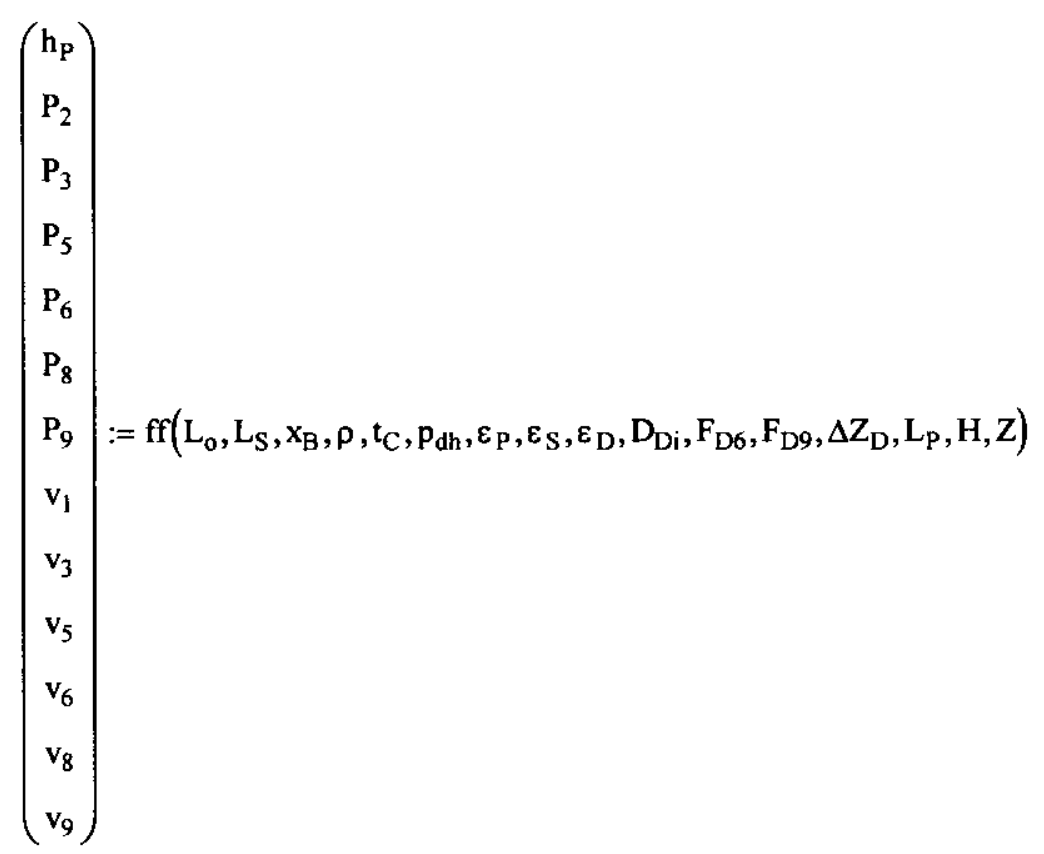

\section{Results}

$$
\begin{aligned}
& h_{P}=256.2 \mathrm{ft} \quad H_{p}^{\prime}\left(A_{P} \cdot v_{1}, p_{d h}\right)=256.2 \mathrm{ft} \quad \mu_{t}:=\mu\left(\rho, t_{C}\right) \quad \mu_{t}=11.708 \mathrm{cP} \quad L_{i}=9 \mathrm{ft} \quad L_{j}=108 \mathrm{ft} \quad D_{D i}=2.067 \text { in } \\
& P_{2}=166.6 \mathrm{psi} \quad \mathrm{v}_{1}=10.8 \mathrm{ftsec}^{-1} \quad A_{\mathrm{P}} \cdot \mathrm{v}_{1}=249.2 \mathrm{gpm} \\
& P_{3}=167.6 \mathrm{psi} \quad \mathrm{v}_{3}=4.4 \mathrm{ft} \mathrm{sec}^{-1} \\
& \mathrm{v}_{5}=-0 \mathrm{ft} \sec ^{-1} \\
& A_{\mathrm{P}} \cdot v_{3}=102.2 \mathrm{gpm} \\
& \frac{\varepsilon_{\mathrm{P}}}{\mathrm{D}_{\mathrm{Pi}}}=0.00065 \\
& \frac{\varepsilon_{\mathrm{S}}}{\mathrm{D}_{\mathrm{H} \_ \text {annulus }}}=0.01949 \\
& \frac{\varepsilon_{\mathrm{D}}}{\mathrm{D}_{\mathrm{Di}}}=0.02419 \\
& A_{S} \cdot v_{5}=-0 \mathrm{gpm} \\
& \mathrm{F}_{\mathrm{D} 6} \cdot \mathrm{A}_{\mathrm{f}}\left(\mathrm{D}_{\mathrm{Di}}\right) \cdot \mathrm{v}_{6}=0 \mathrm{gpm} \\
& P_{8}=167.7 \mathrm{psi} \quad \mathrm{v}_{8}=2.4 \mathrm{ft} \mathrm{sec}^{-1} \\
& A_{S} \cdot v_{8}=147 \mathrm{gpm} \\
& P_{9}=13 \text { psi } \\
& v_{9}=14.1 \mathrm{ft} \mathrm{sec}^{-1} \\
& F_{D 9} \cdot A_{f}\left(D_{D i}\right) \cdot v_{9}=147 \mathrm{gpm} \\
& v_{1} \cdot A_{P}=A_{P} \cdot v_{3}+A_{S} \cdot v_{5}+A_{S} \cdot v_{8}=249.2 \mathrm{gpm} \\
& \text { (continuity check at break, OK) }
\end{aligned}
$$


CH2MHILL Hanford Group, Inc.

\section{EVALUATION ANALYSIS}

Client: $\quad$ CH2M Hill Hanford Group, Inc.

Subject: Secondary Encasement Pipe Pressure Due to Primary Pipe Break in Waste Tank Transfer Piping System

Location: 200 Area-Hanford Site, Richland, Washington
WO/Job No.

Date: $09 / \overline{07 / 2000}$ Checked: $09 / 08 / 2000$

Revised:
Calc. No. RPP-LJJ-004

Revision: 0

Page No. 34 of 34

Figure 11. Low Point (One) 2-in. Drain Case - Downward Slopping Pipe $(\mathrm{H}<0)$

Maximum Pressure in Secondary Encasement Pipe Due to Primary Pipe Break within Encasement Section with Low Point Drain in Encasement Section of Length $L_{s}$

Starting at $L_{o}=0 \mathrm{ft}$ Relative to Pump and for a Waste Temperature of $10^{\circ} \mathrm{C}$.

$\mathrm{Z}=25 \mathrm{ft} \quad \mathrm{p}_{\mathrm{dh}}=650 \mathrm{psi} \quad \rho=1.5 \frac{\mathrm{kg}}{\text { liter }}$ $\mu\left(\rho, t_{C}\right)=11.708 \mathrm{cP}$ $\varepsilon_{\mathrm{P}}=2 \mathrm{mil}$ $\varepsilon_{\mathrm{S}}=50 \mathrm{mil}$ $\varepsilon_{\mathrm{D}}=50 \mathrm{mil}$ $\mathrm{F}_{\mathrm{D} 6}=0$

$\mathrm{H}=-17.5 \mathrm{ft}^{\mathrm{t}} \mathrm{t}_{\mathrm{C}}=10 \quad \mathrm{C} \quad \mathrm{L}_{\mathrm{o}}=0 \mathrm{ft}$

$\mathbf{L}_{\mathrm{P}}=7000 \mathrm{ft}$

$L_{i}=9 \mathrm{ft}$

$L_{j}=108 \mathrm{ft}$

$\mathrm{D}_{\mathrm{Di}}=2.067$ in

$\mathrm{F}_{\mathrm{D} 9}=1$

$\Delta \mathrm{Z}_{\mathrm{D}}=-1 \mathrm{ft}$

$\mathrm{L}_{\mathrm{D}}\left(\mathrm{D}_{\mathrm{Di}}\right)=18.5 \mathrm{ft}$

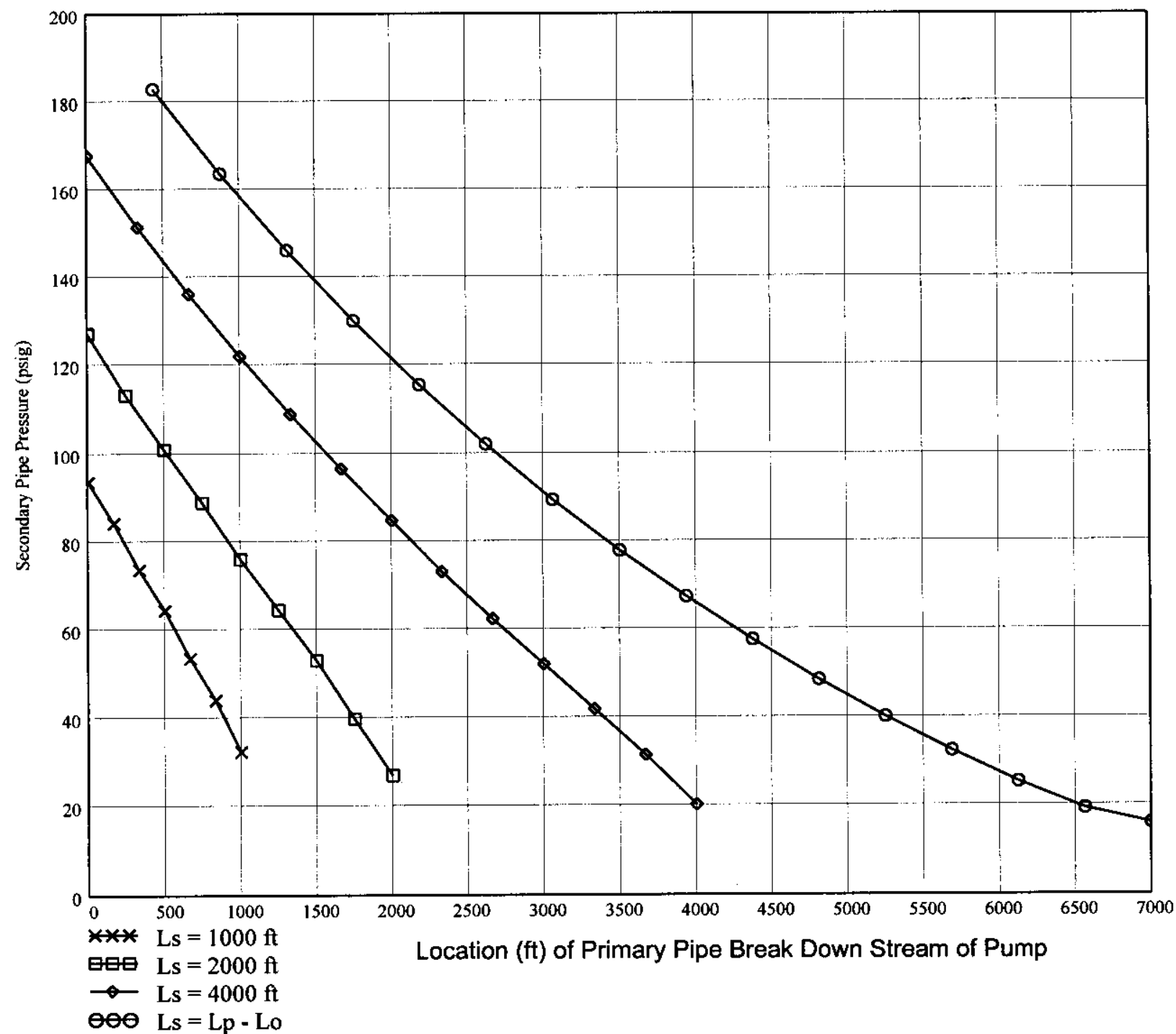

